\title{
Thrombotic tendency in young stroke patients : the thrombin potential as a screening parameter for coagulation disturbances
}

Citation for published version (APA):

Faber, C. G. (1998). Thrombotic tendency in young stroke patients : the thrombin potential as a screening parameter for coagulation disturbances. [Doctoral Thesis, Maastricht University]. Universiteit Maastricht. https://doi.org/10.26481/dis.19981204cf

Document status and date:

Published: 01/01/1998

DOI:

10.26481/dis.19981204cf

Document Version:

Publisher's PDF, also known as Version of record

Please check the document version of this publication:

- A submitted manuscript is the version of the article upon submission and before peer-review. There can be important differences between the submitted version and the official published version of record.

People interested in the research are advised to contact the author for the final version of the publication, or visit the DOI to the publisher's website.

- The final author version and the galley proof are versions of the publication after peer review.

- The final published version features the final layout of the paper including the volume, issue and page numbers.

Link to publication

\footnotetext{
General rights rights.

- You may freely distribute the URL identifying the publication in the public portal. please follow below link for the End User Agreement:

www.umlib.nl/taverne-license

Take down policy

If you believe that this document breaches copyright please contact us at:

repository@maastrichtuniversity.nl

providing details and we will investigate your claim.
}

Copyright and moral rights for the publications made accessible in the public portal are retained by the authors and/or other copyright owners and it is a condition of accessing publications that users recognise and abide by the legal requirements associated with these

- Users may download and print one copy of any publication from the public portal for the purpose of private study or research.

- You may not further distribute the material or use it for any profit-making activity or commercial gain

If the publication is distributed under the terms of Article $25 \mathrm{fa}$ of the Dutch Copyright Act, indicated by the "Taverne" license above, 
Thrombotic tendency in young stroke patients 
Cover/illustration: Magdalena Pelzer Manoeuvres in grijs en wit, $1995 / 1996$ Olieverf op doek, $122 \times 162 \mathrm{~cm}$.

The publication of this thesis was financially supported by: Boelhringer ingelheim Nederland, Nourypharma, Asta Medica, Yamanouchi Pharma.

Thrombotic tendency in young stroke patients: the thrombin potential as a screening parameler for coagulation disturbances C.G. Faber Thesis Universiteit Maastricht ISBN $90-9012009 \cdot 2$

NUGI 742

(1) 1998. C.G. Faber, Maastricht, The Nethertends

All rights are reserved, whether the whole of part of the materal is concerned No part of this publication may be reproduced, stoned in a retrieval system, or iransmitted in any form or by any means, electronic mechanical. photocopying, recording or otherwise, without witten permalssion from the copyright owner. 


\section{Thrombotic tendency in young stroke patients}

The thrombin potential as a screening parameter for coagulation disturbances

\section{PROEFSCHRIFT}

ter verkrijging van de graad van doctor aan de Universiteit Maastricht,

op gezag van de Rector Magnificus,

Prof. Dr. A. Nieuwenhuijzen Kruseman

volgens het besluit van het College van Decanen,

in het openbaar te verdedigen op

vrijdag 4 december 1998 om 12.00 uur

door

Catharina Gerritdina Faber 


\section{Promotores}

Protar. H. Hemker

Prot.dr. I. Troost

\section{Co-promotores}

Dr. S. Béguin

Dr. I. Lodder

\section{Beoordelingscommissie}

Prot.dr. H.F.P. Hillen (voorzitter)

Dr. J. Boiten

Prof dr. C. Haanen (Katholieke Universiteit Nimegen)

Dr. K. Hamulyák

Prof.dr. P.J Koudstaal (Erasmus Unversiteit Roterdam) 
People do not lack strength; they lack will

(Victor Hugo)

voor Henk en Thomas 



\section{Contents}

Abbreviations 9

General introduction

$1 \quad$ Introduction $\quad 15$

2 Enhanced red blood cell aggregation unrelated to fibrinogen: a passible stroke mechanism in young 31 patients

3. Thrombin generation in platelet poor plasma of young stroke patients

4 Thrombin generation in platelet rich plasma, platelel derived procoagulant activity, and won Willebrand lactor in young stroke patients

5 Influence of aspirin and fixed low-dose oral anticoagulation on thrombin generation in young stroke patients and in healthy volunteers

6 General discussion

7 Summary

$8 \quad$ Samenvalting

Relerences

Publications

Dankwoord

Curriculum Vitae 


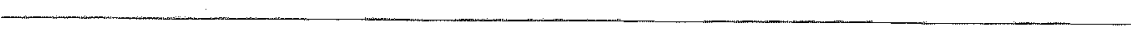




\section{Abbreviations}

$\begin{array}{ll}\text { APC } & \text { activated protein C } \\ \text { ESR } & \text { erythrocyte sedimentation rate } \\ \text { ETP } & \text { endogenous thrombin potential } \\ \text { GP } & \text { glycoprotein } \\ \text { INR } & \text { International Standardized Ratio } \\ \text { OR } & \text { odds ratio } \\ \text { PC } & \text { phosphatidyl choline } \\ \text { PE } & \text { phosphatidyl ethanolamine } \\ \text { PPP } & \text { platelet poor plasma } \\ \text { PPA } & \text { platelet derived procoagulant activity } \\ \text { PRP } & \text { platelet rich plasma } \\ \text { PS } & \text { phosphatidyl serine } \\ \text { RBCA } & \text { red blood cell aggregation } \\ \text { TF } & \text { tissue factor } \\ \text { TIA } & \text { transient ischaemic attack } \\ \text { TM } & \text { thrombomodulin } \\ \text { WWF } & \text { von willebrand factor }\end{array}$




$$
10
$$




\section{General introduction}

Stroke is the third leading cause of death and an important cause of longterm disability in most industrialised populations.' Stroke incidence rates strongly rise with age. Up to $10 \%$ of stroke patients is younger than 45 years. ${ }^{2}$ Especially stroke in young persons has dramatic consequences because permanent sequelae of stroke may remain for another 30 to 50 years. Moreover, it heavily burdens not only the patient, but also the partiner. family, and society in general. Approximately $60 \%$ of strokes in young patients are infarctions. ${ }^{34}$

The causes of ischaemic stroke in the young are diverse and consequently require a thorough diagnostic workup. Despite extensive investigations the cause of stroke remains uncertain in many young patients. This thesis is concerned with those causes that can be attributed to changes in haemorheology and haemostasis. In healthy persons a delicate balance exists between the coagulant and the anticoagulant system. This balance assures the fluidity of blood as well as adequale haemostasis. Stroke is one of the most dramatic signs of a disequilibrium of the coagulation system Haemorheologic factors, like red blood cell aggregation and blood viscosity, also influence blood flow. In 1990 a haematologic disorder or coagulopathy could be identified as the likely cause of stroke in only approximately $4 \%$ of young patients. ${ }^{5}$ Whether a coagulopathy is identified as a possible contributor to the development of stroke depends on the availability of valid tests that detect such disorders.

An enhanced erythrocyte aggregation is one of the possible causes of stroke. Enhanced red blood cell aggregation was correlated to librinogen plasma level, which in itself is a risk faclor for stroke. In chapler 2 we lested (1) whether erythrocyle aggregation is indeed enhanced in young stroke patients and (2) to what extent enhanced red blood cell aggregation is linked to fibrinogen.

The putative role of abnormalities of the clotting system suggests that screening for coagulation defects in young stroke patients may be usetul. Until recently a sensitive test of the overall haemostatic function of blood has been lacking because clotting times are not sensitive to hypercaagulability The clotting time does not reflect the amount of thrombin that will be formed. because clotting occurs as soon as $5-10 \mathrm{nM}$ of thrombin are formed, whereas thrombin generation continues until a peak of about $200 \mathrm{nM}$ is reached. Therefore, we have used a new assay, the thrombin polential, i.e. the area under the thrombin generation curve. The thrombin potential gives information on the coagulation system also in case of hypercoagulability and 
hence could be a useful screening parameter. With the use of the thrombin potential, patients with coagulation abnormalities could be identified, thereby limiting expensive further laboratory investigations to patients with an identified abnormality of overall function of the clotting system. To detect abnormalities in the plasmatic coagulation system we investigated the trrombin potential in platelet poor plasma. As mentioned above the haemostatic system is an equilibrium between the coagulant and the anticoagulant pathways. Therefore, we also investigated the role of the protein $\mathrm{C}$ pathway. We performed this by measurement of the thrombin polential in platelet poor plasma in the presence of thrombomodulin, which logether with thrombin activates protein $C$. Activated protein $C$ can inhibit activation of factor $V$ and factor Vill (chapter 3 ).

Apart from the plasmatic coagulation system, also platelets and von Willebrand factor are essential in thrombogenesis, among others via their role in thrombin formation. ${ }^{7}$ Comparing the thrombin potential in platelet rich plasma to that in platelet poor plasma allows distinction between hypercoagulability due to platelet abnormalities and plasma based hypercoagulability. Therefore, we investigated the thrombin potential in platelet rich plasma in young stroke patients and in controls. We Also measured the platelet derived procoagulant activity in serum, resulting from the activated platelet rich plasma. Recently, von Willebrand factor appeared a risk factor in the development of stroke. ${ }^{89}$ We therefore also measured the level of von Willebrand factor (chapter 4).

Up till now, most patients with ischaemic stroke of presumed arterial origin receive antiplatelet therapy (aspirin) as a means of secondary prevention However, the benefits are moderate. Aspirin administration in pallents with a prior stroke or transient ischaemic attack results in an absolute risk reduction in non-fatal stroke of $2 \%(8.2 \%$ in treated patients, $10.2 \%$ in controls), i.e. a relative risk reduction of $20 \%$. The alternative is oral anticoagulation. Highdose anticoagulants carry a substantial risk of adverse events . especially cerebral bleeding complications. "Therefore, high-dose anticoagulants are not indicaled in the prevention of non-cardioembolic stroke. Treatment with fixed low-dose oral anticoagulants lowered the risk of thromboembolic complications in some studies, but not in all. ${ }^{12-15}$ The use of oral anticoagulants at very low intensity might be an alternative in patients requiring long-term thrombosis prophylaxis. Such a regimen, if efficacious, might be associated with a lower bleeding risk than warfarin at standard intensity. It also might require less frequent laboratory moniloring. The thrombin potential is known to decrease with full oral anticoagulant therapy but the effect of low-dose aspirin and fixed low-dose anticoagulants is not therapy (aspirin) and fixed low-dose anticoagulants (phenprocoumon 0.75 
mg daily) on thrombin generation both in platelet rich plasma and in platelet poor plasma in young stroke patients and in healthy subjects (chapler 5 ).

\section{In summary:}

This thesis aims lo answer the following questions:

1. Do young stroke patients have an enhanced red blood cell aggregation compared to elderly stroke patients and to controls? (chapter 2)

2. Is red blood cell aggregation a risk factor for stroke independent of the fibrinogen concentration? (chapter 2)

3. Could we, by measuring the thrombin potential in platelet poor plasma, identify a subgroup of young stroke patients with hypercaagulability due to the plasmatic coagulation system? (chapter 3 )

4. Could we, by measuring the thrombin potential in platelet rich plasma, identify a subgroup of young stroke patients with hypercoagulability? (chapter 4)

5. Could we, by comparing thrombin generation in platelet rich plasma and in platelet poor plasma, identify a subgroup of patients with nypercoagulability due to platelet abnomalities? (chapter 4)

6. Do aspirin and fixed low-dose oral anticoagulants decrease thrombin generation in platelet rich plasma and/or in platelet poor plasma in young stroke patients and in healthy subjects? (chapter 5) 


$$
14
$$


Chapter

Ischaemic stroke in young patients erythrocyte aggregation platelet procoagulant activity and thrombin generation an introduction to this thesis 


\section{Ischaemic stroke in young patients}

In the hospital-based primary siroke centres of Lausanne and Maastricht. $12 \%$ and $8 \%$ of all patients with an ischaemic stroke were younger than 45 and 50 years, respectively. ${ }^{18}$ Of these young patients about two thirds presented with an infarct and one third with a transient ischaemic attack (TIA). Minor stroke and TIA patients do not differ in age, sex. vascular risk factors and underlying pathophysiology, whereas they have similar risks of future stroke or vascular death." Therefore, they can be considered together for the use of stroke research and clinical trials.

The causes of ischaemic stroke in young patients are more diverse than in elderly patients. The most common causes of ischaemic stroke in the young are listed in table 1.1 .18 Ischaemic stroke can be categorized by location, infarct size, clinical features and underlying stroke mechanism. Lacunar infarcts are attributed to small-wessel disease with local obstruction of a small perforating artery deep in the brain or brainstem, whereas large-vessel disease causes larger, often called territorial infarcts. In general, unusual causes of stroke are more frequent among young patients than among the elderly, in whom atheroscierosis is by tar the most trequent cause of ischaemic stroke. The prevalence of atherosclerosis increases with age. Overall, atherosclerosis has been considered to be the cause of stroke in 7 to $38 \%$ of patients younger than 50 years. Other frequent causes are arterial dissection and cardiogenic emboli. Despite extensive investigations, the cause of stroke remains uncertain in 7 to $56 \%$ of patients. ${ }^{2} 1618-22$ Unusual causes of stroke are more frequent in young patients with territorial stroke than in lacunar stroke. ${ }^{23}$

Until now, in up to a quarter of young patients with stroke, the major precipitant of brain ischaemia is a haematologic disorder or coagulopathy, ${ }^{524}$ ${ }^{25}$ In elderly patients atherosclerosis is the most frequent cause of stroke. Prethrombotic states may contribute to stroke in elderly patients as well. The coexistent atherosclerosis in these patients could obscure the rale of such a coagulopathy. A haematologic disorder, when identified after stroke, is not necessarily the cause of stroke, as it may be just a consequence. An antecedent haematologic disorder as a cause for stroke is more likely if it persists in the subsequent months following the ischaemic event. The state of the art in haematological research is such that many isolated causes of hypercoagulability can be demonstrated. Specific tests for these disorders are expensive and not readily available. Furthermore, they usually yield information only on a very small part of the coagulation system. Therefore, their sensitivity is rather low, which does not make them ideal to 'screen" for coagulation disorders in young stroke patients. 
Table 1.1. Causes of ischaemic stroke in patients less than 50 years of age

1. Atherosclerosis

2. Embolism

$10.30 \%$

a. Cardiac source

- valvular disease

- atrial fibrillation and sick sinus syndrome

- acute myocardial infarction and/or left

ventricular aneurysm

- Left atrial myxoma

- cardiomyopathy

b. Paradoxical embolism and puimonary source

- pulmonary arteriovenous mallormation

- alrial and ventricular septal defects with stunt

- patent roramen ovale with shunt

- pulmonary vein thrombosis

c. Other

- pulmonary and mediastinal tumors

- aortic cholesterol embolism

- transient embologenic aontitis

- emboli distal to unruptured aneurysm

- fat embolism syndrome

3. Arteropathy

$10-20 \%$

a. Inilammatory

- Takayasu's disease

- allergic and granulomalous

- infectious

b. Noninflammatory

- associated with systemic disease

- spontaneous dissections

- fibromuscullar dysplasia

- neck rauma

- Moya moya syndrome

- Familial: homocysteiruria, Fabry's pseudoxanthoma elasticum

4. Haematologic diseases and coagulopathies

a. Hyperviscosity

b. Coagulopathy

- polycythemia and myeloprolifartive disease

- dysprotenaemia

- thrombotic larombocytopenic purpura

- diffuse intravascular coegulation

- paroxysmal noctumal hemoglobulinuria

- oral contraceptive usel peripartumi pregnancy

- thrombocythaemia

- sickle cell disease

- hyperhomocysteinaemia?

- lupus anticoagulant?

- protein $\mathrm{C} / \mathrm{s}$ deficiency?

- APC-resistance?

- antithrombin Ifl deficiency?

- platelet hyperaggregability?

5. Small-vessel disease

6. Possibly
a. Migraine
b. Aicohol inioxication

7. Undetermined 
There are a number of haematologic abnomalities, that may be related 10 ischaemic stroke in the young

Deficiencies of coagulation inhibitors (antithrombin, protein $\mathrm{C}$, protein $\mathrm{S}$ and heparin colactor 11) could theoretically inchease arterial thrombosis. Yet, no convincing evidence is found for involvement of antithrombin-lly deficiency, of protein $C$ deficiency, of protein $S$ deficiency, and of activated protein $C$ resistance (factor $V$ Leiden) in the development of arterial thrombosis. 2326 However, recent data showed that young women with lactor $V$ Leiden mulation have an increased risk of myocardial infarction but only when other risk lactors are present (especially smoking). ${ }^{31}$ ?

Lupus anticoagulant and anticardiolipin antibodies are acquired immunoglobulins that are associated with thrombosis. These are closely related autoantibodies that react with proteins associated with phospholipid. Reported frequencies of antiphopholipid antibodies in patients with stroke vary widely: with a prevalence of 1110 . $50 \%{ }^{24}$ 33.38 A recent study in an unselected stroke population found no evidence to support the hypothesis that anticardiolipin antibodies are an independent risk factor for stroke in young people. 39 There was an increase in $\lg$ G titre with age and with the number of vascular risk factors, but the authors interpreted this as suggesting that anticardiolipin antibodies may be a nonspecific accompaniment of vascular disease. The overal contribution of antiphospholipid antibodies to the development of stroke therefore remains uncertain, but is probably very low

Oral contraceptives and pregnancy are considered another cerebrovascular risk. Data on oral contraceptives are conficting. Some authors did not find the overall risk of stroke to be increased among current users of low dose oestrogen oral contraceptives. whereas others described a small increase in relalive risk of occlusive stroke lor women of reproductive age who currently use oral contraceptives. The attributable risk, however, was very small. The high dose oestrogen pills carried a higher risk than the low dose pills. irespective of the type of progestin. The risk of cerebral

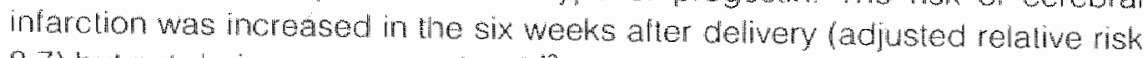
$8.7)$ but not during pregnancy itsel: ${ }^{2}$ ?

\section{Hyperhomocysteinaemia plays a role in the early onset of} atmerosclerosis. Homocysteine is produced by the demethylation of the essential amino acid methionine. It is catabolized by cysthationine B synthase. or is remethylated roming methionine, a reaction which in most lissues depends on the colactor activity of folale and witamin $\mathrm{B}_{12}$. defects result in severe hypenomocystemaemia, early onset of arteriosclerosis and frequent life-threatening thromboembolism. Severa studies showed that moderate typerhomocysteinaemia is common $(25-42 \%)$ in pallents with cerebrovascullar and cardiovascular disease. ${ }^{4}+$. The increase in homocysteine in mosi instances is probably due to cysthationine B-synthase deficiency. However, in a recent study no association of 
homocysteine concentration with ischaemic heart disease could be detected. ${ }^{51}$ Besides the possible atherogenic propensity, elevated homocysteine causes endothelial dysfunction. It enthances the aclivity of factor $\mathrm{VII}$ and factor $\mathrm{V}$, and induces the expression of tissue factor, ${ }^{5 ?}$ Homocysteine also inhibits activation of protein $\mathrm{C}$. both directly and by inactivating its vascular colactor thrombomodulin. ${ }^{\text {s.3 }}$ Uncomplicated hyperhomocysteinaemia is not accompanied by a rise in thrombin potential (Bos et al., personal communication). Vitamin supplementation decreases plasma homocysteine concentrations. However, the clinical efficacy on atherothrombogenesis is not (yet) known.

\section{Secondary prevention of stroke}

Antiplatelet therapy is clinically important, but has rather limited efficacy in the prevention of vascular events (stroke, myocardial intarction, or death from a vascular cause). Antiplatelet therapy in patients with a prior stroke or transient ischaemic attack (TIA) results in an absolute risk reduction in nonfatal stroke of $2 \%\left(8.2 \%\right.$ in treated patients, $10.2 \%$ in controls). ${ }^{1054}$ There has been some discussion on what dose of aspirin to use for the so-called secondary prevention of vascular events following TIA or stroke ${ }^{55}$ ss no dose-effect response has ever been demonstrated clinically, the dose in use depends on various factors. In the Netherlands most patients receive low dose aspirin treatment ( $30 \mathrm{mg}$ a day), because a Dutch study showed no significant difference in efficacy of $30 \mathrm{mg}$ or $283 \mathrm{mg}$ of aspirin. ${ }^{57}$

In a recent study in which aspirin and oral anticoagulation were compared in non-cardioembolic stroke, the odds of dying from a bleeding complication was 20 times higher in the anticoagulated group than in the group on aspirin Most of the bleedings were intracerebral haemorthages. "Standard dose oral anticoagulation has only been proven benelicial in patients with cardioembolic stroke. The use of oral anticoagulants at very low intensity represents an attractive alternative in patients requiring long-term thrombosis prophylaxis. At least it seems likely that such a regimen would be associalled with a lower bleeding risk than warfarin all standard intensity, and that it might also require less frequent laboratory monitoring. Trealment with fixed lowdose warfarin ( $1 \mathrm{mg} / \mathrm{day}$ ) reduced the incidence of deep vein thrombosis after major gynaecological surgery, ${ }^{12}{ }^{13}$ but the combination of aspirin and fixed low-dose warfarin had no additional effect over aspirin alone in patients after myocardial infarction..$^{15}$ Low-intensity warfarin (INP below 2.0) had no effect in the prevention of stroke in patients with non-theumalic alrial fibrillation. ${ }^{14}$ Recently, it was shown that most patients can be stably anticoagulated with very low doses of warlarin, and that such regimens generally result in the suppression of baseline $F_{1+2}$ levels, which is a marker 
of prothrombin activation, by approximately $50 \%$ and of lactor VIl coagulant activity

\section{Erythrocyte aggregation}

In states of no flow red cells in nomal blood spontaneously adhere to form rouleaux. The large plasma proteins, of which fibrinogen is the most important, are responsible for generaing the adhesive forces ${ }^{60}$ other macromolecules, such as a 2 macroglobulin and some immunoglobulins also contribute to red blood cell aggregation (RBCA) ${ }^{6.63}$ Erythrocyte aggregates that are morphologicaly diferent from rouleaux may also occur. Aggregates have an important influence on blood meology: they increase blood viscosity at low shear rates and are largely responsible for the so-called viscoelastic properties of blood. RBCA is thought to endow blood with a yield stress which may decrease microcirculatory flow. RBCA occurs in states of low shear stress and, unlike platelet aggregation, is usually reversible. The extent of aggregate formation depends on the nature and the concentration of aggregating proteins, plasma viscosity, erythrocyte delomability, and hematocit. RBCA is also influenced by erythrocyte surface charge densily. negatively charged phospholipids may be exposed with a transbilayer movement of phosphatidylserine under centain circumstances. 5566 In this way erylhrocytes, like platelets, may develop procaagulant activity.

Enhanced RBCA increases blood wiscosity in states of low shear rate diminishing blood passage through the cerebral capillary circulation. ${ }^{6}$ ar.ia Enhanced RBCA rather than hyperviscosily was responsible for the observed hypoxemic and reurologic symptomatology in an animal model ${ }^{\text {th }}$

Hematocrit and plesma fibrinogen concentration are negalvely associated with cerebral blood flow in stroke patients. ${ }^{33}$ Enhanced ABCA may be ome of the mechanisms to explain this finding. Several studies found enhenced RBCA in stroke patients. ${ }^{67 \% 38}$ There was a correlation belween fibrimogen concentration. platelet activalion and RBCA $\$$ " Erythrocytes can enhance platelel activity and FBCA may secondarily exacerbate platelet aggregation. Thrombospondin, one of the contents of the platelet $\alpha$ granules. may also induce eryhrocyte aggregation. ${ }^{8}$ Consequently. entranced FBCA could be caused by platelet activation.

\section{The coagulation mechanism}

Thrombin is the central enzyme in heemostasis and thrombosis. Any type of thrombosis is essentially caused by thrombin, in an intricate collaboration with platelets. Thrombin acts at the level of the plasma, the platelet and the vessel wall. It is the most potent platelet activator and activated platelets are crucial in causing explosive thrombin generation. Thrombin itself is not 
present in plasma, but can be formed by proteolytical cleavage of a precursor protein, prothrombin (iactor II).

Tissue injury brings damage to the endothelium of the vessel wal, thereby leading to exposure of tissue factor (TF) to the plasma proteins. This TF binds to factor VII(a). Probably there is always some circulating lactor VIla to start the reaction. The resulting TF-factor VII complex activates factor $X$ into factor Xa. Factor Xa catalyzes conversion of the TF-factor VII complex into the TF-factor Vlla complex, with a much higher enzymatic activity. ${ }^{83}$ In addition, the TF-factor Vila complex activates factor $\mid X^{84.96}$ which in lurn can also activate factor $X$ into $X a$.

Factor $X a$ alone can convert prothrombin into thrombin, although very slowly (less than $0.1 \%$ of the velocity of full prothrombinase). Small amounts of thrombin thus generated produce feedback reactions: activation of factor $V$ into $\mathrm{Va}:^{97}{ }^{86}$ of factor VIII into V/IIIa, ${ }^{89} 90$ and activation of platelets. Activaled platelets expose procoagulant phospholipids ${ }^{91}$ to which factor Va can bind. After binding, factor $V a$ serves as a platelet binding site for factor $\mathrm{Xa}$. For rapid, massive generation of thrombin the full complex Va-Xa-phospholipids (prothrombinase) is required.

Intrinsic

Extrinsic

pathway pathway

$y$

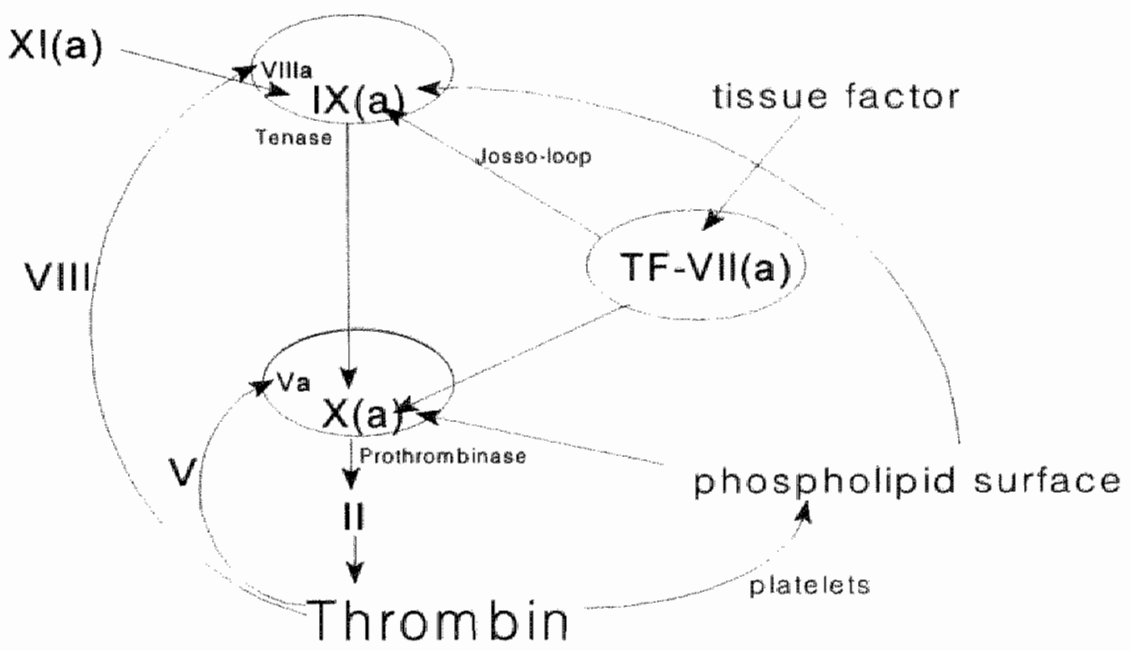

Figure 1.1. Sequence of actvation of plasma coagulation proteins 
Factor VIII circulates in the plasma attached to the very high molecular weight protein von Willebrand bactor (WWF). Thrombin splits ofl a part of lactor VIII, which causes the molecule to loose its affinity for WWF, after which it binds to phospholipids. Thereafler, factor Vllla-phospholipid complex binds lo tactor $\mathrm{Xa}$. The complex IXa-VIlla-phospholipids (tenase) is capable of activaling factor $X$, thus generating more prothrombinase. The formation of prothombinase and tenase leads to a burst of thrombin generation by converting prothrombin into thrombin.

Another way to initiate blood coagulation, is via the so called contact activation reactions ("intrinsic pathway"). When blood comes into contact with negatively charged surfaces (like gliass). facior XII "lactor Xl, prekallikrein and high molecular weight kininogen are activated, leading to activation of factor $X I$ into $X l a$, which in turn activates factor $K X$. From this point the intrinsic and the extrinsic pathway merge. The role of the intrinsic pathway under physiological conditions has not been unequivocally clarified. On the other hand, feedback activation of factor $X 1$ by thrombin seems to be required for full thrombin development in platelet rich plasma (Keularts et al, personal communication).

To balance between haemorhage and thrombosis thrombin formation has to be limited in space (see below) and in lime. Limitation in time occurs via two mechanisms: activated protein $\mathrm{C}$ and tissue factor pathway inhibitor. Thrombin can bind to thrombomodulin, a membrane protein, present at the surlace of intact endothelium. Thrombin adsorbs onto this protein and, in doing $\mathrm{so}$, looses its procoagulant properties and activales protein $\mathrm{C}$. Activated protein $\mathrm{C}$, together with its colactor protein $S$ can inactivate the lactors Va and VIlla, ${ }^{12}$ in this way inactivating both tenase and prothrombinase. This will reduce the formation of thrombin.

Another regulation mechanism operates via tissue faclor pathway inhibitor (TFPl), which binds 10 factor $X a^{94}$ The complex inhibits TF-factor vila complex. This mechanism ensures that lissue factor-induced factor $x$ activation will stop as soon as sulficient factor Xa is present.

Thrombin, once formed, is inactivaled by plasma protease inhibitors. (antithrombins) ${ }^{\circ}$ Antithrombin is the most important, contributing for $64 \%$ of tolal antithrombin aclivity, a2-macroglobulin accounts for $23 \%$, and the remaining $13 \%$ is taken care of by other antiproteases (mainly at. antitrypsin). ${ }^{909}$ The combined effect of these inhibitors makes the half life of thrombin in plasma 17 sec and that of (ree) factor $X a .80$ sec. Factor $X a$ in the prothrombinase complex is not alfected by these antiproteases.

All of these mechanisms participate in the inactivation of thrombin, thereby contributing to the balance between thrombin formation and thrombin inactivation. 


\section{Platelets}

The circulating platelet is a discoid cell, capable of very rapid responses to a range of physiological agonists (e.g. thrombin. collagen, ADP). On the platelet surface membrane glycoproteins (GP) are present, thal function as receptors for achesive proteins and physiological agonists. Collagen and thrombin are the primary, exogenous platelet activators. Fibrin also is a potent inducer of platelet procoagulant activily $(\text { fig } 1.2)^{\text {s. }}$

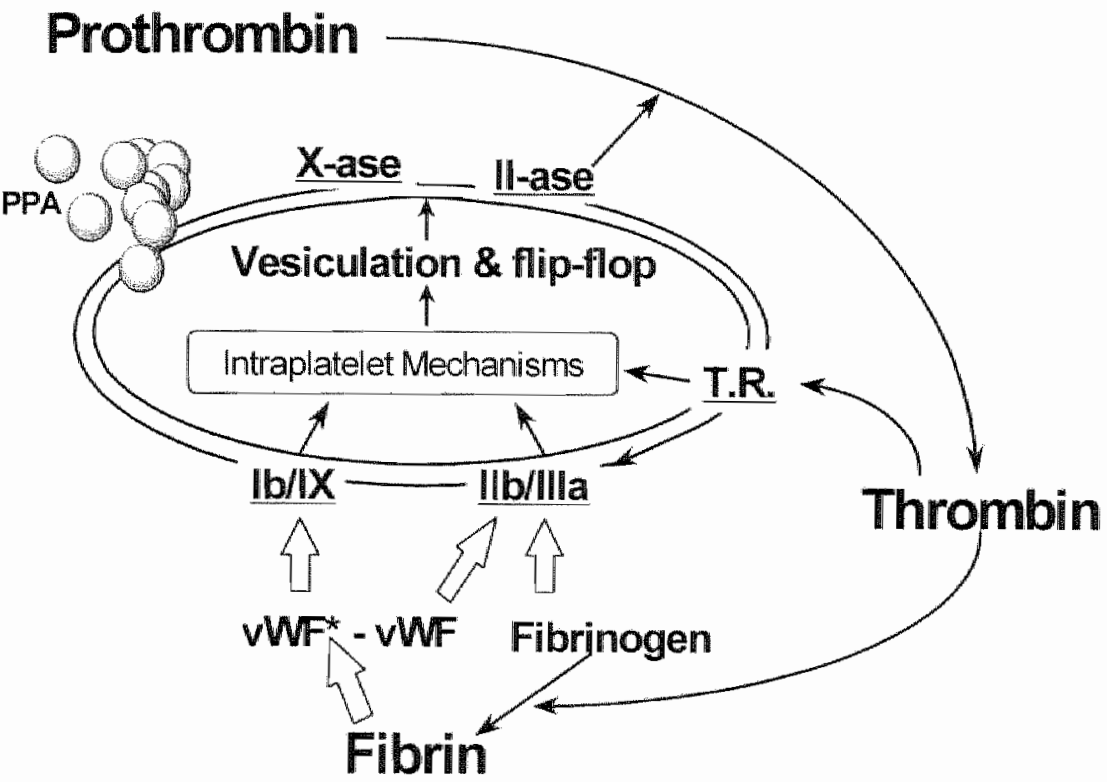

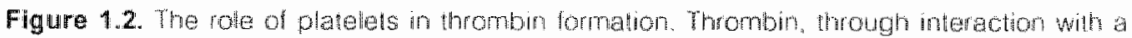

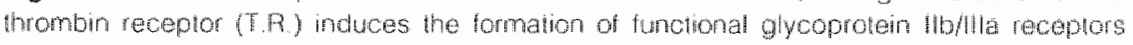

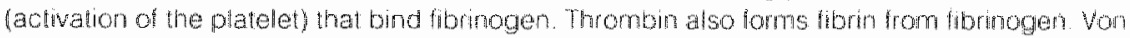

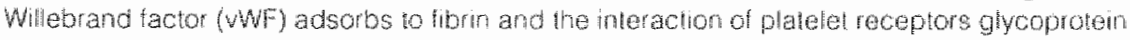

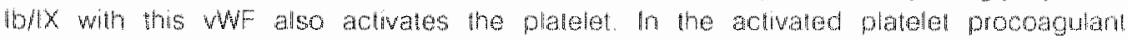
phospholipids become exposed. Aso procoaguant microvesictes ane shed from lhe platsht membrane: platelet derived procoagulam actwity (PPA) Prothombin achivation lakes place

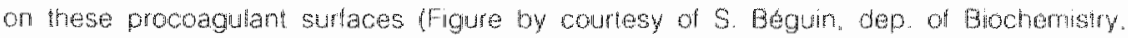
Uriversity of Matrich, The Neheriands)

The first phase of the haemostatic reaction is the adhesion of platelets to collagen in the exposed subendothelium of the vessel wall lesion. Platelets, bound to collagen, are readily activated by thrombin. Upon activation the platelet changes its shape from a smooth disc to a irregular sphere with extended pseudopods; in this way it can interact with other platelets. The 
platelet releases the contents of the $\alpha$-granules, which, among other things, contain factor $V$, fibrinogen, WWF, platelet factor 4 , and thrombospondin. One of the provoked platelet reactions is the so-called 'flip-flop' of the membrane. The procoagulant phospholipids phosphatidyl serine (PS) and phosphatidyl ethanolamine (PE) are almost entirely located at the inside of the platelet membrane. Collagen and thrombin induce a transbilayer movement of phospholipids in this membrane, ${ }^{66}$ resulting in an increased exposure of PS at the outer surface ${ }^{9100}$ Following activation platelets thus provide the procoagulant surface necessary for activation of factor $X$ and prothrombin. ${ }^{101}$

Another procoagulant reaction of the platelet membrane is the shedding of microvesicles. These phospholipid rich microvesicles expose PS at the outside and therefore can serve as a support for tenase and prothrombinase ${ }^{66} 1002103$ Also fibrin, even without thrombin being adsorbed to it, is a potent inducer of platelet procoagulant activity. ${ }^{98} 104$

Platelets adhere to collagen (in a wound) and fibrin (in a wound or ihrombus). Platelets attached to this matrix become procoagulant. Platelets do not adhere to intact vessel wall; in this way thrombin generation is limited in space.

A recently formed haemostatic plug is unstable until it is consolidated by a fibrin network, which requires thrombin generation. So thrombin serves both as fibrin-forming enzyme, and as platelet activator. There are many interactions between the platelet and the coagulation proteins, e.g.:

1. Thrombin causes a procoagulant reaction in the platelet membrane. The platelets thus activated, foster thrombin generation. ${ }^{92}$

2. Fibrinogen serves as adhesive platelet protein as well as thrombin substrate.

3. WWF acts as a carrier protein for factor VIII, is crucial for platelet adhesion to subendothelium, and plays an important role in the generation of thrombin in platelet rich plasma. ${ }^{105}$

\section{Fibrinogen}

Fibrinogen is present in plasma in a concentration of $2-3 \mathrm{~g} / /$, and in platelets (5-10\% of the plasma content). In infections and other inflammatory stales, the fibrinogen concentration in blood is elevated, most likely by increased synthesis. ${ }^{106}$

One of the effects of thrombin generation is the clotting of fibrinogen. Thrombin splits off two fibrinopeptides ( $A$ and $B$ ) from fibrinogen, and thus converts it into the fibrin monomer, which is the active form of fibrinogen. ${ }^{106}$ Fibrin monomers spontaneously polymerize to form long fibrin strands. Factor XIIla, activated by thrombin, also serves to crosslink the fibrin monomers to fibronectin and to crossink fibronectin to collagen. 
About 30-40\% of the thrombin generated in plasma is incorporated into the generated fibrin, limiting the activity of thrombin. ${ }^{\text {to }}$ Fibrinogen is required for platelet aggregation. The GPIb/lla complex on the platelet surface membrane has been identified as the platelet fibrinogen receptor. This complex only forms in activated platelets. Upon activation, the receptor undergoes divalent cation dependent contomational changes and expresses fibrinogen binding sites. ${ }^{109}$ The bound fibrinogen supports platelet aggregation by bridging adjacent platelets.

GPllb/llla can also serve as a receptor for fibronectin, WW and vitronectin. ${ }^{10-113}$ However, fibrinogen remains the chief ligand, possibly because it is the most abundant.

From several epidemiological studies fibrinogen concentration has emerged as an important and independent risk factor lor stroke and myocardial infarction. ${ }^{14-119}$ Among stroke survivors hyperfibrinogenaemia was found to be an independent risk factor for subsequent cardiowascular events. "120 Fibrinogen level also predicts the progression of atheroscterotic carotid stenosis. ${ }^{121}$ In addition, fibrinogen concentrations are elevated in the presence of other known cerebrowascular risk factors such as smoking, hypertension, hyperlipoproteinaemia or diabetes. ${ }^{22}$ Despite these associations fibrinogen concentration is an independen risk faclor for cerebrovascular disease.

The mechanisms by which fibrinogen may promote atherosclerosis and thrombosis are diverse. Apart from its role in haemostasis, fibrinogen is the major determinant of plasma viscosity and induces reversible red blood cell aggregation. Both phenomena limit the fluidity of blood. High levels of fibrinogen and a high hematocrit are negatively associated with cerebral blood flow" ${ }^{\text {rs }}$ but not in all studies. ${ }^{123}$ The haemorheologic consequences of hyperfibrinogenaemia might act at various levels: by reducing llow. by predisposing to thrombosis, and by entancing atherogenesis. ${ }^{124}$ Also, fibrin makes platelets procoagulant, and thus leads lo formation of more fibrin. This mechanism could possibly increase with higher fibrinogen, thus giving a novel explanation for the link between fibrinogen and stroke. Currently, a study is being done to investigate the effect of Ancrod" a defibrinating enzyme, on reduction of fibrinogen, and outcome in stroke patients.

\section{von Willebrand factor}

The WWF is a polymeric plasma glycoprotem, which is symthesized in megakaryocytes and endothelial cells. It is found in plasma, in the subendothelium and in the plattelet $\alpha$-granules. ${ }^{12}$

WW has three important functions in haemostasis:

1. It is the carrier for factor VIII, an essential cotactor in the generation of lactor Xa. ${ }^{126}$ 127 WF protects factor VIll from inactivation by actiwated 
proten $C$ or factor $X a$. If there is no circulating $W W F$ due to a congental deficiency, there is no factor VIII. Infusion of WWF without lactor VIll, makes lactor VIII appear. So WWF is an absolute requirement for the mainteriance of a normal level of factor VIII

2. The WF mediates platelet adhesion and aggregation. ${ }^{2}$ "It interacis with components of the subendothelium and with platelet receptors. The WWF promotes platelet interaction with the damaged vessell wall. ${ }^{\text {129-131 }}$ The irvolvement of WWF in mediating platelet adhesion and thrombus formation (i.e. platelet aggregation) is crucial under high shear stresses which are encountered in small vessels and stenosed arteries. Under conditions of high shear rates thrombus formation appeared to be more dependent on wW than on fibrinogen. ${ }^{32}$ WWF binds 10 endohelial components (e.g. collagem) that are exposed as a result of vessel injury. This adsorplion induces a conformational change in the WWF molecule by which it acquires the property to interact with the platelets. GPIb-llX complex, one of the glycoproteins present on the platelet membrane, mediates the adhesion of unstimulated platelets to WWF which is bound within the subendothelium of damaged vessels. ${ }^{133}$ 134 The WW can also bind to GPllb/lla receptors. ${ }^{134}$ This binding plays a role in platelet aggregation. ${ }^{135}$ The WWF also mediates binding of platelets to fibrim through GPlb. ${ }^{104} 136-138$

3. A role of WWF recently discovered is that as a necessary mediator in the mechanism that brings out procoagulant activity in platelets. Thrombin induces platelet procoagulant activity in a GPllb/lla dependent process. Fibrin requires GPlb for making the platelet procoagulant. WWF is a necessary cofactor in bolln mechanisms. " in:4 Inhibition of WWF or severe WWF deficiency prevents thrombin generation in platelet rich plasma almost completely. ${ }^{105}$

Several studies found a correlation beween high levels of WWF and cerebrovascular disease. is 139 Calto also found a relationship between WWF, stroke morlality and stroke type. Previously. we lound an elevation in WWF both in young stroke patients and in elderly stroke patients compared to controls. Elderly patients, however, had a much higher wF concentration than young patienls did (unpublished observation). This could be due to more extended endothelial damage related to large vessel atherosclerotic disease, which is more common in elderly than in young patients. As mentioned earlier however. WW is not merely a marker of endothelial damage, but it also plays an active role in atherothrombogenesis. " Since WWF is important in developing platelet procoagulant activity, one can wel imagine its possible role in adverse clinical events.

Plasma concentration of WWF is related to a number of other stroke risk factors, including smoking, hypertension, hyperhomocysteinaemia and diabeles. ${ }^{2}-145$ There is controversy about the relation belween WWF and age ${ }^{143}$ wike fibrinogen, WWF also is an acute phase reactant. 


\section{Thrombin generation}

The enzymatic action of thrombin on a large number of substrates, and its role as inducer of the procoagulant effect in platelets is essential in haemostasis and thrombosis. The rise and fall of thrombin concentration after triggering coagulation in plasma results from the combined activity of the prothrombin activating enzyme prothrombinase and the thrombin inactivating processes, i.e. the binding of thrombin by antithrombins, such as antithrombin and $\alpha 2$-macroglobulin. The thrombin generation curve is one of the oldest tools of the coagulation trade. It is the basis of the so-called iwostage prothrombin estimation. ${ }^{147-149}$ A typical thrombin generation curve is characterised by a lag-phase after which a burst of thrombin is seen that disappears due to the action of the natural antithrombins (fig. 1.3). Hemker and Béguin introduced the so-called endogenous thrombin potential (ETP), the area under the thrombin generation curve. This variable is the product of thrombin concentration, and the time that it acts. ${ }^{977} 150$ It indicates how much substrate the thrombin generated in plasma can polentially convert. They also developed a method that allows a quantitative spectrophotometric measurement of thrombin generation, and hence of the ETP, both in platelet rich plasma and in platelet poor plasma. ${ }^{151}$ The ETP gives information on the coagulation system as a whole, i.e. on the numerous pathways in which many positive and negative feedback loops interact. Consequently, measuring the ETP both in platelet rich plasma and in platelet poor plasma makes it possible to distinguish between the role of the platelets in interaction with the plasmatic coagulation proteins and the role of the plasmatic coagulation system.

\section{Thrombin potential in platelet rich plasma}

Thrombin formation and platelet activation are intimately linked in haemostasis and thrombosis. Thrombin can not be formed in wivo unless activated platelets expose their procoagukant phospholipid surface. whereas platelets thave to be activaled first by thrombin itself. Thrombin generation can be assessed in platelet rich plasma or whole blood. In this way, the interplay between blood platelets and the plasmatic coagulation factors under in vitro conditions that approach the in vivo conditions can be imvestigated. ${ }^{152}$ Under these experimental circumstances procoagulant phospholipids are the rate limiting factor for thrombin generation and not the factors $V$ or VIII. ${ }^{\text {i51 }}$ Therefore, the moment of the burst of thrombin generation is the moment at which the platelets massively expose their procoagulant surface. The lag-phase can be shorlened by adding a low amount of thrombin. 


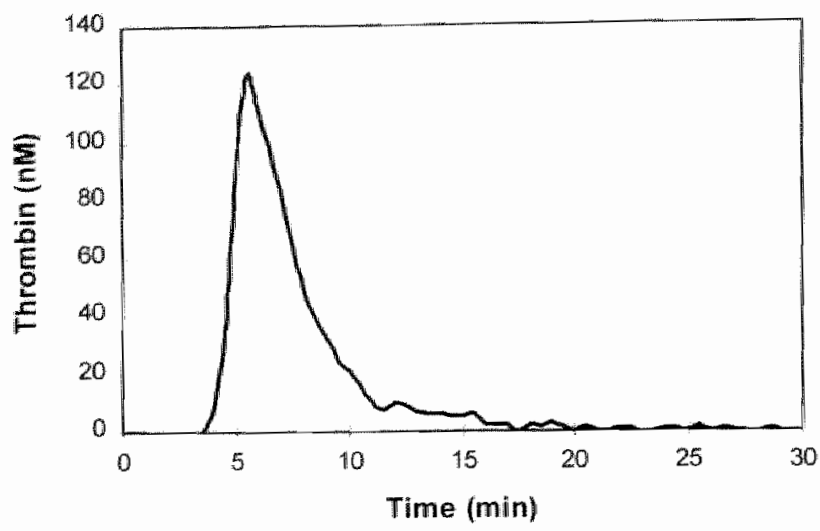

Figure 1.3. The thrombin generation curve in platelet rich plasma.

The course of events in vitro is as follows: freshly prepared platelet rich plasma is to be regarded as platelet poor plasma in which unactivated, hence non-procoagulant platelets are suspended. Coagulation is triggered by calcium in combination with a low concentration of tissue factor. Tissue factor induces the formation of small amounts of thrombin to be formed, which act on the platelets, that in this way will become activated. Once platelet activation reaches a (low) threshold value, thrombin generation accelerates, the platelets are activated en masse and provide the phospholipids that allows explosive thrombin generation, up to about 120 $\mathrm{nM}$.

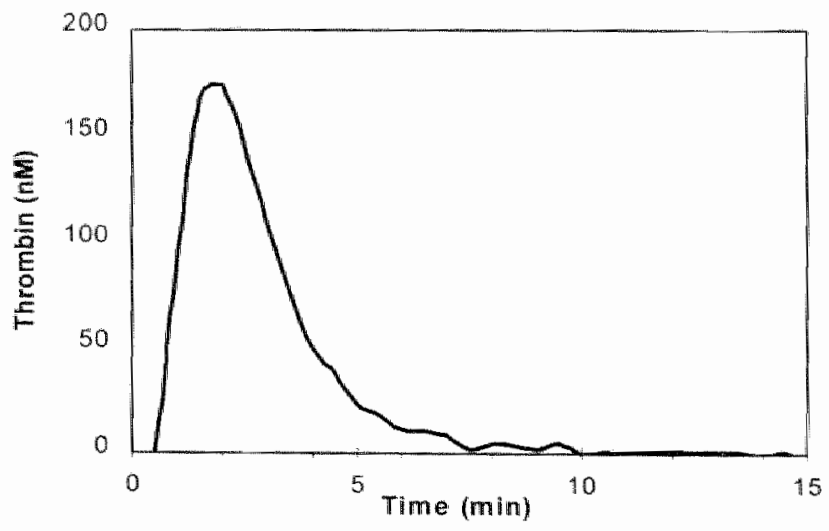

Figure 1.4. The thrombin generation curve in platelet poor plasma 
All antithrombotic medication that has proven to be active, ie. heparin. oral anticoagulation and aspirin, cause an inhibition of the cooperative effect between platelets and thrombin, which is reflected in a prolongation of the lag-phase and a decrease of the ETP.

\section{Thrombin potential in platelet poor plasma}

In platelet poor plasma calcium, tissue lactor and phospholipids are administered to trigger coagulation. Since there are no platelets present. phospholipids have to be added. This means that there is a very short lagphase in platelet poor plasma (tig. 1.4), whereas in platelet rich plasma the platelets need time to express their procoagulant phospholipid surface, resulting in a long lag-phase (circa 4 min.). In platelet poor plasma the ETP can also be continuously monitored. ${ }^{150} 1.53$

The protein $\mathrm{C}$ pathway is dependent upon the action of the thrombinthrombomodulin complex. Thrombomodulin normally is linked to the vessel wall, and is not present in the plasma. Therefore, the activated protein $C$ system is not active in isolated plasma. To reveal the role of the protein $C$ pathway it is necessary to add thrombomodulin to the ETP assay. Resistance of factor $V$ to activated protein $C$ (factor $V$ Leiden) and deficiencies of protelns $\mathrm{C}$ and $\mathrm{S}$ are risk factors for venous thrombosis, but they are not very likely to play a role in ischaemic stroke. ${ }^{52426,50}$

\section{The present study}

Effective prevention of stroke is guided by the cause of stroke. In many young stroke patients the stroke cause remains uncerlain. Contliching dala exist about hypercoagulability as a possible contributor lo ischaemic stroke in young patients. Extensive laboratory screening for prethrombotic states in stroke patients is limited to the recognition of a number of known diseases that cause hypercoagulability, such as deficiencies of proteins $\mathrm{C}$ and $\mathrm{S}$, factor $V$ Leiden, hyperhomocysteineemia etc. Such lests are expensive and not widely available. Besides, they often provide only negalive intormation. because they may only exclude one specific known cause of inypercoagulability. Each of these tests is focused on only one protein of the coagulation system, and does not reflect the overall coagulation. Actual overall lests based on clotting lime are not enough sensiltive to hypercoagulability. Therefore, such tests have a low sensitivity, which makes them useless as a screening test for hypercoagulability that may antecede stroke in stroke survivors. Because the laboratory definition of prothrombolic diathesis is evolving rapidy and additional clinical studies continue to identify highmisk subgroups, it would be a great advantage lo have a screening parameter of the coagulation system as a whole, i.e the plasmatic 
coagulation system together with the platelets. In this way further specific testing could be limited to patients with identified hypercoagulability. It was the main aim of this thesis to investigate whether the ETP can be used as such a screening parameler in young stroke patients. With the ETP. measured both in platelet rich plasma and in platelet poor plasma, it is possible to differentiate between hypercoagulability due to platelets, or hypercoagulability due to the plasmatic coagulation system. Also the influence of medication on the hypercoagulability can be sudied with the ETP. Apart from cardioembolic stroke. secondary stroke prevention up till now is limited to antiplatelet therapy, which is only moderately effective. In specilic subgroups other medication, like fxed low-dose oral anticoagulants, may be more effective in preventing vascular events. With the use of the ETP it may be possible to stratify young stroke patients in groups that will benefit from either oral anticoagulant or antiplatelet therapy.

Therelore, in this thesis we set out to explore the role of erythrocyle aggregation (chapler 2), the ETP in platelet poor plasma (chapter 3) and in platelet rich plasma (chapter 4) all in young patients with non-cardioembolic stroke. We also wanted to assess the influence of aspirin and fixed low-dose oral anticoagulants on ETP in healthy subjects and in young stroke patients (chapter 5). 


\section{Chapter}

Enhanced red blood cell aggregation unrelated to fibrinogen:

a possible stroke mechanism in young patients

Based on Faber CG. Troost J, Vermes I. Lodder J, Kalsbeek-Batenburg EM. Kessels F. Haanen $\mathrm{C}$ Enhanced red blood cell aggregation unrelated to fibrinogen a possble stroke mechanism in young stroke patients. Cerebrovasc Dis 1997/770-76 


\section{Abstract}

In many young stroke patients the cause of stroke remains unclear. Enhanced red blood cell aggregation is considered a factor related to the pathogenesis of stroke in elderly patients, in whom enhanced red blood cell aggregation is correlated with increased fibrinogen. We determined red blood cell aggregation, fibrinogen conceniration, hematocrit value and erythrocyle sedimentation rate in 18 stroke patients $\leq 50$ years of age in the early phase and in 40 stroke patients $\leq 50$ years in the late phase, and compared the values to those in young control persons. We also determined these variables in stroke patients $\geq 60$ years of age in the early and in the late phases and in elderly controls. In young stroke patients we found an enhanced red blood cell aggregation compared to young controls ( $p<$ 0.00005 ), both in the early and in the late phases, whereas fibrinogen was normal. Red blood cell aggregation was significantly associated with stroke afler adjusting for fibrinogen, hemalocrit and erythrocyte sedimentation rate (adjusted odds ratio 16.20; 95\% confidence interval (Cl) $2.80-93.61$ ). Red blood cell aggregation was higher in elderly patients than in elderly controls $(p<0.05)$. In elderly patients fibrinogen was associated with stroke (crude odds ratio 12.92; $95 \% \mathrm{Cl} 2.54-65.82$ ), whereas after adjusting for red blood cell aggregation, fibrinogen, hematocrit and erythrocyte sedimentation rate only erythrocyte sedimentation rate showed a significant association with stroke (odds ratio $26.37 ; 95 \% \mathrm{Cl} 1.93$ - 359.74).

In conclusion: Enhanced red blood cell aggregation independently relates to stroke in young people, which may suggest that enhanced red blood cell aggregation contributes to stroke cause, whereas in elderly patients any such effect is probably related to confounding by raised librinogen. 


\section{Introduction}

Despite extensive investigations the cause of stroke remains uncertain in many young patients. ${ }^{28.20} 154$ In 1989, Tanahashi et al. ${ }^{6}$ found enhanced red blood cell aggregation (RBCA) in elderly patients and considered this to be related to the pathogenesis of stroke. They showed a correlation between enhanced RBCA and increased fibrinogen, which in itself is known as a risk factor for stroke. ${ }^{6011415}$ RBCA can also be influenced by the concentration of immunoglobulins. ${ }^{62}{ }^{63}$ Enhanced RBCA increases blood viscosity in states of low shear rate diminishing blood passage through the cerebral capillary circulation. ${ }^{667.7274}$ Therefore, enhanced RBCA may play a role in the cause of ischaemic stroke, specially among the young. We hypothesized that, if RBCA is an independent risk factor for stroke, an increased aggregation would occur more frequently among young patients with stroke compared to elderly patients and controls. We therefore studied RBCA in these three groups of subjects. We also determined fibrinogen concentrations, hematocrit values and erythrocyte sedimentation rates (ESR) as possible confounding factors.

\section{Patients and Methods}

The study population consisted of six groups. Groups I and II represented young stroke patients. Eighteen consecutive patients ( 11 men and 7 women) under age 50 with transient ischaemic attack (TIA) or stroke were included in group I. We investigated the blood of these patients in the early stroke phase (within 2 days after the ischaemic event). Median age was 39 years (range 23-48). Eight patients (44.4\%) had liypertension, 3 palienls (16.3\%) sulfered previous stroke. Group 11 consisted of 40 consecutive stroke patients, 23 men and 17 women, in whom blood was collected in the late phase (at least 2 months after the event, median 29 months, range 2-72 moriths). Fourteen of these patients were investigated also in the early phase. Median age at the time of stroke was 43 years (range 13-50). Of these patients, $2(5 \%)$ had ischaemic heart disease, $20(50 \%)$ had hypertension and $3(7.5 \%)$ diabetes mellitus. Four patients (10\%) suffered previous ischaemic stroke. Groups III and IV represented elderly stroke patients, aged over 60 years. Group III included 20 consecutive patients, 10 men and 10 women, investigated in the early stroke phase. Median age was 73 years (range 62-88). Ten palients $(50 \%)$ had hypertension, 3 patients $(15 \%)$ ischaemic heart disease, 4 patients $(20 \%)$ diabetes mellitus and 4 patients $(20 \%)$ suffered previous stroke. Group IV included 17 stroke patients, 6 men and 11 women, in whom blood was collected in the late phase (median 38 months after the event, range 2 - 108 months). Median age was 79 years (range 62-89). Of these 
patients $4(23.5 \%)$ were known with ischaemic heart disease, $6(35.3 \%)$ had mypertension and $4(23.5 \%)$ diabeles mellitus.

Group $V$ included 34 young control persons, median age 31 years (range $21-49$ ) and group V/ 16 elderly control persons, median age 66 vears (range $60-82)$

Group I and III were prospectively enrolled beween February 1992 and May 1993 at the Medical Spectrum Twente Hospital, Enschede. Group II was registered at the University Hospital Maastricht ${ }^{155}$ and 14 patients of group 1 were also investigated in the late phase. Group IV was retrospectively registered at the Medical Spectrum Twente Hospilal. Control subjects were all reculed at the latter hospital.

Patients with a potential source of cardioembolism and patients with intracerebral haemorhage were excluded from the study. ${ }^{23}$

Investigations in all patients included standard blood tesis, chest radiography, electrocardiography (ECG), non-invasive carotid studies and computer tomography of the brain. We carried out echocardiography, 24 hour ECG monitoring and cerebral angiography in selected patients.

We collected venous blood with minimal occlusion using ethylenediaminetetraacetic acid as anticoagulant and then determined RBCA photometrically in a transparant plate-cone chamber under controlled shear rate (MAI Myrenne Aggregometer, Myrenne GmbH, Roetgen, Germany), 62 156 according to Schmid-Schönbein. ${ }^{15 T}$ RBCA is expressed as extent of shear induced rouleaux formation in percent of normal (SIRF\%). We determined whole blood and plasma viscosity in all young stroke patienls under controlled shear rate (whole blood $14.5 \mathrm{~s}^{-1}$ and serum $230 \mathrm{~s}^{-1}$ ) by a coneplale viscometer (Digital Brookfield Viscometer ype LVT-DVL.CT, Stoughton. Mass. USA) in the early phase (group I) and in the late phase (group II) Because the values for blood and plasma viscosity in young stroke pationts appeared not statistically significantly diferent from those obtained in young control subjects, further measurements were not carried oul in the alder stroke palients. Plasma fibrinogen was determined according to the ClaussVermiflen-thrombin clotting time method (Schnitzer and Gross coagulometer. H. Amelung. Lemgo, Brake. Germany) using bovine thrombin (Topostasin). Hemalocrit and haematologic indices were determined by an automatic cell counter (H1 Technicon Instrument Corp., Terrytown, N.Y. USA). We periomed all tests in duplicate.

Apart from these tests we detemined some other tests in all young stroke patients, like lupus anticoagulant, protein $\mathrm{C}$ and protein $\mathrm{S}$ measurements. In most patients ( 44 of 58 patients) also anticardialipin antibodies were determined. We performed methonine loading lest in 42 of 58 patients. 


\section{Statistical evaluation}

Results are presented as median and range. We used Pearson's correlation coefficient to determine correlation, and the Mann-Whitney test to analyze differences in continuous variables beween groups. We categorized continuous variables using cutoff points at the 33 th and 66 th percentile. Cutoff points were shifted untill each cell had 5 or more participants. If this procedure did not lead to cells with 5 or more participants, variables were dicholomized. We analyzed categorized variables in univariate analysis by means of crude odds ratios (OR) with $95 \%$ confidence intervals (CI). Multivariate logistic regression analysis was subsequently used to determine adjusted odds ratios with $95 \%$ CI with FBCA, fibrinogen, ESF and hematocrit as independent variables, and stroke as dependent variable.

\section{Results}

Median values and range of RBCA, fibrinogen, hematocrit and ESR in the different groups are shown in table 2.1.

\section{Young patients}

RBCA was significantly higher in young stroke patients both in the early and in the late phase, compared to young controls $(p<0.00005$ ). whereas fibrinogen was not (fig. 2.1). ESF was higher compared lo controls $(p=0.0004)$. Hematocrit was normal. Young stroke patients had normal concentrations of immunoglobulins and normal values for medium and high shear viscosity. There was no difference between RBCA in the early or in the late phase. In the 34 patients with a territorial infarcl (30 cortioal, 4 brainstem) mean ABCA was 9.2, in 21 patients with a lacunar infard mean RBCA was 10.9 and in 3 patients with TIA mean RBCA was 8.3 (table 2.2). RBCA was higher in lacunar than in cortical strokes, but not statistically significant (relative risk $2.53,95 \%$ Cl $0.80-7.95$ ).

After adiusting for fibrinogen, hemalocrit and ESP. RBCA was significanily associaled with stroke in young persons (adjusted OR $16.20 ; 95 \% \mathrm{Cl} 2.80$. 93.61. fig. 2.2). There was an association between stroke and the intermediate category of hematocrit values (hemalocrit $0.42-0.46$, adjusted OR $8.70,95 \% \mathrm{Cl} 1.74-43.46$ ). There was no signitican association belween stroke and ESP or fibrimogen concentration. There was no influence of sex. Measurements in haemostasis, like protein $C$ and $S$, revealed no abnormalities. Anticardiolipin antibodies were all negalive. RBCA was mot significantly higher in 7 patients with abnormat methionine loading lest than in 35 patients with normal methionine loading lest. 


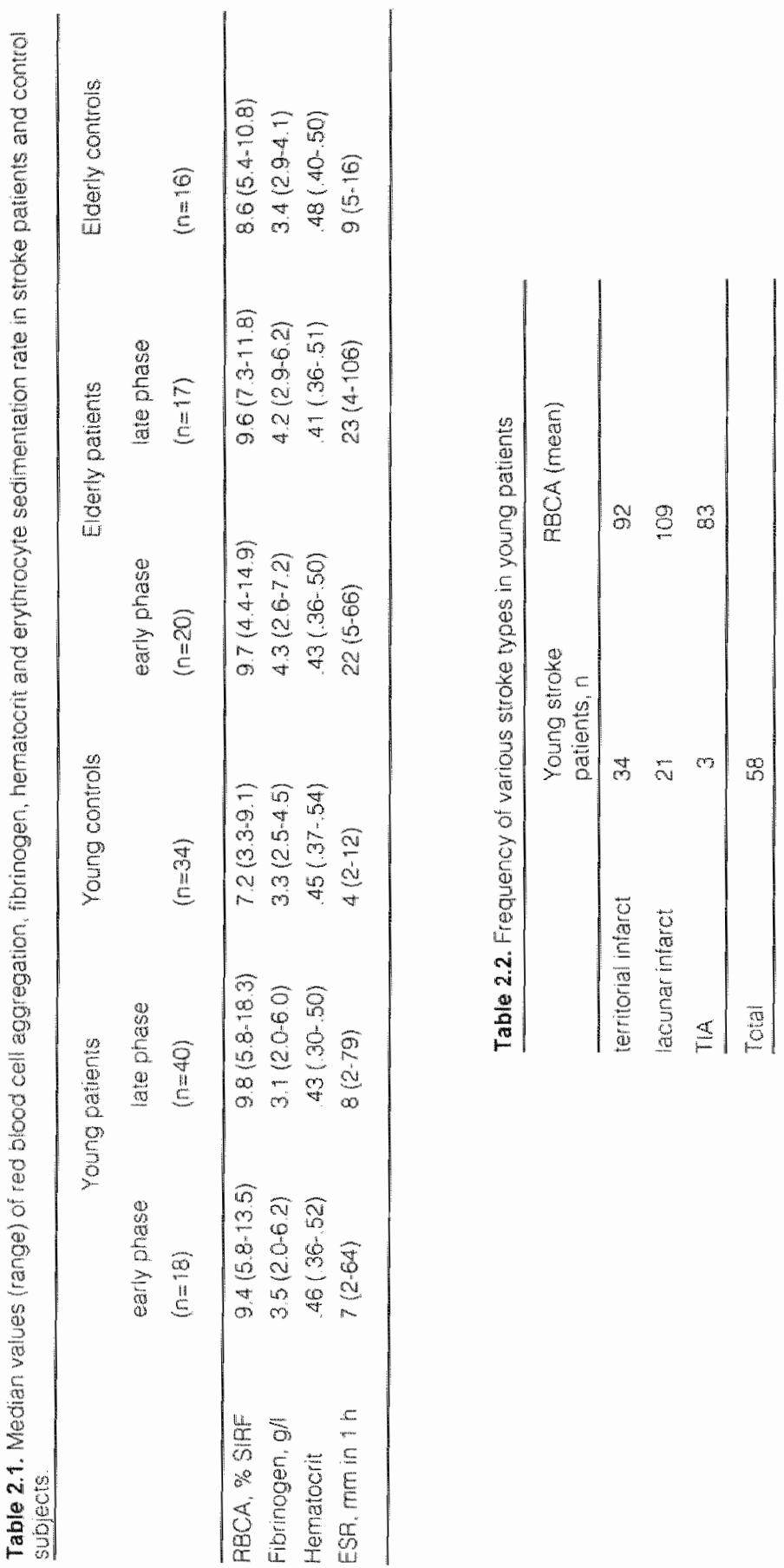




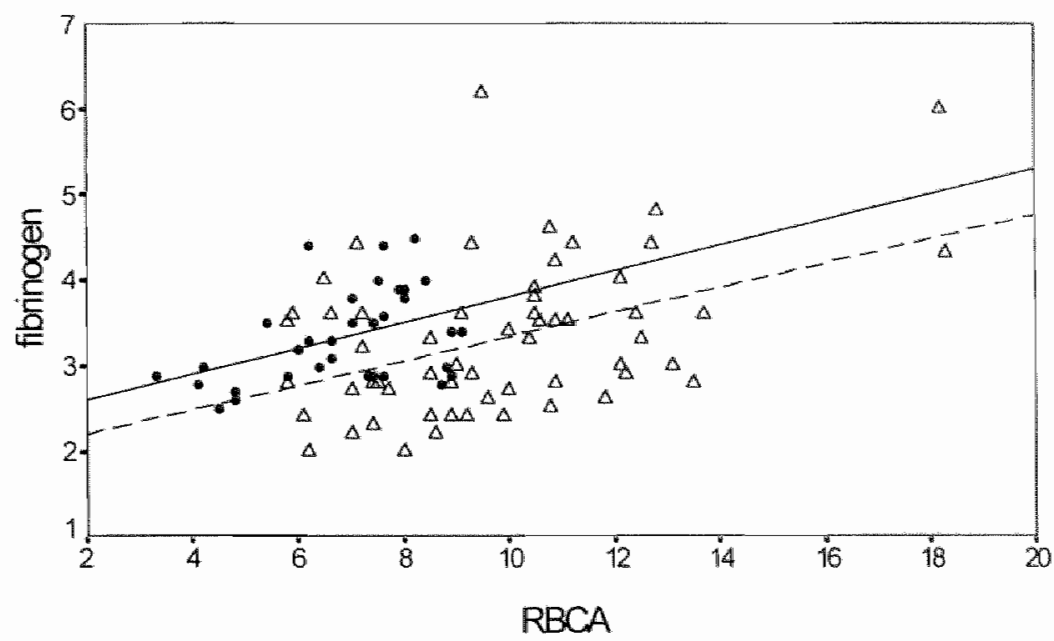

Figure 2.1. RBCA and fibrinogen in young siroke patients (A) compared with young controls ( $\bullet$ ). The regression lines of tibrinogen on RBCA are drawn for patlients (-...) and for controls (-).

RBCA $6.7-8.4$ (Vs. RBCA $\leq 6.6)$

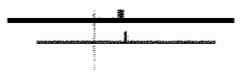

$R B C A=8.5$ (vs. $R B C A \leq 6.6$ )

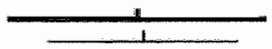

fibrinagen $3.0-3.6$ (ws, fibrinogen $\leq 2.9$ )

fibrinogen 23.7 (ws. fibrinogen 52.9 )

hematocit $0.42-0.46$ ('ws. hematocrt $\leq 0.41$ )

hemetocrit 20.47 (vs. hematocrit $s 0.41$ )

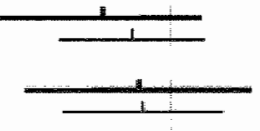

$$
\begin{aligned}
& \text { ESR 4 - 7 (v. ESR - 3) } \\
& \text { ESR } 28 \text { (vs. ESR : 3) }
\end{aligned}
$$

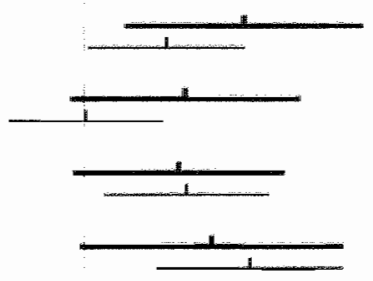

1

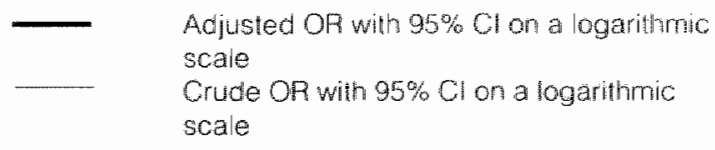

Figure 2.2. Comparison between young stroke pattents and controls by bivariate and multiple logistic regression. An OR>t indicates that the varable is associated with stroke. When the $95 \% \mathrm{Cl}$ crosses the vertical "I "line, the OR is nol significant. 


\section{Elderly patients}

RBCA was higher in eiderly stroke patients compared to elderly controls $(p<0.05)$, as were fibrinogen $(p<0.00005$, fig. 2.3$)$ and ESR $(p<0.00005)$. Hernatocrit values did not differ between groups. After adjusting for RBCA. fibrinogen, hematocrit and ESR only the ESR showed a significant association with ischaemic stroke in these patients (adjusted OR 26.37; 95\% Cl $1.93-359.74$, fig. 2.4). Without adjusting for these variables there was an association between fibrinogen and stroke (crude oR $12.92 ; 95 \% \mathrm{Cl} 2.54$. 65.82), and RBCA and stroke (crude OR 6.33; $95 \% \mathrm{Cl} 1.11-36.0$ ). After adjusting for fibrinogen, the association between RBCA and stroke is no longer significant. There was no association beween hematocrit and stroke. A scatterplot of the values for RBCA in the different groups is presented in figure 2.5 .

\section{Discussion}

Among young stroke patients we found an enhanced RBCA not determined by abnormal concentrations of fibrinogen, immunoglobulins or abnormal hematocrit values. Our groups were too small to allow a logistic model with various acditional variables that could have influenced the results, like stroke subtype, vascular risk factors, or haemostatic parameters. However, various

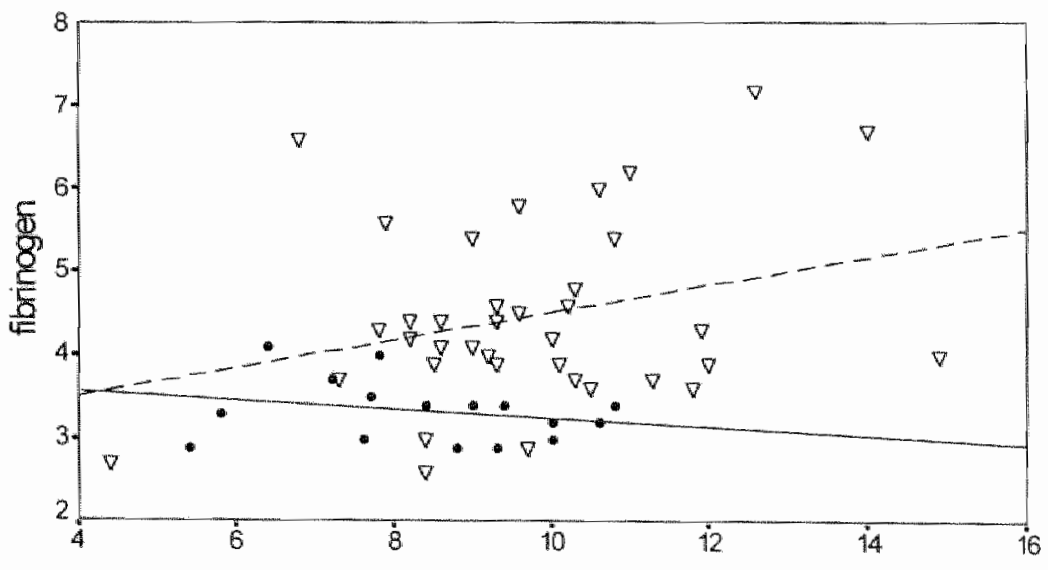

RBCA

Figure 2.3. 17ECA and fibrinogen in elderly stroke patients (W) compared with controls ( ) The regression ines of fiorinogen on BBCA are drawn for elderly patients (-...) and ror controls $(-)$ ). 
RBCA $7.7-9.3$ (VS. RBCA 57.6 )

RBCA 29.4 (vs. RBCA $\div 7.6)$

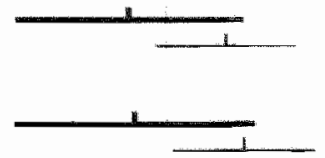

fibrinagen 24,0 (vs. fibrinogen $\leq 3.9$ )

hematocrit $0.42 * 0.46$ (vs hematocilt $\leq 0.41$ )

hematocrit 20.47 (vs, hematocrit $\leq 0.41$ )
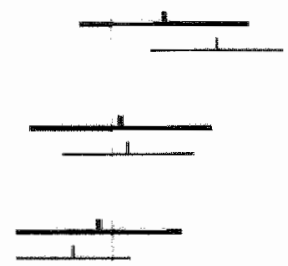

$E S R \geq 12$ (vS $E S R \leq 11)$

0.1

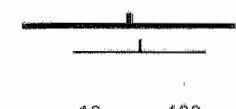

1000

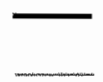

Adusted OP with $95 \% \mathrm{Cl}$ on a togarthmic 50 alo

Crude OP win $95 \%$ Cl on a logarithmo soale

Figure 2.4. Comparison between elderly stroke patients and controls by bivariate and multiple logistic regression. An OA $>1$ indicates that the variable is associated with stroke. When the $95 \%$ Cl crosses the wertical ' 1 ' line, the OP is not signficant

factors influencing haemostasis (protein $\mathrm{C}_{\text {. }}$ protein $\mathrm{S}$, lupus anticoagulant) were normal. Especially during the early phase following stroke. RBCA might have been influenced by various factors. However, it is less likely that stroke would permanently alter RBCA. Our lindings late lollowing stroke may therefore indicate that enhanced RBCA may contribute to the cause of stroke in some young patients. This concurs with the suggestion of Ernst et al.." that enhanced RBCA as a chronic theological disorder may increase the risk of a recurrent ischaemic event.

RBCA measured in vitro may not reflect the situation in wivo. However. haemorheological factors may influence cerebral blood $f l o w^{1 / 3}$ is.th Furthermore, in arteries and veins filled with irregular aggregates of erythrocyles in macroglobulinemic mice, abnormal flow through pial vessels was observed, whereas enhanced RBCA was considered responsible for the observed neurological symptoms in these animals. ${ }^{67}$ However, although our findings suggest that enhanced RBCA may act as a cause of stroke, our study design does not permit definitely such a conclusion. 


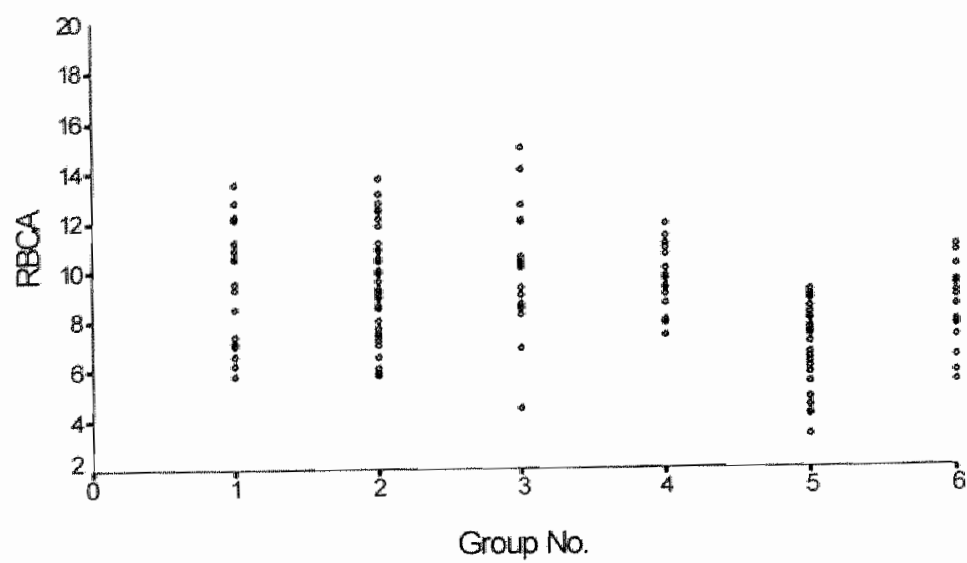

Figure 2.5. Scatterplot of the values for RBCA in the difterent groups. Group $1=$ young stroke patients in the early stroke phase; group $2=$ young patients in the late stroke phase; group $3=$ elderlly stroke patients in the acuie stroke phase: group $4=$ alderly stroke patients in the chronic phase; group $5=$ young controls; group $6=$ eluerly controls.

The physiological importance of RBCA is its tendency to increase the blood viscosity in low shear flow and to disturb the passage in cappillary circulation through the formation of sludge. ${ }^{159}$ Especially after a poststenotic pressure drop shear stresses are diminished and RBCA might be enhanced. Small arteriolar stenoses are oftem found in lacunar disease. We found enhanced aggregation more frequently among young patients with lacunar than with cortical stroke, but, probably due to small numbers, this difference was not statistically significant. Others also mentioned enhanced RBCA in palients with lacunar stroke. ${ }^{\text {?4 }}$ Whether enhanced RBCA occurs more frequently in patients with small vessel disease than in those with large vessel disease remains to be investigated.

Most of our young stroke patients had a normal hematocrit and therefore were classified in the intermediate category of hematocrit value, which explains the association between stroke and the intermediate category of hematocrit value in these patients.

Elderly patients had a slighly higher BBCA than controls, but mutivariate regression analysis showed no independent correlation between enhanced RBCA and stroke in this group, due to a strong association with fibrinogen concentration. Fibrinogen is knowm as a risk factor for vascular disease, ${ }^{14415}$ and is associaled with an enhanced PBCA. ${ }^{6}$

Fibrinogen and ESR are strongly correlated; ESR will be high if fibrinogen is raised. Crude OR for librinogen in our series was high, but after 
multivariale logistic regression analysis with $\mathrm{ABCA}$. ESR, fibrinogen and hematocrit as independent variables only the adjusted OR lor ESR remained significant.

We investigated young stroke patients registered prospectively in the past, " ${ }^{2}$ who were able and willing to come to the hospital, and therefore included functionally less affected patients. In case of a relationship between the enhanced RBCA and degree of neurological deficit, any relationship would have been towards an underestimation of the strength of association between the rheological disorder and stroke. We consider a selection bias towards the opposite direction less likely.

For our statistical analysis of continuous variables we chose cutolf points at the 33th and 66th percentile. Changing cutoff points did not essentially change the outcome. Furthermore, shifting cutoff points unlil each cell had 5 or more participants was done to prevent emply cells in the multivariate regression analysis and thereby extremely high odds ratios.

A cause for the enhanced RBCA in young stroke patients was not found. May be some plasma protein, other than fibrinogen, could be responsible lor the enhanced RBCA. This would be of future interest.

In conclusion: In young patients RBCA may independently contribute to stroke cause, whereas in elderly patients any such effect is probably related to confounding by raised fibrinogen. 


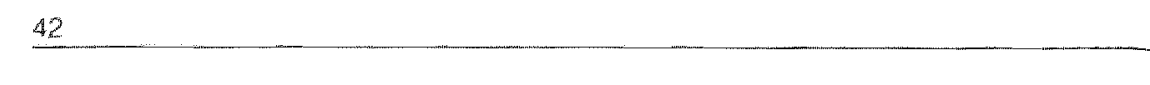


Chapter

Thrombin generation in platelet poor plasma of young stroke patients 


\section{Abstract}

Haemostatic abnormalities may coniribute to the development of stroke in young patients. We used the thrombin potential, an overall indicator of the plasma coagulability, to determine whether young stroke patients have abnormalities in the plasmatic coagulation system. To investigate whether there were any disturbances in the protein $\mathrm{C}$ pathway, we also added thrombomodulin to the thrombin generation assay. We determined the extrinsic and the intrinsic thrombin potential in 41 young stroke patients ( $\leqslant 50$ years) and in 70 healthy control persons. Based on the 33th and 66ith percentile of the extrinsic thrombin potential values, patients were divided into three categories. We found a plasma based hypercoagulability in about one third of young stroke patients. Patients with recurrent stroke had a significantly higher thrombin potential than other patients $(p=0.03)$. After the addition of thrombomodulin five patients had an insufficient inhibition of thrombin generation, indicating an abnormality of the protein $C$ pathway.

In conclusion: With the use of the thrombin potential in platelet poor plasma as a screening parameter of the plasmatic coagulation system, we identified hypercoagulability in approximately one third of young stroke patients. Patients with recurrent stroke have a higher thrombin potential than those without. Abnormalities in the protein $\mathrm{C}$ pathway are easily detectable with the thrombomodulin test, and may contribute to the development of stroke in the presence of other vascular risk factors. In patients with an identified hyperactive coagulation system, further investigations into the cause of this plasma based thrombotic tendency are warranted. 


\section{Introduction}

Thrombin represents the end product of numerous enzymatic reactions in the clotting system. The production of thrombin is controlled by inhibitory reactions due to plasma antiproteases (e.g. antithrombin and $\alpha_{2}$ macroglobulin) and negative feedback reactions, initiated by thrombin itself, as in the protein $C$ pathway. When too much free thrombin is generated, a thrombotic tendency occurs (hypercoagulability). There are many laboratory tests that may point at an underlying specific cause of such hypercoagulability, among which are the determination of the various clotting factors. A single laboratory parameter that is increased in all forms of hypercoagulability would be very useful for the detection of plasma based thrombotic tendency. The time integral of thrombin formation, i.e. the endogenous thrombin potential (ETP), is an overall indicator of the plasma coagulability, and might therefore be a good candidate lor detecting abnormalities in the coagulation system. The thrombin potential is known to be elevated in patients with antithrombin deficiency (about 40\%), deep venous thrombosis (about 29\%), in patients with ischaemic heart disease (about $10 \%)^{160}$ and in women using oral contraceptives (about 17\%). ${ }^{161162}$

Until now, in many young stroke patients the underlying cause of stroke remains unclear. In up to a quarter of young stroke patients a haematologic abnormality may contribute to the development of stroke. ${ }^{54} 2^{55}$ Antithrombin deficiency, protein $S$ deficiency, protein $\mathrm{C}$ deficiency, antiphospholipid antibodies, and activated protein $C$ resistance are said to be related to stroke at young age, but their quantitative contribution to the development of stroke is at least doubtful. ${ }^{54} 26-30$ in some of these disorders the ETP is increased. 160

Disorders in the protein $C$ pathway increase thrombin lormation by intertering with the mechanism that down-regulates the action of prothrombinase. This pathway is initialed by the interaction of thrombin with thrombomoduin (TM). The thrombin-TM complex activates protein $C$. Activated protein C (APC), together with protein S, inaclivates lactors Va and VIlla and consequently shuts down further thrombin generation. This mechanism is impaired in congenilal deticiency of proteins $\mathrm{C}$ and $\mathrm{S}$ or, more frequently, by resistance of factor $V$ to the action of protein $C$. The latter disorder can be either congenital, ${ }^{163.165}$ or acquired, e.g. by the intake of oral contraceptives. ${ }^{16 z}$ Disorders of the protein $\mathrm{C}$ pathway cause a slight, but significant elevation of the ETP (of aboull 10\%) ${ }^{16 \%} 162$ In the presence of added TM (or APC) in healthy controls a decrease of the ETP is observed. In the case of APC resistance of factor $V$, the decrease of the ETP is significantly less pronounced after addition of TM or APC.

Thrombomodulin is nomally linked to the wessel wall. Therefore, it is impossible to define the 'physiological concentrations' in a soluble reaction 
mixture as we use for the ETP. The ETP without TM and with an optinal concentration of solubilized TM obviously represent the two extremes of the physiological situations. We therefore tested the ETP in the extrinsic system with and without added soluble TM. ${ }^{167}$ To reveal disorders in the mechanism that is dependent upon the factors VIII. IX or XI we also determined the ETP in the intrinsic system. Under physiological circumstances these factors come into play at low tissue factor concentrations, but in vitro their activity is best revealed in a contact-activated system (i.e. intrinsic pathway).

\section{Patients, materials and methods}

\section{Patients}

There were 41 consecutive patients under age 50 with ischaemic stroke (three patients had a TIA), between July 1986 and July 1996, and 70 healthy volunteers. Age and sex were similar in both groups. After approval of the medical ethical committee, written informed consent was obtained, both from patients and controls. Routine investigations in the patient group included standard blood tests, electrocardiogram, brain CT, non-invasive carotid studies and echocardiography. Cerebral angiography was performed in 21 cases for specific individual reasons. Clinical characteristics of patients and controls are listed in table 3.1 and 3.2. All patients were investigated at least 3 months after the ischaemic event, to exclude the influence of acute phase reactions on the measurements.

Patients with a specific stroke cause, such as a potential source of cardioembolism or an arterial dissection, and patients with intracranial haemorhage were excluded from the study.

\section{Materials}

\section{Plasma}

Blood was collected on $0.13 \mathrm{M}$ trisodium citrate; nine parts of blood to one part ol citrate solution. An open (non-vacuum) venipuncture was pertormed in order to avoid platelet activation. The first $\mathrm{ml}$ of blood was discarded to get rid of venipuncture related tissue factor. Samples were centrifuged twice at $1000 \times \mathrm{g}$, at $15^{\circ} \mathrm{C}$ for $10 \mathrm{~min}$. This plasma was stored at $-80^{\circ} \mathrm{C}$

Normal pool plasma was obtained in the same way from at least 10 healthy donors, and pooled. The pool was centrifuged uwice at $1000 \times \mathrm{g}$, at $15^{\circ} \mathrm{C}$ for $10 \mathrm{~min}$ and stored in $1 \mathrm{mll}$ aliquots at $-80^{\circ} \mathrm{C}$ 
Table 3.1. Clinical characheristics of young stroke patients and controls

\begin{tabular}{|c|c|c|}
\hline & $\begin{array}{l}\text { patients } \\
n=41\end{array}$ & $\begin{array}{l}\text { controls } \\
n=70\end{array}$ \\
\hline $\begin{array}{l}\text { age (mean } \pm \text { SD) } \\
\text { range }\end{array}$ & $\begin{array}{l}43.9( \pm 6.0) \\
25.50\end{array}$ & $\begin{array}{l}395( \pm 8.9) \\
23-57\end{array}$ \\
\hline sex & 19 male $(46.3 \%)$ & 33 male $\{47.1 \%\}$ \\
\hline \multicolumn{3}{|l|}{ Medical history } \\
\hline Prior stroke/TIA & $4(9.8 \%)$ & 0 \\
\hline Myocardiall inarcion & $3(73 \%)$ & 0 \\
\hline Angina pectoris & $5(122 \%)$ & 0 \\
\hline Peripheral artery disease & $4(9.8 \%)$ & 0 \\
\hline Hypertension & $19(46.3 \%)$ & $3(43 \%)$ \\
\hline Hypertensive medication & $12(293 \%)$ & 0 \\
\hline Chronic obstructive pulmonary disease & $3(7.3 \%)$ & $3(4.3 \%)$ \\
\hline Diabetes mellitus & $2(4.9 \%)$ & 0 \\
\hline Hypercholesterolaemia & $12(29.3 \%)$ & $1(1.4 \%)$ \\
\hline Vascular tamily history & $24(58.5 \%)$ & $33(47,1 \%)$ \\
\hline Oral contraceptive use & $9(22.0 \%)$ & $10(143 \%)$ \\
\hline Snoking & $28(68.3 \%)$ & $20(28.6 \%)$ \\
\hline Use of alcohol & $16(39.0 \%)$ & $58(829 \%)$ \\
\hline Alcohol units/week (among users) & $12.4( \pm 10.7)$ & $8.1( \pm 9.3)$ \\
\hline \multicolumn{3}{|l|}{ Stroke type } \\
\hline Cortical & $23(56.1 \%)$ & \\
\hline Lacumar & $9(220 \%)$ & \\
\hline Cerebellar & 百 $(24 \%)$ & \\
\hline Branstem & $5(122 \%)$ & \\
\hline THA & $3(73 \%)$ & \\
\hline
\end{tabular}

\section{Reagents}

- Ancrod, a fibrinogen clotting enzyme of the Malayan Pit Viper, was oblained as the commercial preparation Arwin (Knoll AG, Ludwigshaten, Germany).

- Butter A consisted of $20 \mathrm{mM}$ Hepes-NaOH, $150 \mathrm{mM} \mathrm{NaCl}, 0.5 \mathrm{~g} / \mathrm{l}$ Bovine Serum Albumin (BSA; Lol: A-7030, Sigma), pH 7.35.

- Relipidated recombinant lissue factor preparations, in which phospholipids are present, were a gifl of Dade Productions (Düdingen. Switzerland). 
Tabie 3.2. Data on routue laboratory investigations in 41 young stroke patients

\begin{tabular}{|c|c|c|}
\hline & & nomal values \\
\hline Hemoglobin (mmolly) & $8.93( \pm 0.98)$ & $82-11.0$ \\
\hline Hematocrit (1/) & $0.42( \pm 0.05)$ & $0.40-0.52$ \\
\hline Leucocytes $\left(x 10^{\circ} n\right)$ & $791( \pm 2.18)$ & $3.5 \cdot 11.0$ \\
\hline Thrombocytes $\left(x 10^{\mathrm{\theta}} / 1\right)$ & $2903( \pm 88.7)$ & $430-350$ \\
\hline Cholesterol (mmolli) & $60 \quad( \pm 12)$ & 4.164 \\
\hline Triglycerides (nmol/l) & $193( \pm 0.92)$ & $0.80-1.94$ \\
\hline Number of patients with: & & prevalence in the normal population \\
\hline Anticardiolipin antibodies & $2(4.9 \%)$ & $7.8 \% 39$ \\
\hline Lupus anticoagulant & $1(2.4 \%)$ & $1-2 \%$ \\
\hline Hyperhomocysteinaemia & $6(14.6 \%)$ & $5.7 \%$ \\
\hline
\end{tabular}

- Phospholipids (Avanti Polar Lipids, Alabama, USA) consisted of phosphatidyl serine (PS), phasphatidyl choline (PC) and phosphatidyl ethanolamine (PE) in proportions of 20,60 and $20 \%$, respectively. These phospholipids were used in a solution of $5.28 \mathrm{\mu M}$. In the thrombomaduin test the final concentration was $1.1 \mathrm{fM}$

- SQ68 (Diagnostica Stago, Boehringer, Mannheim) was used as substrate for thrombin in the intrinsic pathway.

- For the extrinsic pathway and the thrombomadulin test we used MSC Val Arg PNA (MSCV), a novel chromogenic substrate synthesized in our laboratory and described in detail elsewhere. ${ }^{160} 168$ For the details of the determination of the ETP with different substrates, see Hernker (1993) or Wielders (1997) ${ }^{150}$ Here it suffices to say that the optical density signal with MSCV is 1.97 than that obtained with SQ68.

- As a trigger for the extrinsic pathway we used recombinant tissue factor in a concentration of about $30 \mathrm{pM}$. For the intrinsic pathway we used Actin FS (Dade Productions, Düdingen, Switzerland), a suspension of ellagic acid and soy bean phosphatides. Actin FS was diluted 1:2.5.

- Thrombomodulin (Kordia, Leiden, The Netherlands) was used in a fina concentration of $30 \mathrm{mM}$.

\section{Methods}

\section{Defibrination of plasma}

To allow measurements of optical density, plasma had to be defibrinated. Defibrination was achieved by coagulation of $1 \mathrm{ml}$ plasma with 14 Ancrod. The samples were incubated for $10 \mathrm{~min}$ at $37^{\circ} \mathrm{C}$, allowing the formed fibrin to 
polymerize, then kept on ice for $10 \mathrm{~min}$. The resulting clot was removed from the plasma by winding it out on a small plastic spatula. It has been determined that this procedure does not activate the clotting system. ${ }^{150}$

\section{Measurement of thrombin generation in PPP}

Thrombin generation in PPP was measured using continuous monitoring of thrombin formation, as described earlier. ${ }^{150}$ This method, in which a slow reacting thrombin substrate was used, has been adapted for high throughput screening on a Cobas centrifugal analyzer. ${ }^{160}$ This automaton can measure 28 samples simultaneously. The volumes used were $80 \mu$ th of defibrinated plasma and 20 fl of recombinant tissue factor solution (for the extrinsic pathway) or $20 \mu$ of Actin FS solution (for the intrinsic pathway). After 30 sec of incubation. which is sufficient for temperature equilibration. thrombin generation was started by adding $20 \mu$ of a prewarmed start solution containing $0,1 \mathrm{M} \mathrm{CaCl}$ and $3 \mathrm{mM}$ of substrate. Aftel the start of the reaction the optical density at $405 \mathrm{~nm}$ was recorded at intervals of maximally 30 sec for at least 15 min. For data handling the centrifugal analyzer was connected to a personal computer.

\section{Calculation of the thrombin potential}

The thrombin potential can not be abtained directly from the optical density that develops during the experiment, because thirombin is not the only enzyme to convert the substrate. Part of the free thrombin is irreversibly bound to $\alpha_{2}$-macroglobulin to form a complex that retains amidolytic activity. The course of optical density in time that is experimentally obtained has to be split in the part due to the activity of free thrombin and the part due to the $\alpha_{2}$ macroglobulin-thrombin complex by a mathematical procedure. ${ }^{160}$ The thrombin potential is expressed as a percentage of the ETP in normal pool plasma.

\section{Thrombomodulin test}

This test is based on the extrinsic thrombin generation lest in which the amount of tissue factor is reduced firom 15 to $0.15 \mathrm{ng}$. Thrombin bound 10 thrombomodulin activales protein $\mathrm{C}$. Then this serine protease will inactivate the factors $\mathrm{Va}$ and VIlla and consequently will reduce the thrombin formation. thus the ETP will decrease. In this way it is possible to investigate the function of the protein $C$ pathway. To $75 \mu$ defibrinated plasma was added $25 \mathrm{\mu l}$ of a solution containing: $5.28 \mu \mathrm{M}$ phospholipids (PS, PC and PE, see the materials section), recombinant tissue factor (about $7.2 \mathrm{pg}$ ) and $720 \mathrm{WM}$ thrombomodulin. After 30 sec of incubation at $37^{\circ} \mathrm{C}$ in the Cobas machime thrombin generation was started by adding 20 ul of a prewarmed solution containing $0,1 \mathrm{M} \mathrm{CaCl}_{2}$ and $3 \mathrm{mM}$ of chromogenic substrate (MSCV). The final concentration of phospholipids was $1.1 \mu \mathrm{M}$, of thrombomodulin $30 \mathrm{nM}$ 
and of recombinant issue factor $0.15 \mathrm{ng}$. With this concentration of issue factor the clotting lime in glass was 60 sec. The thrombomodulin concentration was choosen to obtain an inhibition of around $40 \%$ of the ETP of the normal pool plasma. The result of the thrombomaduln test is expressed as a percentage of the intibition obtamed by the addition of thrombomodulin to normal pool plasma, and was detemined in 37 patients and in 24 controls.

\section{Statistical evaluation}

Results are presented as median and the 25 and 75 percentiles. We used the Kendall's tau to determine correlation, and the Mann-Whitney test to analyze differences in continuous variables between groups. Patients were categorized in groups using cutoff points at the 33 th and 66 th percentile of the value of the ETP. In the thrombomodulin test we considered a percentage inhibition below the 5 th percentile of the control group (this was a percentage inhibition of less than $57 \%$ of the ETP after addition of thrombomodulin) as an insufficient reaction to thrombomodulin. We analyzed the association between stroke and the thrombomodulin test by means of odds ratios (OR) with $95 \%$ confidence intervals (Cl) with a logistic regression model.

\section{Results}

Median values (25-75 precentite) of the ETP in the extrinsic and intrinsic pathway and of the thrombomodulin test are shown in table 3.3. The Mann. Whitney test did not show a significant difference between ETP values in young stroke patients and controls.

Table 3.3. Median walues (25.75 percenile) of ETP in the extrinsic and intrinsic pathway, and of the kthombomoduling iest (TM) in young stroke patients and ir controis

\begin{tabular}{lll} 
& $\begin{array}{l}\text { Young stroke patients } \\
n=41\end{array}$ & $\begin{array}{l}\text { Controls } \\
n=70\end{array}$ \\
\hline ETP extrinsic & $106(93-121)$ & $105(98-113)$ \\
ETP intrinsic & $105(87-122)$ & $100(91-110)$ \\
TM & $81(62-97)^{*}$ & $79(68-88)^{\prime \prime}$ \\
\hline
\end{tabular}

\footnotetext{
delemaned in 3 patients and in 24 controls (see the methods section)
} 
The patients were categorized, using cutoff points at the 33 th and 66 th percentile of the values of the ETP (table 3.4). Numbers of patients and controls (in percentages) in these three categories are shown in fig. 3.1 . There was a significant correlation between ETP in the extrinsic and in the intrinsic pathway (Kendall's tau 0.57, p<0.001) (fig.3.2). Pationts with peripheral artery disease $(n=4)$ had higher ETP compared with other patients (extrinsic $123(111-136)$, intrinsic $133(116-168), p=0.03$ and $p=0.02$, respectively). Patients who suffered a recurrent stroke $(n=8)$ also had a significantly higher ETP in the extrinsic pathway $(p=0.03$ ) (table 3.5). Using the Mann-Whitney test no significant differences were found between patients with or without ischaemic heart disease, hypertension, hyperhomocysteinaemia, diabetes or current smoking. A significant difference was found in ETP in the extrinsic and in the intrinsic pathway between males and females. Females had a lower ETP, both in the control and in the patient group $(\mathrm{p}<0.01)$.

There were 5 patients with an insufficient inhibition of the ETP after addition of thrombomodulin. These patients showed an inhibition of 13,32 , 45,48 and $56 \%$, respectively. The values of the thrombomodulin test for patients and controls are shown in figure 3.3 . In a logistic regression model an insufficient inhibition in the thrombomodulin lest was significantly associated with stroke (odds ratio $9.9 ; 95 \% \mathrm{Cl} 1.1-87.6)$. Patients with an insufficient inhibition in the thrombomodulin test were all temales. Four of these patients had a normal ETP. Three of these patients used oral contraceptives at the time of the ischaemic event (all patients stopped oral contraceptive use after their stroke), and four smoked cigarettes. Two patients had a hyperhomocysteinaemia.

Table 3.4. Pesults in median (25-75 percentile) of ETP in the extrinsic and in the intrinsic pathway, and of the thrombomodulin test (TM) in three categories based on the extrinsic ETP values in patients and in controls.

\begin{tabular}{|c|c|c|c|c|c|c|}
\hline & \multicolumn{2}{|c|}{$\begin{array}{l}\text { Group } 1 \\
\text { (ETP } \leq 96)\end{array}$} & \multicolumn{2}{|c|}{$\begin{array}{c}\text { Group } 2 \\
\text { (ETP } 97-117)\end{array}$} & \multicolumn{2}{|c|}{$\begin{array}{c}\text { Group } 3 \\
(E T P \geq 118)\end{array}$} \\
\hline & $\begin{array}{l}\text { Controls } \\
n=15\end{array}$ & $\begin{array}{l}\text { Patients } \\
n=14\end{array}$ & $\begin{array}{l}\text { Controls } \\
n=45\end{array}$ & $\begin{array}{l}\text { Patients: } \\
n=13\end{array}$ & $\begin{array}{l}\text { Comtrols } \\
n=10\end{array}$ & $\begin{array}{l}\text { Pailents } \\
n=14\end{array}$ \\
\hline $\begin{array}{l}\text { ETP } \\
\text { exirinsic }\end{array}$ & $87(78-92)$ & $89(86-93)$ & $105(101-113)$ & $106(101-114)$ & $121(19-122)$ & $122(121-127)$ \\
\hline $\begin{array}{l}\text { ETP } \\
\text { intrinsio }\end{array}$ & $78(70-90)$ & $83(74-94)$ & $102(93-111)$ & $105(96-108)$ & $111(96-115)$ & $128(121-145)$ \\
\hline$T M$ & $61(53-83)$ & $80(67-87)$ & $78(71.82)$ & $75(58-96)$ & $93(83100)$ & $93(65.111)$ \\
\hline
\end{tabular}




\section{Contrals Patients}

70

60

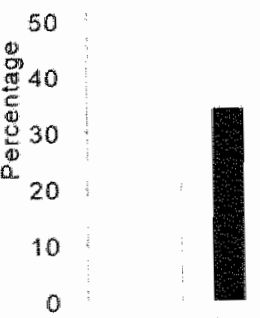

$\leq 96$

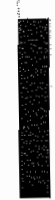

$97 \cdot 1117$

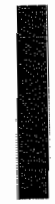

¿118

Extringio ETP

Figure 3.1. Percontages of extringic ETP values in the three categories (based on $33 \mathrm{~h}$ and 66 th percentile) in patients and controls. Patients are more present both in the lower and in the higher range, whereas the controls are mostly in the middie range of the ETP values.

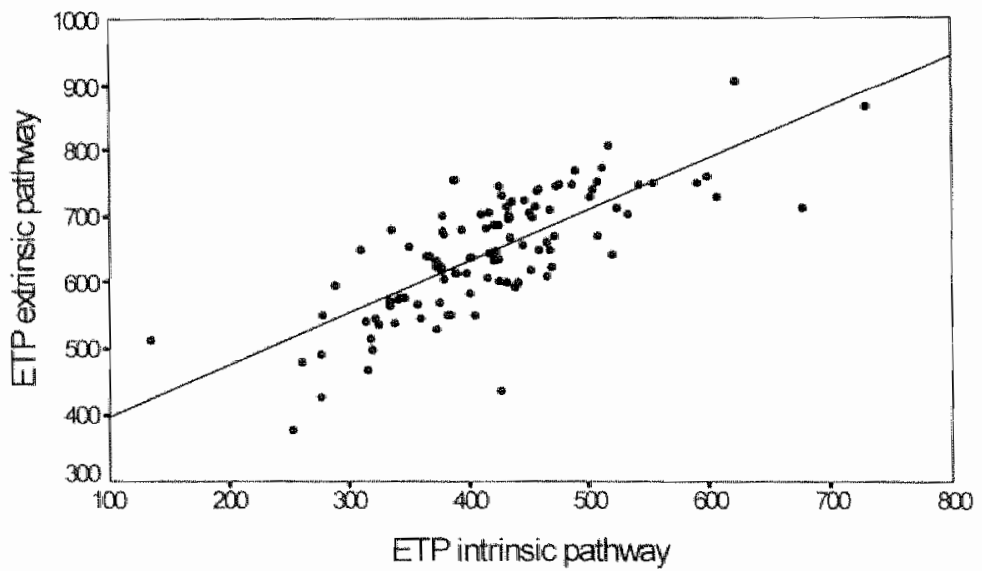

Figure 3.2. Comelation of the ETP it the extrinsic and in the intrinsic pathway in young stroke patients and in controls. The regression line of extrinsic on intrinsic ETP is drawn. There is a highy significant correlation between the extrinsic and the Inthinsic ETP. 
Table 3.5. Median values (25-75 percentile) of ETP in extrinsic and irtrinsic pathway and of the thrombomodulin tes? (TM) young siroke patients whihout and with recurrent stroke (AS).

\begin{tabular}{|c|c|c|c|c|c|}
\hline \multirow[b]{2}{*}{ ETP extrinsic } & \multicolumn{2}{|c|}{$\begin{array}{l}\text { Patients without } A 5 \\
n=33\end{array}$} & \multicolumn{2}{|c|}{$\begin{array}{l}\text { Patienis with } \mathrm{PS} \\
\mathrm{n}=\mathrm{g}\end{array}$} & \multirow{2}{*}{$\frac{p \text {-ualue }}{3}$} \\
\hline & 102 & $(90 m 121)$ & 119 & $(110-136)$ & \\
\hline ETP intrinsic & 102 & $(83-120\}$ & 116 & $(101-143)$ & NS $(0,0502)$ \\
\hline TM & 81 & $(62-97)$ & 78 & $(60-100)$ & NS \\
\hline
\end{tabular}

\section{Discussion}

With the use of the ETP in PPP as a screening parameter of the plasmatic coagulation system, we identified hypercoagulability in approximately one third of young stroke patients. A striking finding was that patients with recurrent stroke had significantly higher ETP than those without. This could indicate that patients with a plasma based hypercoagulability have a higher risk of developing recurrent stroke. Stroke probably is multicausal in origin and it may be more appropriale to think of hypercoagulability as one of the possible contributing causes, or in other words, as a risk facior. Coagulopathy as contributor to the development of stroke in the young may vary from $1-25 \%$, but a definite relationship with stroke remains unclear. ${ }^{5} 2425$ 169170 The question to what extent an existing hypercoagulability is a risk factor for the development of stroke is difficult to answer as long as the definition and detection of hypercoagulability are limited to a relatively small number of known diseases that cause hypercoagulability, such as deficiencies of proteins $\mathrm{C}$ and $\mathrm{S}$, factor $\mathrm{V}$ Leiden, anticardiolipin antibodies and hyper-homocysteinaemia. Most of these disorders are unlikely 10 play a quantitative role in the development of stroke. ${ }^{5426-30: 39}$ As yet unidentified hypercoagulable states undoubtedly account for many other prethrombotic states. ${ }^{17}$ The ETP offers the possibility 10 detect abnormalities in the haemostatic function of the blood, and appears to be rather sensilive. ETP does not allow identification of a specific underlying coagulation disorder, as it is an overall test of the coagulation system. Therefore, what caused the plasma based hypercoagulable state in our young stroke patients is not yel clear. Abnormalities in the protein $C$ pathway can not be held responsible for the observed hypercoagulability in our patients, because their thrombo. modulin inhibition was normall. ETP increases with the use of orat contraceptives, whereas sensitivity to activated protein $\mathrm{C}$ decreases. ${ }^{152}$ Because all patients stopped taking the contraceptive pill after their stroke, oral contraceptive use is not likely to be the cause of our tindings. 


\section{Controls Patients}

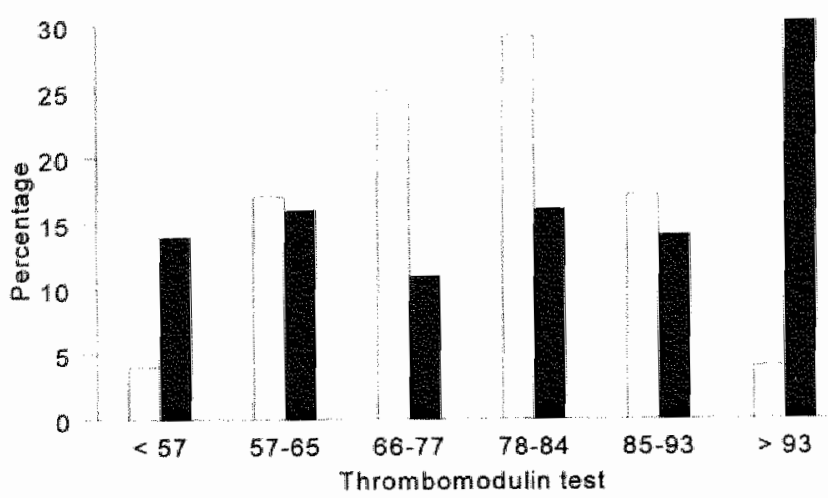

Figure 3.3. Percentages of controls and patients in subgroups. according to the walue of the thrombomodulin test (in percentage inhibition). From this figure it is clear that the values of the thrombomodulin test in the controls show a normal distribution pattern. whereas the patierts have more values both in the higher and in the lower range.

With the standard thrombin generation test to which thrombomodulin is added, the function of the protein $\mathrm{C}$ pathway can be explored. From previous experiments we know that percentages of inhibition in the thrombornodulin test in patients with protein $C$ deficiency, protein $S$ deficiency, or factor $V$ Leiden are low $(40 \pm 9 \%, 23 \pm 9 \%, 56 \pm 18 \%$, respectively, versus $81 \pm 16 \%$ in controls) (Wielders, personal communication 1998). An insufficient decrease of the ETP after addition of thrombomodulin allows detection of an abnormality in the protein $\mathrm{C}$ pathway. This pathway plays an important role in the inactivation of thrombin. Consequently, an abnormality in the protein $C$ pathway could induce a prethrombotic state ${ }^{30} 172$ 173 Therefore, our five patients with an insufficient response to thrombomodulin probably had a prethrombotic state. Abnormalities in the protein $\mathrm{C}$ pathway are especlally associated with venous thrombosis, but the precise role of protein $C$ or protein $S$ deticiency or of lactor $V$ Leiden as contributtors to stroke is uncertain. ${ }^{24} 261721 \% 4$ Deficiency of protein $C$ or protein $S$, or resistance to activated protein $\mathrm{C}$ (factor $\mathrm{V}$ Leiden) have been linked with stroke in many case reports. ${ }^{173}$ 1\%5.8 Currently it is belleved that these disorders are not the primary cause of stroke, but rather enhance an already existing increased stroke risk. ${ }^{24} 27293053192$ t89 Thus, a thrombotic event may result from the convergence of an (inherited) predisposition to thrombosis (like protein $C$ deficiency or factor $V$ Leiden) with an acquired thrombogenic stimulus (e.g. atherogenic risk factors). ${ }^{31} 1711^{184}$ All our five patients with an abnormal 
thrombomodulin test had one or more additional vascular risk lactors at the lime of the stroke (smoking $(n=4)$, oral contraceptive use $(n=3)$, hyperhomacysteinaemia $(n=2)$ ). This concurs with the findings that factor $V$ Leiden increased the risk of myocardial infarction in women. whereas this increased risk was largely confined to current smokers. ${ }^{32}$

Our study could be criticized for the reason that we performed our measurements following and not prior to stroke: a haematologic abnomality identified after stroke did not necessarily antedate the stroke, and can be a consequence rather than the cause of stroke. However, support for an antecedent, causal role of the haematologic disorder includes its persistence in subsequent months. For this reason we tested our patients a least 3 months after the ischaemic event. Therefore, we believe that our findings are not merely a consequence of stroke, but that many patients under 50 with cryptogenic stroke have hypercoagulability that may play an important role in the development of stroke. This idea is supported by the finding that high ETP is associated with recurrent stroke. Further study may also identify a role of ETP detected hypercoagulability in elderly patients, in whom atherosclerosis is the most likely stroke cause.

In conclusion: In a subgroup of young stroke patients hypercoagulability can be identified via the thrombin generation test. Patients with recurrent stroke had a higher ETP than those without. Abnormalities in the protein $C$ pathway, as detected by the thrombomodulin, test are more common in young stroke patients than in controls. These protein $C$ pathway abnormalities may contribute to the development of stroke, especially in the presence of other vascular risk lactors. In patients with an identilied hyperactive coagulation system, further investigations into the cause of this plasma based thrombotic tendency are warranted. 
56 
Chapter

Thrombin generation in platelet rich plasma, platelet derived procoagulant activity, and von Willebrand factor in young stroke patients 


\section{Abstract}

How often coagulation disturbances are the cause of stroke in young people remains unclear, as reported percentages vary from one to $25 \%$. We used the thrombin potential (the ume integral of thrombin formation) in platelet rich plasma to determine whether young stroke patients have a hyper. coagulability. Comparing the thrombin potential in platelet rich plasma to the thrombin potential in platelet poor plasma allows determination of platelei related or plasma based hypercoagulability. Theretore, we delermined the thrombin potential in platelet rich plasma in 41 young stroke patients and in 70 controls. The von Willebrand lactor is a necessary mediator in the mechanism that brings out procoagulant activity in platelets. We therefore also determined platelet derived procoagulant activity and von Willebrand tactor. The thrombin potential in platelet rich plasma was significantly higher in young stroke patients than in controls $(p=0.002)$. Also platelet procoagulant activity and won Willebrand factor were signiflcantly higher in patients than in controls ( $p=0.045$ and $p=0.0006$, respectively). After excluding patients with a plasma based hypercoagulability, patients were divided in three groups on the basis of thrombin potential values in platelet rich plasma. High thrombin potential was significanty associated with stroke. both in the group with the intermediate and in the group will the highest thrombin potential fodds ratio $5.1 ; 95 \% \mathrm{Cl} 1.8-15.1$ and $3.7 ; 95 \% \mathrm{Cl} 1.3$ 10.3. respectively). In a linear regression madel von Willebrand factor was assoctated with platelet procoagulant activity and with the thrombin potential whereas platelet procoagulant activity also was associated with the thrombin potential.

In conclusion: Thrombin generation in platelet rich plasma is elevated in young stroke patients. Comparing the thrombin potential in platelet rich plasma and in platelet poor plasma allowed us to identify patients with platelet related hypercoagulability. Platelet derived procoagulant activity and von Willebrand factor are increased in young stroke patients and both are related to the thrombin potential in platelet rich plasma. This indicates that among the numerous causes that may be behind an imcreased thrombin potential, a high concentration of von Willebrand factor is of significiant importance. Our lindings provide a pathophysiological explanation for the epidemiological observation that relates an increased concentration of von Willebrand factor 10 the occurremce of stroke. 


\section{Introduction}

In chapter 3 we observed that in about one third of young stroke patients thrombin generation in platelet poor plasma is enthanced. Thrombin generation in platelet poor plasma is a laboratory test, created to assess the role of plasmatic clotting factors in establishing a hypercoagulable for in other patients groups a hypocoagulable) state. In vivo thrombin is generated in blood, and the blood cells play an important role in thrombin generation. By far the most important blood cells in this respect are the plateleis. Therefore, thrombin generation in platelet rich plasma (PRP) is one step nearer the physiological reality than thrombin generation in platelet poor plasma. Thrombin, already at low concentrations (about $5 \mathrm{nM}$ ), activates platelets and makes them expose procoagulant phospholipids that in turn facilitate the formation of thrombin by providing the procoagulant phospholipid surface necessary for activation of factor $X$ and prothrombin. ${ }^{6 i}$ 9110010 Measurement of the endogenous thrombin potential (ETP; i.e. the area under the thrombin generation curve) in platelet rich plasma (PRP) and in platelet poor plasma allows determination of hypercoagulability "and differentiates between abnormalities in the plasmatic and the cellular coagulation system. Not only the coagulation factors and the blood platelets, but also von Willebrand factor (WWF) is pivotal in thrombogenesis. ${ }^{704}$ WWF is a necessary mediator in the mechanism that brings out procoagulant aclivity in platelets. Thrombin induces platelet procoagulant activity in a GPIlb/lla dependent process. Fibrin requires GPIb for making the platelet procoagulant. WWF is a necessary cofactor in both mechanisms. ${ }^{704}$ In several studies high WWF was associated with cerebrovascular disease. ${ }^{89} 139$ 140 We hypothesized that increased WWF could play a role in the development of stroke because, by enhancing platelet procoagulant aclivity, il would induce higher thrombin generation, i.e. hypercoagulability. If this hypothesis would be correct, a correlation between WWF and ETP in PRP would be expected, and (a number of) young stroke patients would show high values of both WWF and ETP. Therefore we determined the ETP in PRP and the concentration of WWF in young stroke patients, and in controls. As a correlate to thrombin generation we also measured platelel derived procoagulant activity in serum, i.e. the amount of phospholpid microvesicles, shed by activated platelets. 


\section{Patients, materials and methods}

\section{Patients}

There were 41 consecutiwe patients under age 50 with an ischaemic stroke and 70 healthy volunteers. Precize clinical data of patients and controls are described in chapler 3 .

\section{Materials}

\section{Plasma}

Blood was collected on $0.13 \mathrm{M}$ trisodium citrate; nine parts of blood to one part of citrate solution. An open (non-vacuum) venipuncture was performed in order to avoid platelet activation. The first $\mathrm{ml}$ of blood was discarded to get rid of venipuncture related lissue factor. PRP was obtained by single centrifugation at $250 \times 9$. at $15^{\circ} \mathrm{C}$ for $10 \mathrm{~min}$. The platelet count was adjusted $10300.000 / \mu l$ with homologous platelet poor plasma (centrifuged for 10 min at $1000 \times 9$. Plastic tubes and pipettes were used throughout so as 10 minimize contact activation. All experiments in PRP were carried out within 60 min of venipuncture. Experiments in patients and controls were carried out in parallel.

\section{Serum}

Alter the thrombin generation test was performed the reaction mixture was put on lice, and subsequently centrifuged at $15.000 \times g$ for two min. The supernatant was stored at $-70^{\circ} \mathrm{C}$.

\section{Reagents for thrombin generation}

- Bulfer A consisted of $20 \mathrm{mM}$ Hepes NaOH, $150 \mathrm{mM} \mathrm{NaCl,} 0.5 \mathrm{~g} / \mathrm{Bowne}$ Serum Albumin (BSA; Lot: A-7030, Sigma), pH7.35.

- Buffer B was ine same as buffer A with 20 mM EOTA, pH 7.9

- Chromogenic substrale used for thrombin was S2238: H-D-Phe-Pip-ArgPNA.2HCUl.

- The trigger used for coagulation was $0.1 \mathrm{M} \mathrm{CaCl}$, with recombinant tissue lactor in a concentration of $0.0075 \mathrm{ng} / \mathrm{m}$ : with this concentration of recombinant tissue tactor the clotting time of PPP in plastic tubes is 8 min.

- Stopping lluid was $1 \mathrm{M}$ citric acid.

\section{Methods}

\section{Measurement of thrombin generation in PRP}

Thrombin generation curves were obtained as described in detail by Béguin and Hemker. ${ }^{15 \%}$ In shorl, $480 \mu$ PRP is incubated at $37^{\circ} \mathrm{C}$ with $120 \mu l$ of Buffer A until temperature equilibration $(5 \mathrm{~min})$. Coagulation was initiated at 
$1=0$ by adding 120 w $0.1 \mathrm{M} \mathrm{CaCl}_{2}$ with recombinant lissue factor. The reaction mixture was continuously stired by a small spatula and $10 \mu 1$ subsamples were drawn at equally spaced intervals of $30 \mathrm{sec}$ and diluted in prewarmed $\left(37^{\circ} \mathrm{C}\right)$ cuvettes containing 490 wl of Bufter $\mathrm{B}$ with 200 uM 52238 . The reaction was stopped after 2 min by adding $300 \mu$ of $1 \mathrm{M}$ citric acid. As soon as the reaction mixture coagulated, the clot was wound on the spatula and removed. The optical density (OD) was read at $405 \mathrm{~mm}$. The spectrophotometer as well as the subsampling and stopping pipette were connected to a personal computer that calculated the increase in OD per minute from the $\mathrm{OD}$ and the moment of subsampling and stopping. The amidolytic values were converted into nM thrombin via a standard calibration curve of active site titrated human $\alpha$-thrombin. The lag time of thrombin formation is defined as the moment at which the thrombin concentration fises from a $0-5 \mathrm{nM}$ level to a $10 \mathrm{nM}$ level.

\section{Calculation of the thrombin potential}

The ETP is defined as the area under the thrombin generation curve. 825050460 The ETP is the product of thrombin concentration, and the time that it acts. ${ }^{9}$ 150 It indicates how much substrate the thrombin generated in plasma can potentially convert. The ETP can not be read directly from the optical density that develops during the experiment, because thrombin is not the ony enzyme that converts the substrate. Part of the free thrombin is irreversibly bound to a2-macroglobulin, thereby losing its biologicat, but not its amidolytic activity. Therefore, the course of the optical density has to be divided in the part due to the activity of free ltrombin, and the part due to the a2-macroglobulinuthrombin complex. Because the velocily of the formation of the latter complex is proportional to the amount of free thrombin, the ETP can thus be calculated by a mathematical procedure. 153 The ETP in PAP Is expressed in percentages of the mean walue in the control group

\section{Platelet derived procoagulant activity in serum}

The serum which was obtained from the reaction mixture alter the thrombin generation test was pertormed, was diluted 6.67 limes in buffer A (18 fll serum: 102 il buffer A). $50 \mu$ of subsample was incubated for $4 \mathrm{~min}$ al $37^{\circ} \mathrm{C}$ with an assay mixture, containing $0.87 \mathrm{nM}$ lactor $\mathrm{Xa}, 21 \mathrm{nM}$ lactor $V a$ and 24 $\mathrm{mM} \mathrm{CaCl}$, in buffer $\mathrm{A}$. At $\mathrm{t}=050 \mu$ prothrombin $(6 \mathrm{mM})$ was added. Alter 4 min, $10 \mu l$ of subsample was taken to a cuvette containing $465 \mu$ bulfer $B$. The amount of fmrombin formed was calculated from the continuous measurement of absorbance change at $405 \mathrm{~nm}$ atter the addition of 25 w of $\$ 2238$ (4mM). The amount of thrombin formed depends on the activity of prothrombinase. The activity of prothrombinase is dependent on the amount of procoagulant phospholipids. These phospholipids are exposed by microvesicles, shed by the activated platelets in the reaction mixture. 
Therefore the amount of thrombin lormed is a measure of the platelet derived procoagulant aclivity.

Platelet derived procoagulant activity was determined in 34 patients and 52 controls.

\section{von Willebrand factor}

WWF antigen was determined with an enzyme linked immuno-absorbent assay (ELISA) kit from Diagnostica Stago, Boehringer, Mannheim. WFwas determined in all patients and in 65 controls.

\section{Statistical evaluation}

Variables are presented as median and 25 and 75 percentile. As discussed in chapter 3,14 of the 41 patients had an elevation of ETP in platelet poor plasma (PPP), so in these patients an abnormalily of the plasmatic coagulation system was suspected (fig 4.1 ). The remaining patient group $(n=27)$ was categorized into three groups using cutoff points at the 33th and 66 th percentile of the ETP in PRP. We used the Mann-Whitney test to analyze differences in distribution of continuous variables between groups. We analyzed relationships between ETP in PRP, platelet derived procoagulant activity, WWF and fibrinogen using linear regression analysis. To check whether relationships were different for patients and controls, we also performed linear regression analysis separately for patients and controls Resulis of linear regression analysis are presented in regression coefficient with $95 \%$ confidence intervals $(95 \% \mathrm{Cl})$. We analyzed the association between stroke and ETP in PRP by means of odds ratios (OR) with $95 \%$ confidence intervals $(\mathrm{Cl})$ with a logistic regression model.

\section{Results}

Median values (25.75 percentile) of ETP, platelet derived procoagulant acivity, WWF fibrinogen and antithrombin III of the patients and of the controls are shown in lable 4.1. The ETP in PRP is expressed in percentage of the control group (median $515(25,75$ percentile: 449,553$)$ ). The ETP in PRP was significantly higher in young stroke patients than in controis $(p=0.002)$. Also platelet derived procoagulant activity $(p=0.045)$, wF $(p=0.0006)$ and fibrinogen $(p=0.0007)$ were higher in patients tham in controls. 


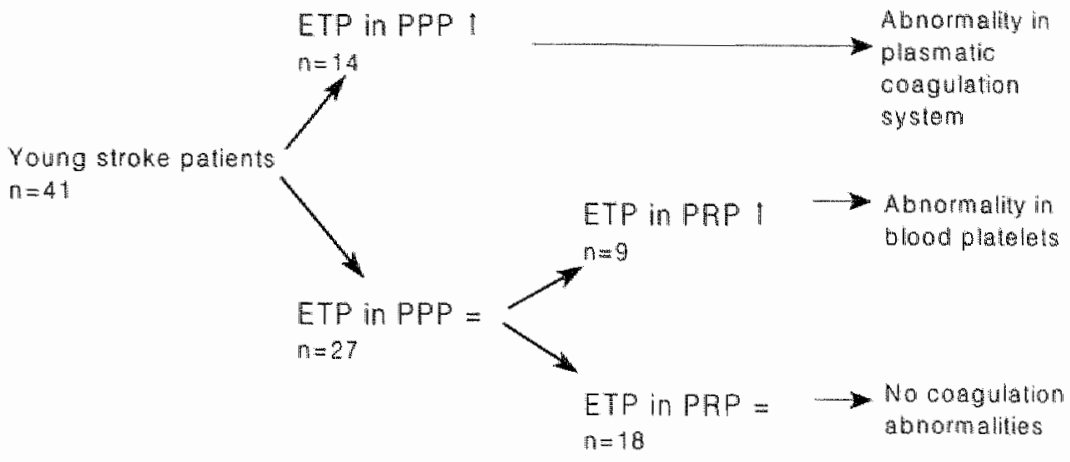

Figure 4.1. Flow diagram of thrombin potential (ETP) in platelet poor plasma (PPP) and in platelet rich plasma (PRP) (1: enhanced: = : normal).

Patients with no abnormalities in the ETP in platelet poor plasma $(n=27)$ were divided in three groups on basis of the ETP values (33th and 66th percentile). The results of these separate groups are shown in table 4.2. The group with the highest ETP (group 1) had (of course) a significant higher ETP $(p=0.0003)$, but also a higher WWF $(p=0.0119)$, platelet derived procoagulant activity ( $p=0.0082)$, and fibrinogen $(p=0.0223)$ than controls. In the group with a moderate increase in ETP (group 2) both ETP and wWF were higher than in controls $(p=0.0009$ and $p=0.0403$, respectively). Platelet derived procoagulant activity in this group was higher, though not stalistically significant. The group with the lowest ETP in PRP (group 3) did not differ from the controls. With the combined results of the ETP in PPP (chapter 3) and in PRP patients can be divided into a group with suspecled abnormalities in the plasmatic coagulation system $(n=14)$, a group with platelet related hypercoagulability $(n=9)$, and a group with no coagulation abnormalities ( $n=18$ ) (fig. 4.1).

ETP in PRP was significantly associated with stroke, both in the group with intermediate and high ETP (odds ratio 5.1 and $3.7 .95 \% \mathrm{Cl} 1.8-15.1$ and 1.310.3, respectively). In a regression model with ETP as dependent and WWF as independent variable, VWF was significantly associated with the ETP (fig. 4.2; table 4.3) in a regression model, platelet derived procoagulant activity was strongly associated with the ETP (fig.4.3). Fibrinogen level was not associated with the ETP in PRP. In a regression model with platelet derived procoagulant activity as dependent variable. WWF was a significant predictor of elevation of platelet derived procoagulant activity. There were no 
Table 4.1. Median values (25.75 percentiles) af ETP in PRP, platelet procoagulant activity, WWF, hbrinogen and antithrombin $1 \mathrm{ll}$ in young stroke patients and controls.

\begin{tabular}{llll}
\hline & $\begin{array}{c}\text { Young stroke patients } \\
n=44\end{array}$ & $\begin{array}{c}\text { Controls } \\
n=70\end{array}$ & p-walue \\
\hline ETP in PRP & $111(104-188)$ & $102(89-110)$ & 0.002 \\
platelei procoagulant activity & $90(69-106)^{*}$ & $79(65-88)^{*}$ & 0.045 \\
WWF & $102(87-118)$ & $26(74-100)^{\circ}$ & 0.0006 \\
fibrinogen & $3.2(2.8-4.0)$ & $28(2.5-3.2)$ & 0.0007 \\
antithomion ill & $106(98-109)$ & $108(104-111)$ & $\mathrm{NS}$ \\
\hline
\end{tabular}

" not determined in all subjects, see the methods section

significant differences between patients with territoriall and lacunar infarcts, with respect to ETP in PRP, platelet derived procoagulant activity and WWF. There was no relationship between ETP in PAP and age, hypertension or other vascular risk factors.

\section{Discussion}

The ETP is an overall assay of the blood coagulation system. With the use of the ETP in PRP. the interplay between blood platelets and the plasmatic coagulation factors under in virro conditions that approach the in wivo conditions, can be investigated. ${ }^{152}$ Measuring the ETP in PRP and in PPP allowed us to exclude hypercoagulability in about $50 \%$ of young stroke patients, thereby limiting the need for further extensive laboratory investigations in search for specific coagulation abnormalities in these

Table 4.2. Results in median (25-75 percentiles) of ETP in PRP, platelet derived procoagulant aclivity (PPA). WF and fbrimogen in the patient subgroups and in controls

\begin{tabular}{|c|c|c|c|c|}
\hline & $\begin{array}{l}\text { Controls } \\
n=70\end{array}$ & $\begin{array}{l}\text { Group } 1 \\
\text { (EFP — 18) } \\
n=9\end{array}$ & $\begin{array}{l}\text { Group } 2 \\
(E T P 111-117) \\
n=10\end{array}$ & $\begin{array}{l}\text { Group } 3 \\
(E \pi P \text { s } 110) \\
n=8\end{array}$ \\
\hline ETP An PRP & $\begin{array}{l}102 \\
(89-110)\end{array}$ & $(1194134)$ & $\begin{array}{l}113 \\
(111-115)\end{array}$ & $\begin{array}{l}94 \\
(8+-103)\end{array}$ \\
\hline PPA & $\begin{array}{l}79 \\
(65.89)^{*}\end{array}$ & $\begin{array}{l}107 \\
(78-117)^{*}\end{array}$ & $\begin{array}{l}91 \\
(72 \cdot 99)^{\circ}\end{array}$ & $\begin{array}{l}50 \\
(45-100)^{n}\end{array}$ \\
\hline$v^{W W F}$ & $\begin{array}{l}86 \\
(74-100)^{x}\end{array}$ & $\begin{array}{l}102 \\
(92-138)\end{array}$ & $\begin{array}{l}100 \\
(91-113)\end{array}$ & $\begin{array}{l}97 \\
(73-124)\end{array}$ \\
\hline fibrinogen & $\begin{array}{l}28 \\
(2.5-3.2)\end{array}$ & $\begin{array}{l}33 \\
(3.0-3.8)\end{array}$ & $\begin{array}{l}3.5 \\
(2.7-3.9)\end{array}$ & $\begin{array}{l}29 \\
(2.2 \times 32)\end{array}$ \\
\hline
\end{tabular}

" not determined in all subjects, see the methods section 


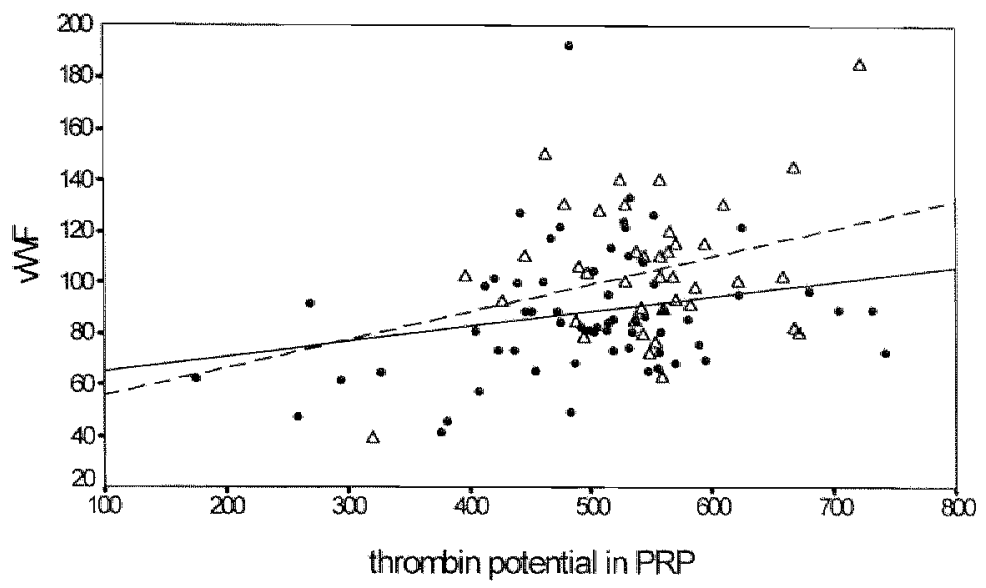

Figure 4.2. ETP in PRP and WWF in young stroke patients $(\Delta)$ and controls $(\cdot)$. The regression lines of WWF on the ETP are drawn for patients ( ....) and for controls $(-)$.

Table 4.3. Results of linear regression analysis (regression coefficient $(95 \%$ CI) of ETP in PRP, platelet derived procoagulant activity (PPA) and WWF in controls, in young stroke patients, and in the whole group of subjects.

\begin{tabular}{llllll}
\hline & Regression model & Controts & Patients & Overall \\
\hline 1 & dependent & PPA & 0.16 & 0.23 & 0.23 \\
& independent & WWF & $(-0.06-0.39)$ & $(-0.07 \cdot 0.53)$ & $(0.05-0.40)^{*}$ \\
2 & dependent & ETP & 2.07 & 2.05 & 2.11 \\
& independent & PPA & $(0.83-3.31)^{* *}$ & $(1.08-302)^{* *}$ & $(1.32 .2 .89)^{* *}$ \\
3 & dependent & ETP & 0.99 & 0.91 & 1.16 \\
& independent & WWF & $(-0.03-2.03)$ & $(0.02 .1 .79)^{\circ}$ & $(0.49-1.84)^{* * *}$ \\
\hline
\end{tabular}

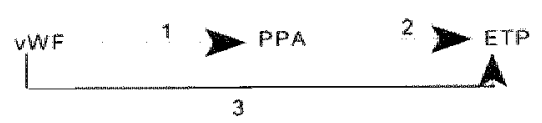

Presumed relationships between WWF. PPA and ETP in PAP.

$$
\begin{array}{ll}
* \quad & p<0.05 \\
* & P<0.01 \\
* & P<0.001
\end{array}
$$




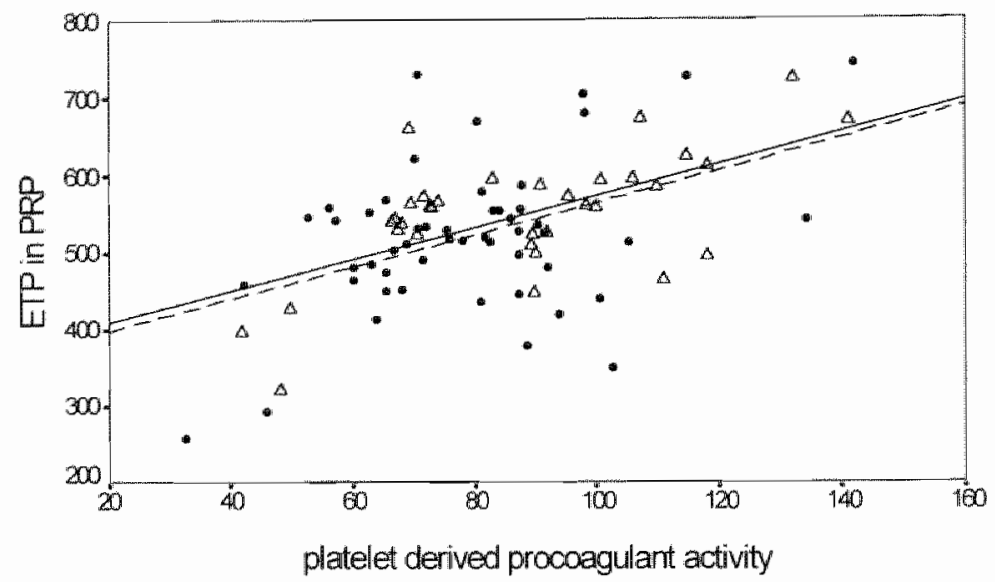

Figure 4.3. ETP in PRP and platelet derived procoagulant acivily in young stroke patients $(\alpha)$ and in controls (-). The regression lines of platelet procoagutant activily on the ETP are drawn for patients (---) and for controls ( - - ).

palients. With the ETP it is possible to establish any coagulation abnomality, and to differentiate whether such abnormality is due to the plasmatic coagulation system or related to the blood platelets. More than hall of our patients appeared to have a hypercoagulability. In aboul one third of the patients the hypercoagulability was likely to be due to an abnormality in the plasmatic coagulation system (chapter 3 ). whereas in about a quarter it was likely to be induced by the blood platelets (fig 4.1). We found am enhanced ETP in PRP of young stroke patients when compared to controls. High ETP in PAP (both the intermediate and the high values) appeared to be a predictor for stroke. Our resulls indicale a far more important role of coagulation disorders in the development of cryptogenic stroke in young patients than so lar assumed. With the ETP it is possible lo identify coagulation abnormalites. and to differentiate whether such abnomality is due to the plasmatic coagulation system or related lo the blood platelets. Once this is known. one is able 10 choose a more rational appraoch to secondary thrombosis prevention, i.e. antiplatelet or anlicoagulant therapy. Furthemore, a high ETP in platelet poor plasma indicales that it is worthwile to search tor abnomalities in the plasmatic coagulation system, whereas a high ETP in PRP suggests searching in the as yet hardly explored field of platelet based hypercoagulability.

When a haematologic abnomality is identified after stroke, the haematologic disorder can not be assumed to have antedated the stroke, and can be a consequence rather than the cause of stroke. Support for an antecedent, causal role of the haematologic disorder includes its persistence 
after the acute phase of stroke. For this reason we tested our patients at least 3 months after the ischaemic event. Therefore, we believe that our findings reflect the premorbid state of the patients and allow the conclusion that hypercoagulability plays an important role in the development of stroke in a significant number of patients.

Measurement of thrombin formation in PRP is highy informative because it includes the influence of the blood platelets and therefore represents the situation in wivo better than thrombin generation in PPP does. However, ofher blood cells, the vessel wall, and flow characteristics which are present in Wivo, do not play a role in the thrombin generation test in PRP. Nevertheless, the ETP reveals coagulation abnormalities in young stroke patients that are not detected by other tests. In its present form however, it is nol an easy test that can be applied on a routine basis. One test requires two working hours by experienced technicians.

Under the experimental circumstances of the thrombin generation test in PRP procoagulant phospholipids are the rate limiling factor for thrombin generation and not the factors $V$ or $V / 11 .{ }^{15 i}$ Therefore, the moment of the burst of thrombin generation is the moment at which the platelets massively expose their procoagulant surface. In this process platelets also shed procoagulant microvesicles, that remain in the serum after the experiment. The coupling of these processes is reflected by the correlation between ETP in PRP and platelet derived procoagulant activity, as seen in our patients. It is not a priori clear in what way the cause-effect relationships between thrombin generation and platelet derived procoagulant activity go. In those patients with a high ETP in PPP, the high Hevels of thrombin may promote high levels of platelet derived procoagulant activity. This mechanism may also play a role in PRP, but there the reverse reaction may be more plausible: platelets that shed more procoagulant microvesicles may cause more thrombin 10 be generated. Theretore, increased platelel derived procoagulant activity may be the cause of hypercoagulability in a subgroup of young stroke patients. Other investigators have also reported a sustained increase in platelet activation in patients with cerebral ischaemia. ${ }^{100}$

Currently it is unclear what aberrations of the intraplatelet mechanisms lead 10 an increased procoagulant funclion of the platelet. Platelet activation is an extremely complicated process ${ }^{165} .198$ in which many functions are possible sites of congenital or acquired disturbances. From the type of studies as reported here, it may in the future be possible to deline individuals or families in whom specific pathogenic mechanisms can be identified

A factor contributing to the procoagulant reaction of the platelel, is WWF. WF mediates the interaction between fibrin and platelets through GPlb 136 and this interaction is one of the pathways that makes plateleis procoagulant. $^{104}$ Binding of WWF to GPllb/lla receptors on the platelet membrane plays a role in platelet aggregation ${ }^{128} 135$ and also contributes to 
the procoagulant reaction of the platelet ${ }^{7}$ So, WWF appears as a necessan mediator to express platelet procoagulant activity via GPllb/lla as well as via GPIb and fibrin, and turns out to be indispensable for thrombin generation in PAP." Earlier studies demonstrated a correlation between WWF and cerebrovascular disease. \& 39 .:0 Catto also found a relationship belween WW, stroke mortality and stroke type (higher level of WW among patients with large vessel disease). WWF was increased in our young stroke patients. We also found a significant correlation between ETP in PRP and WWF, and between platelet derived procoagulant activity and WWF. Obviously, WWF is not merely a marker of endothelial damage, but plays an essential role in coagulation through its effect on platelet activation. Our findings therefore provide a pathophysiological explanation for the epidemiological obserwation that relates increased concentration of WW lo the occurrence of stroke and to the increased mortallity in stroke survivors. 89

Fibrinogen is an independent risk factor for stroke and myocardial infarction. 14.16 Fibrin induces platelet procoagulant activily. which in turn leads to production of more thrombin and eventually to the formation of even more fibrin. ${ }^{9}$ 10 This circle may be more vicious when fibrinogen level is high, which might explain the link between fibrinogen and stroke. Fibrinogen was elevaled in out young stroke patients, but there was no correlation between fibrinogen and ETP in PAP. Absence of fibrinogen raises the thrombin generation curve in PPP. This can be explained by the absorption of thrombin by the fibrin formed during coagulation. During a thrombin generation experiment the clat is wound on a spatula and removed. thereby reducing the effect of fibrin on the thrombin generation. This may be one of the reasons thal we did not find a relationship between fibrinogen and ETP in PRP.

In conclusion: Thrombin generation is elevated in young patients with cryptogenic stroke. In about a quarter of the patients the hypercoagulability is related lo the blood platelets, and determination of the ETP in PRP can be used to detect such platelet related hypercoagulability. Platelet derived procoagulant aclivity and WWF are increased in young stroke patients and both are related to ETP in PRP. This identifies a high concentration of WWF as an important one among the numerous possible causes for increased thrombin generation in PRP. 
Chapter

Influence of aspirin and fixed low-dose oral anticoagulation on thrombin generation in young stroke patients and in healthy volunteers 


\section{Abstract}

Antiplatelet therapy has limited efficacy in the secondary prevention of stroke. Theretore, there is an urgent need for a more potent therapeutic modatity. Il would be advantageous if patients with hypercoagulability either due to the plasmatic coagulation system or related to platelels could be separately identified, as this may eventually allow a more rational prescription of a preventive drug. It is concevable that a decrease in the thrombin generation, induced by aspirin or fixed low-dose oral anticoagulants, may lower the risk of thrombotic events in patients. Therefore, we determined the thrombin potential in platelet rich plasma and in platelet poor plasma in 12 healthy volunteers and in 41 young stroke palients without medication, alter two weeks use of aspirin ( $30 \mathrm{mg} / \mathrm{day}$ ), and after two weeks use of fixed low-dose oral anticoagulants (phenprocoumon $0,75 \mathrm{mg} / \mathrm{day}$ ). In the controls there was a mild but significant decrease (ca. $8 \%$ ) of the thrombin potential in platelet rich plasma after wo weeks on aspirin $(p=0.02)$, whereas in the patients such an effect was seen only in the subgroup with platelet related hypercoagulability $(\rho<0.01)$. In the patients with plasma based hypercoagulability the thrombin polential in the extrinsic pathway decreased after aspirin use $(p=0.005)$. Platelet procoagulant activity decreased in our young stroke patients after aspirin treatment $(p=0.05)$ Fixed low-dose phenprocoumon in the contrals decreased the thrombin potential only in the extrinsic pathway $(p<0.05)$, which eftect was also seen in the patients $(p=0.03)$. Also in the patient subgroup with platelet related hypercoagulability thrombin generation in platelet rich plasma decreased after phenprocoumon.

In conclusion: Aspirin modulates the hypercoagulable state as measured by the thrombin potential in young stroke patients, especially in those pattients with platelet related hypercoagulability. However, it has only a mild effect on decreasing thrombin generation. We found no laboratory support for a potential higher effectiveness of fixed low-dose phenprocoumon compared to aspirin on the prevention of llinomboembolic events. 


\section{Introduction}

Secondary prevention is an important aspect in stroke managenent. Up till now, in most patients with ischaemic stroke or transient ischaemic attack (TIA) of presumed arterial origin antiplatelet therapy with aspirin is used. This therapy has limited, but clinically significant efficacy in the prevention of vascular events (stroke, myocardial infarction, or death from a vascular cause). In patients with a prior stroke or TIA antiplatelet therapy results in an absolute risk reduction of non-fatal stroke of $2 \%(8.2 \%$ in treated patients against $10.2 \%$ in controls). ${ }^{10}$ 54 There has been some discussion on the dose of aspirin to be used in secondary prevention of vascular events following TIA or stroke. ${ }^{55} 56$ As no dose-effect relation has ever boen dernonstraled clinically, the dose in use depends on various factors. In the Netherlands most patients are treated with low-dose aspirin ( $30 \mathrm{mg}$ ), because a Dutch study showed no significant difference in efficacy of $30 \mathrm{mg}$ or $283 \mathrm{mg}$ of aspirin. ${ }^{57}$

Standard dose oral anticoagulation (with a prothrombin-time in International Standardized Ratio (INR) of 2-4) has only been proven beneficial in patients with cardioembolic stroke. In patients with TIA or minor stroke of presumed arterial origin however standard dose oral anticoagulation carries a high risk of serious bleeding complications (mostly intracerebral haemorrhage). In a recent study comparing aspirin and standard dose oral anticoagulation in non-cardioembolic stroke, patients on anticoagulants had an odds of almost 20 of dying from bleeding complications, compared to those on aspirin. "

Low-dose anticoagulants might be an attractive alternative for patients. with non-cardioembolic stroke. It seems likely that this would be associated with a lower bleeding risk than anticoagulants al standard inlensily, and it might also require less frequent laboratory monitoring. Trealment wilh fixed low-dose warfarin ( $1 \mathrm{mg} /$ day) reduced the incidence of deep vein thrombasis aiter major gynaecolagical surgery, ${ }^{12}{ }^{13}$ although the combination of aspirin and fixed low-dose wartarin had no additional effect over aspirin alone in patients after myocardial infarction. ${ }^{15}$ Low-inlensily warfarin (INR below 2.0) has no effect in the prevention of stroke in patients with non-rheumatic atrial fibrillation. ${ }^{14} 189190$ Obviously, the clinical efficacy of low-dose oral anticoagulation has not clearly been demonstrated.

Theoretically, patients with presumed platelet induced hypercoagulability would benefit from antiplatelet therapy, whereas a plasma based hypercoagulability would be better treated by damping the plasmatic coagulation system. As described in the previous chapters, the thrombin potential (ETP) offers the opporiunity to distinguish between plasma or platelet based hypercoagulability. ${ }^{150}$ ist 160 The thrombin potential is a sensitive screening parameter for the coagulation system and for the 
anticoagulant effect of medication. The ETP decreases to between 15 and $35 \%$ of normal by standard dose oral anticoagulation (INR 2.5 4.0) and by heparin administration. ${ }^{100}$

Neither fixed low-dose oral anticoagulants nor aspirin affects the standard clotting tests used to check antithrombotic treatment. Nevertheless, for effective prophylaxis an eifect on the haemostatic function of the blood is likely to be required. It is conceivable that a decrease in the ETP, induced by aspirin or fixed low-dose oral anticoagulants, accompanies an effect in the prevention of thrombotic events in patients. Therefore, we investigated whether we could demonstrate a decrease in thrombin generation with the aid of the thrombin generation test. We determined ETP in platelet rich plasma and in platelet poor plasma in healthy volunteers and in young stroke patients without medication, atter the use of aspirin, and after the use of fixed low-close oral anticoagulants.

\section{Subjects, materials and methods}

\section{Subjects}

Twelve healthy volunteers ( 4 males, 8 females) participated in the study. Mean age was $32.8( \pm 6.1)$ years. Four of the women used aral contraceptives. Five subjects had a first degree relative with vascular disease. Blood samples were taken after a period without medication, after two weeks use of $30 \mathrm{mg}$ aspirin a day, and after at least two weeks use of $0.75 \mathrm{mg}$ phenprocoumon a day.

There were 41 consecutive patients under age 50 with ischaemic stroke (three patients had a TIA). The data of these patients are described in detal in chapter 3.

Blood samples were taken after at least two weeks without aspirin, after two weeks use of $30 \mathrm{mg}$ aspirin a day (most patients used aspirin since much longer), and after at least two weeks use of $0.75 \mathrm{mg}$ phenprocoumon a day.

\section{Materials}

The materials used for the determination of the thrombin potential, platelet derived procoagulant activity and the thrombomodulin test are described in chapter 3 and in chapter 4

\section{Methods}

The measurement of thrombin generation in platelet poor plasma and the thrombomodulin test are cescribed in chapter 3 . The determination of the 
ETP in platelet rich plasma and the platelet derived procoagulant activity are described in detail in chapter 4.

\section{INR, Factor $\| l, V I I$ and $X$}

Prothrombin-time in INR was determined before medication, and after the use of aspirin and phenprocoumon in the twelve healthy wolunteers. In the young stroke patients we determined prothrombin-time in INR without medication and after treatment with phenprocoumon. In the volunteers also Factor II. Factor VII and Factor X were determined without medication, and after the use of aspirin and phenprocoumon. Factor II, VII and $X$ were measured using a factor assay procedure with Factor Deficient Plasma (Organon Teknika GmbH, Eppelheim, Germany).

\section{Figure 5.1}

To establish the relationship between ETP and INR we collected plasma from patients treated with oral anticoagulation at the Maastricht Thrombosis Service (head Dr. H.L.L. Frank). Plasma pools of $10 \mathrm{ml}$ were made, each from $1 \mathrm{mil}$ of individual plasma, selected to fall in a defined 0.1 INR interval. in this way 72 pools were obtained over the range of $0.9-3.2$ INR. Of each of these pools the INR and the extrinsic ETP were determined. Pools were used to compensate for individual variation in clotting factors.

\section{Statistical evaluation}

Results are presented as median and 25 and 75 percentile. We used the Mann-Whitney test to analyze differences in distribution of continuous variables between groups and the Wilcoxon test to analyze paired samples. To analyze whether the relation between ETP in PRP and medication is mediated by platelet derived procoagulant activity, we used a linear regression model. The patient group was divided into three subgroups as described in chapter 3 and chapter 4 (fig. 4.1); patients with an ETP in PPP above the 66th percentile were considered to have an elevation of the ETP in PPP (group 2; $n=14$ ). Of the remaining 27 patients those with an ETP in PRP above the 66 th percentile were considered to have an elevation of the ETP in PRP (group $3 ; n=9$ ). The remaining patients were considered to have no clear abnormalities in coagulation as measured by the ETP (group $: n=18$ ).

\section{Results}

Median values of the measurements in the controls without medication, alter aspirin, and after phenprocoumon are listed in table 5.1. In the controls there was a mild but significant decrease (ca. $8 \%$ ) of ETP in PRP after lwo weeks on aspirin $(p=0.02)$, but not atter two weeks on phenprocoumon. ETP in PPP 
only decreased in the extrinsic system after two weeks on phenprocoumon $(\rho=0.05)$. ETP in PPP did not change significantly after aspirin use. There was no significant change after use of medication in lag-phase, in platelet derived procoagulant activity or in percentage inhibition after addition of thrombomodulin. Prothrombin-time ratio did not change significantly neither after the use of aspirin nor after the use of phenprocoumon. Onlly factor $X$ decreased significantly after the use of phenprocournon $(p=0.03)$ (table 5.1). Platelet derived procoagulant activity was significanily associated with ETP in PRP (regression coefficient 1.35; $95 \%$ confidence intervals $0.04-266$ ). Median values of the measurements in 41 young stroke patients withoul medication, alter aspirin, and after phenprocoumon are shown in table 5.2. ETP in PRP in our young stroke patients did not change significantly with aspirin, nor with phenprocoumon. ETP in the extrinsic coagulation system decreased significantly, both with aspirin and phenprocoumon $(p=0.005$ and $p=0.03$, respectively). In the intrinsic system no changes were observed after medication. Platelet derived procoagulant activity decreased after administration of aspirin $(p=0.05)$, but not after phenprocoumon. The median of the INR in the patients was $0.95(0.92-1.00)$ before treatment with phenprocoumon, and $0.97(0.92-1.04)$ after treatment. There was no significant difference in INR before and after treatment with low fixeddose oral anticoagulants.

Table 5.1. Median values (25-75 percentile) of the measurements whthout medication, after aspirin use, and after phenprocoumon use in welve heatiny volunters

\begin{tabular}{|c|c|c|c|}
\hline & Without medication & Aspirin & Phenprocoumon \\
\hline ETP in PAP & $92(85-107)$ & $84 \quad(75-89)^{\prime \prime}$ & $96(82-101)$ \\
\hline ETP extrinsic & $108 \quad(100-120)$ & $108 \quad(97-115)$ & $(100-112)^{r}$ \\
\hline ETP intrinsic & $99(92-113)$ & $100 \quad(92-109)$ & $(90-107)$ \\
\hline PPA & $73 \quad(56-104)$ & $78(6 \pi-104)$ & $78(66-91)$ \\
\hline $\mathrm{TM}$ & $43(39-49)$ & $46(38-48)$ & $43(40-48)$ \\
\hline $\mathrm{FHI}$ & $103(98-117)$ & $103 \quad(97-109)$ & $102 \quad(98-106)$ \\
\hline FVll & $114(88-136)$ & $115(88-124)$ & $107 \quad(86-120)$ \\
\hline$F X$ & $110 \quad(97.128)$ & $104 \quad(99-126)$ & $102(94-120)$ \\
\hline INR & $097(0.94-1.08)$ & $1.00(0.95-1.06)$ & $0.99(0.94 \cdot 1.08)$ \\
\hline
\end{tabular}

" $p<0.05$

Ellp endogenous thombin potental, PPP platelet rich plasma. PPA plateler derved procodgutan achity. TMl: percentage inhibition of the ETP after addition of thombonodulin. Fll: prothrombin, FVI: tactor WII, FX: factor $X$, INR: protmombinme in Intermationa Siandardzed Ratio. 
Table 5.2. Median values (25-75 percentile) of ETP in PRP and PPP (extrinsic and intrinsio system) and platelet derived procoagulan actwity (PPA) in young stroke patients without medication, after aspirin, and atter phenprocoumon.

\begin{tabular}{|c|c|c|c|c|c|c|}
\hline \multirow[b]{2}{*}{ ETP in PRP } & \multicolumn{2}{|c|}{ Without medication } & \multicolumn{2}{|c|}{ Aspirin } & \multicolumn{2}{|c|}{ Pherporoumon } \\
\hline & 111 & $(103-118)$ & 108 & $(97-114)$ & 107 & $(104.112)$ \\
\hline ETP extrinsic & 106 & $(93-121)$ & 103 & $(91-114)^{*}$ & 101 & $(88-113)^{\mathrm{n} *}$ \\
\hline ETP intrinsic & 105 & $(87-122)$ & 102 & $(80-119)$ & 100 & $(86-118)$ \\
\hline PPA & 90 & $(69-106)$ & 73 & $(59-98)^{2 \times x}$ & 85 & $(69-104)$ \\
\hline $\begin{array}{ll}* & p<0.01 \\
* & p<0.05 \\
* * \quad p=0.05\end{array}$ & & & & & & \\
\hline
\end{tabular}

The results of the three patient subgroups are listed in table 5.3. In the patients with no elevation in ETP in PRP or PPP (group 1) no influence of medication was found. In the patients with an elevation of ETP in PPP (group 2), aspirin significantly reduced ETP in the extrinsic coagulation system. There was no influence of phenprocoumon on the ETP in PPP, neitther in the extrinsic, nor in the intrinsic coagulation system. In the group with platelel related hypercoagulability, i.e. the group with an elevation of ETP in PRP only (group 3) both aspirin and phenprocoumon significantly reduced ETP in PRP $(10 \%$ and $11 \%$, respectively). Platelet derived procoagulant activity decreased also, but not significantly.

Figure 5.1 shows the relation between INR and ETP as obtained in 100 plasma pools at different INR levels.

\section{Discussion}

\section{Aspirin}

In the healthy volunteers we found a decrease of thrombin generation in platelet rich plasma as measured by the ETP after two weeks administration of aspirin, whereas in our young stroke patients we lound no signilicant influence of aspirin on thrombin generation as measured by the ETP in PRP or PPP. However, within the patient group there were remarkable differences in influence of aspirin on thrombin generation. Based on whether the ETP was elevated or not, we distinguished three patients groups: group 1 with no abnormalities in thrombin generation, group 2 with an elevation of ETP in PPP. and group 3 with an elevation of ETP in PRP (fig. 4.1). Patients with platelet related hypercoagulability (group 3) had a decrease of ETP after aspirin use, although ETP did not return to normal values. Others also found a decrease of thrombin generation with aspirin. ${ }^{152}$ ig 19 another study high 
Table 5.3. Median vaues (25-75 percentile) of ETP and platelet derved procoagulant activity (PPA) in the different subgroups of young stroke patients, without medication, atter aspinin, and atter phenprocoumon.

Group 1. Patients in whom no abnomalites in coagulation could be detecled (n=18)

\begin{tabular}{|c|c|c|c|c|c|c|}
\hline \multirow[b]{2}{*}{ EIP in PRP } & \multicolumn{2}{|c|}{ Without medication } & \multicolumn{2}{|c|}{ Aspirin } & \multicolumn{2}{|c|}{ Phenprocoumon } \\
\hline & 111 & $(94-13)$ & 108 & $(94-113)$ & 107 & $(95-113)$ \\
\hline ETP exirinsic & 96 & $(80-108)$ & 96 & $(83-106)$ & 94 & $(82-104)$ \\
\hline Erp intrinsic & 98 & $(78-105)$ & 97 & $(86-103)$ & 98 & $(81-105)$ \\
\hline PPA & 81 & $(64-99)$ & 71 & $(62-101)$ & 85 & $(59-92)$ \\
\hline
\end{tabular}

Group 2. Pattents with a probable abnornality of the plasmatic coagulation system $(n=14)$

\begin{tabular}{lllll}
\hline & Withoutmedication & Aspirin & Phenprocoumon \\
\hline ETP im PRP & $107(101-111)$ & $107(96-114)$ & $109(99-115)$ \\
ETP extrinsic & $122(121-127)$ & $115(110-129)^{*}$ & $116(112-130)$ \\
ETPintrinsic & $128(121-145)$ & $124(112-138)$ & $129(110-156)$ \\
PPA & $86(68-91)$ & $69(59-101)$ & $71(63-101)$ \\
\hline
\end{tabular}

Group 3. Palients with platelet related hypercoagulability $(\mathrm{r})=9$ )

\begin{tabular}{|c|c|c|c|c|c|c|}
\hline \multirow[b]{2}{*}{ ETP in PRP } & \multicolumn{2}{|c|}{ Without medication } & \multicolumn{2}{|c|}{ Aspirin } & \multicolumn{2}{|c|}{ Phenprocoumon } \\
\hline & 124 & $(119-134)$ & 111 & $(94,-13)^{*}$ & 110 & $(105-113)^{* *}$ \\
\hline EIP extrinsic & 97 & $(91-105)$ & 96 & $(87-102)$ & 93 & $(83-99)$ \\
\hline ETP irntrinsic & 92 & $(83-104)$ & 94 & $(78-110)$ & 93 & $(79-98)$ \\
\hline PPA & 107 & $(78.117)$ & 89 & $(53-94)$ & 96 & $(83-113)$ \\
\hline
\end{tabular}

* $p<0.05$

$* \quad p<0.01$

comcentrations of aspirin had no influence on thrombin peak concentration. but did prolong the lagmphase. ${ }^{192}$ Thus, aspirin has a modest intluence on thrombingeneration in PRP, boh in controls and in subgroups of patients.

There is a marginal effect of aspirin on thrombin generation in PPP in the patient group. In the patient subgroups the same effect of aspirin is only seen in those patients with a plasma based hypercoagulabilty. The influence of aspirin on the thrombin generation in PPP may be explained by the small anivitamin $K$ effect that accompanies aspirin intake. ${ }^{193} 197$ As aspirin is onty a weak vitamin $K$ antagonist, it was thought to bring aboul this effect only at very high dosages. Our resulls indicate that intake of a small dose over a longer period of time (most of our patients used aspirin for months, or even years) may still have this effect. Others also described that chronic treatment with aspirin reduced the total amount of thrombin formed. ${ }^{19}$ "The defirite 


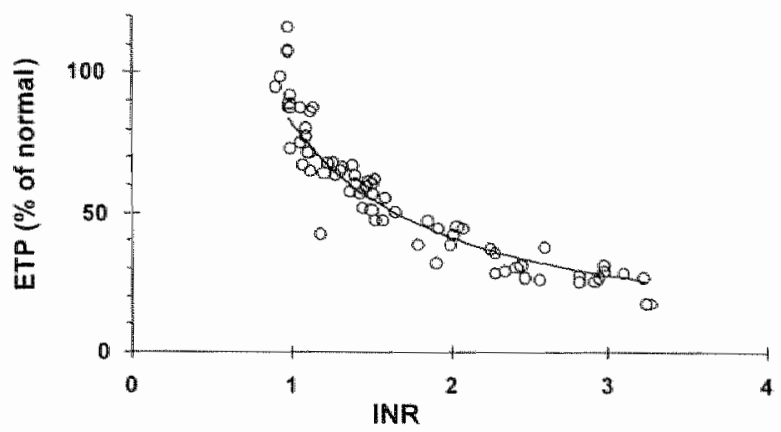

Figure 5.1. WNA and ETP in treatment with oral anticoagulants (Figure by courtesy of H.C. Hemker, dep. of Biochemistry, University of Maastricht, The Netherlands).

proof that aspirin acts on thrombin generation in PPP is still lacking. We did not determine individual clotting factors in our patients. In the volunteers, where we did determine individual clotting factors, no effect of aspirin on thrombin generation in PPP was observed.

The effect of aspirin in PRP is probably related to a decrease in platelet procoagulant activily. Effects of aspirin in the presence of platelets have been observed before. ${ }^{152} 19192$ The mechanism by which aspirin inhibits the platelet contribution to thrombin generation remains unknown. It seems likely that inhibition of platelet-derived tromboxane lormation is the principal anthrombotic mechanism of aspirin. However, tromboxane induced platelel activation is not involved in the exposure of platelet procoagulant phospholipids. 9.98 nor in thrombin induced platelet activation, ${ }^{166}$ that occurs under our experimental circumstances. Thus, inhibition of the cyclooxygenase pathway might explain a prolongation of the lag phase. ${ }^{19}$ but not of the reduced amount of thrombin formed. that have been suggested are speculative and sometimes unlikely (acetylation of prothrombin of of GTP-binding proteins, interaction with platelet membrane phospholipids ${ }^{192}$ ). It remains interesting to see that the aspirin effect is particularly obvious in those patients in which the thrombin generation in PRP is elevated. The mechanism by which this elevation is intuenced is not elucidaled, and further studies are required. 
The decrease in thrombin generation (about 10\%) that we observed with $30 \mathrm{mg}$ of aspirin daly in our controls and in subgroups of patients is similar to those 1 hour atter intake of $1 \mathrm{~g}$ of aspirin: which shows that this aspirm effect is dose-independent and limited. This raises the interesting question of how much the ETP has to decrease to obtain adequate prophylaxis.

\section{Oral anticoagulation}

In the healthy volunteers we found a decrease in ETP in the extrinsic coagulation system of about $3 \%$. The decrease in the intrinsic ETP was not statistically significant. Fixed low-dose anticoagulants reduced ETP in PRP with $11 \%$ only in the subgroup of patients with platelet related hypercoagulabilty. Because in this subgroup the same decrease in ETP (10\%) was observed after aspirin use, fixed low-dose oral anticoagulants do not seem to have a additional eflect over aspirin. Moreover, platelet derived procoagulant activity only decreased with aspirin, suggesting that aspirin could even be more effective than phenprocoumon.

'Mini-intensity' anticoagulation with wartarin has been reported to affect hypercoagulation markers, specifically $\mathbb{F}_{1+2}$ levels. ${ }^{13} 58$ ige Fixed low-dose oral anticoagulants were effective in reducing the incidence of deep vein thrombosis after major gynaecological surgery ${ }^{12}{ }^{13}$ and in the prevention of thrombotic events in cancer patients, ${ }^{200}$ but the combination of aspirin and fixed low-dose warfarin had no additional effect over aspirin alone in paltients

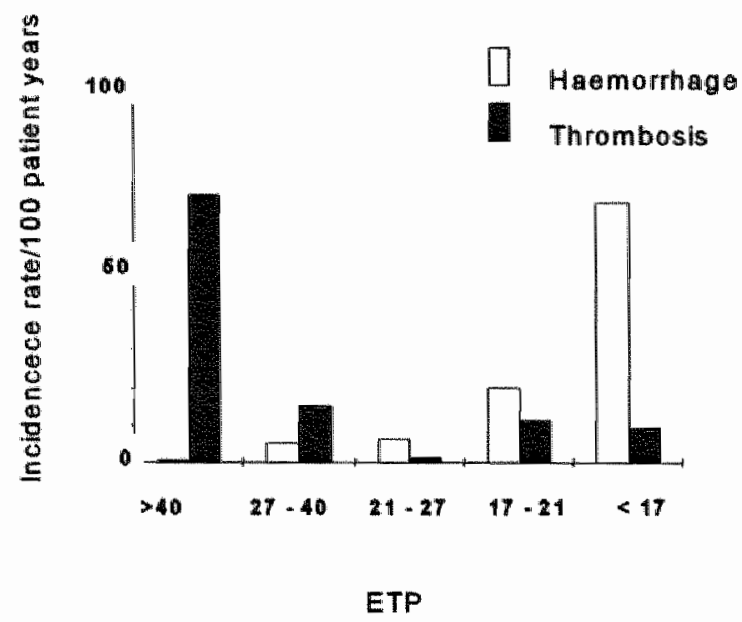

Figure 5.2. Thrombotic and hamarthagic events during treabment with oral anticoaguiants, as function of the percentage of the ETP ffigure modified Irom Azar. ${ }^{202}$ by courtesy of the author). 
atter myocardial infarction, ${ }^{\dagger 5}$ Low-intensity wartarin (INR below 2 o) had no effect in the prevention of stroke in patients with non-rhetnatic atrial fibrillation. 189190 This concurs with our findings, that provide no laboratory support for an important effect of fixed low-dose oral anticoagulans, neither in our young stroke patients, nor in healthy controls.

Neither in the controls nor in the young stroke patients did the use of fixed low-dose phenprocoumon influence the prothrombin-lime expressed in INR. This finding is in accordance with a previous study, where INR did not change after six weeks of fixed low-dose wartarin, but only after adjusted dose warfarin. 200

The effect of phenprocoumon in PPP is, on the whole, reflected in PRP, but not quantitatively. Theoretically, the two do not have to be identical. Apart from the procoagulant factors $11, V I I, I X$ and $X$, also the down-regulators protein $C$ and proten $S$ are vitamin $K$ dependant. The equilibrim between pro- and anticoagulant effects is determined by the types of phospholipids available ${ }^{201}$ In PPP phospholipids are added, but in PRP they are provided by the platelets, so the quantitative effects of anticoagulation need not be identical.

The minimal effect on thrombin generation obtained by $0.75 \mathrm{mg}$ phemprocoumon per day raises two questions:

1. What is the minima! anticoagulant effect that might give sate protection against thromboembolic events in young stroke patients?

2. How could this effect be obtained and is there a need for laboralory control?

Ad 1. The risk of myocardial reinfarction as a function of the INR are known from previous studies. 202209 We determined the relation between INP and ETP (fig. 5.1) and moditied the data of Azar in lerms of inhibition of the ETP (fig. 5.2). This allows us to conclude that $60 \%$ inhibition of the ETP suffices lo reduce the risk of myocardial infarction, whereas bleeding complicalions increase if the inhibition exceeds $80 \%$. Unluckily, cerebral blecding in the ciseased brain occurs more readily than bleeding in general."

If the eficacy of aspirin would be due to the decrease of the ETP in PRP. than $10 \%$ decrease of the ETP in PRP has a moderate bul definite elleo in the secondary prewention of thromboembolic events, and it would be a reasonable guess to aim at the range of $20-40 \%$ of intibition of the ETP as the window for secondary prevention of cerebral intarction.

Ad 2. From figure 5.1 it can be seen that $20-40 \%$ inhibition of the ETP corresponds to a range of INR beween $1 . " 1$ and 1.4 . It is also evident from the hyperbolic relationship beween INR and ETP that the INR is extremely insensitive in this range, and hence unsultable as a means of laboralory control.

The question how to reach a $20-40 \%$ of inhibition of the EIP with a fixed dose of a vitamin $K$ antagonist can not be answered at this moment. From the 
data available at the Maastricht Thrombosis Serwice we know that a stable anticoagulation at an INR $2.5-4.2$ (inhibition of ETP $60-70 \%$ ), requires $3 \pm 0.6$ $\mathrm{mg}$ of phenprocoumon. This means that with a standard dose of $3 \mathrm{mg}$ phenprocoumon $15 \%$ of a population would be anticoagulated at a $<60 \%$ level and $15 \%$ at a $>70 \%$ level. This suggests that the variation in interindividual responses is too large to obtain stable anticoagulation in the relatively narrow range of $20-40 \%$ inhibition with a fixed dose of phenprocoumon.

The effect of aspirin in the secondary prevention of stroke is clinically significant, but still moderate. Antiplatelet therapy results in an absolute risk reduction in non-fatal stroke of $2 \%(8.2 \%$ in treated patients, $10.2 \%$ in controls) in patients with a prior stroke or transient ischaemic attack (TIA). ${ }^{104}$ This clearly suggests the need for more effective antithrombotic therapy. In our young stroke patients with platelet related hypercoagulability both aspirin and fixed low-dose phenprocoumon resulted in a significant reduction of $10 \%$ of ETP in PRP, but the values of ETP still remained elevated. In the other patient subgroups there was no significant influence of aspirin on phenprocoumon on ETP in PRP. Maybe in subgroups of palients other (antiplatelet) therapy would be more beneficial. In the search for those drugs the ETP could be a useful screening lest to study the effect of medication on thrombin generation.

In conclusion: Aspirin modulated the thypercoagulable state as measured by the ETP in young stroke patients, especially in those patients with platelel related hypercoagulability. The effect on decreasing thrombin generation however, is only mild. There is no laboratory support for a more beneficial effect of fixed low-dose phenprocoumon compared to aspirin. 
Chapter

General discussion 
When a young person develops an ischaemic stroke withoul a definie cause despile extensive investigations, it means that current knowledge is insufficient to identify the cause of that stroke. In up to $50 \%$ of young stroke patients no definite cause can be found. " 1 taz Many disorders in various paihophysiological domains may contribute to the cause of the stroke, among which are rheologic or haemostatic abnomalities. These abnomalites may play a more impontant role in some ischaemic stroke subtypes than in others. e.g. a definite stroke cause is less often identified in lacunar than in terilorial ischaemic stroke. ${ }^{23}$ With the experments described in this thesis we aimed to contribute to the understanding of pathogenetic mechanisms involving haemostatic function in young patients suffering ischaemic stroke Knowledge of such mechanisms could foster a rational approach towards the prevention of recurrent vascular events in these patients.

Enhanced red blood cell aggregation can increase blood viscosity and in this way diminishes blood flow. ${ }^{78} .70-72$ Several studies lound enhanced red blood cell aggregation to be related to ischaemic stroke. Some ascribed such correlation to an increased fibrinogen level. However, we found an enhanced red blood cell aggregation in young stroke patients not related to the librinogen level. Therefore, our findings indicate that some other factor, maybe some plasma prokein other than fibrinogen, is responsible for the increased aggregability of red blood cells in these patients. Another possible explanation is that enhanced red blood cell aggregation is secondary to platelet activation, ${ }^{7}$ because thrombospondin, one of the contents of the platelet $\alpha$-granules, may induce enythrocyte aggregation, ${ }^{81}$ whereas eryllnocyle aggregation in turn can increase platelet procoagulan responses. Under certain conditions erythrocytes can develop procoagulant aclivily by a transbliayer movement of procoagulant phosphollpids, ${ }^{\text {ex }}$ thereby influencing the haemostatic functions of the blood. Erythrocyles can enhance platelet activily. ${ }^{79}$ whereas enhanced red blood cell aggregation can exacerbate platelet aggregation. Further sludy on erythrocyle platelet interactions may eventualy allow a better understanding of the role of enhanced erythrocyte aggregation in the pathogenesis of ischaemic stroke This will be a point of future interest.

The coagulation mechanism in plasma inat is responsible for the generation and subsequent inhibition of thrombin in clotting blood may lead to a thrombotic tendency when producing too much free thrombin (hypercoagulability). The ability to detect coagulation abnormalities as a possible contributor to the development of stroke depends on the availability of a sensitive test of the coagulation system. Global clotting assays are often used 10 detect hypercoagulability. However, the clotting time represents only the $10 \mathrm{mM}$ thombin required to convert fibrinogen into fibrin, whereas 
thrombin generation continues untit a peak of about $200 \mathrm{nM}$ is reached. Therefore, clotting times are much more sensitive to hypocoagulability than to hypercoagulability. The time integral of thrombin formation, i.e. the endogenous thrombin potential (ETP), is an overall indicator of the plasma coagulability, and can be used as a screening parameter of the coagulation system. Measurement of the ETP in platelet rich and in platelet poor plasma allows detemination of hypercoagulability. whereas it also differentiates between abnormalities in the plasmatic and the cellular coagullation system. The possibility to separately identify patients with hypercoagulability either due to the plasmatic coagulation system or related to platelets may eventualy allow a more rational therapeutic approach. We found a plasma based typercoagulability in about one third of our young stroke patients, whereas in about a quarter of these patients a platelet related hypercoagulability could be identified. A high thrombin generation in platelet rich plasma possibly may increase the risk of stroke, whereas plasma based hypercoagulabilily may increase the risk of recurrent stroke. These findings indicate that the role of hypercoagulability in the development of cryptogenic stroke in the young may be far more important than so far assumed. 2425 What specific coagulation abnormalities cause this hypercoagulability is not yet known, but our findings may direct towards further exploration of underlying causes. The ETP can thereby be helpful in identifying the type of hypercoagulability (plasma besed or due to platelets). Moreover, with the ETP we were able to exclude hypercoagulability in about $50 \%$ of our patients. Theretore, using the ETP may limit the need for further extensive (and often expensive) laboratory investigations for specitic coagulation abnormalities in these patients.

Measurement of thrombin formation in platelet rich plasma is valuable because it includes the influence of the blood platelets, which in vivo provide the phospholipid surface necessary for the prothrombinase anchorage. Theretore, the ETP in platelet rich plasma represents the siluation in wo better than thrombin generation in platelet poor plasma. However, other blood cells, the vessel wall, and flow characteristics which are present in wivo. do not play a role in the thrombin generation test. Nevertheless, the ETP in platelet rich plasma reveals hypercoagulability in young stroke patients that is not detected by other lests. In its present form however, it is nol an easy lest that can be applied on a routine basis. One test requires wo working hours by experienced technicians. Therefore, it would be very advantageous 10 develop an automatised procedure for the thrombingeneration lest in platelet rich plasma. This already exists for the measurement of thrombin formation in platelet poor plasma.

We demonstrated a high platelet procoagulant activity and an clevated WF in young stroke patients, and both were related to thrombin generation in platelet rich plasma. WWF is one of the necessary mediators in the mechanism that brings out platelet procoagulant activity in platelets. Thrombin induces 
platelet procoagulant activity in a GPIb/lla dependent process. Fibrin requires GPlb for making the platelets procoagulant. WWF is a necessary colactor in both mechanisms." 104 Activated platelets provide the procoagulant surface needed for the activation of factor $X$ and prothrombin." whe moment on which the platelets massively expose their procoagulant surface and shed procoagulant microvesicles, thrombin will massively be generated. Thrombin in tum, is one of the most potent platelet activators. The generation of thrombin and the development of platelet procoagulant activity are thus clasely linked, which also can be deduced from the correlation between ETP and platelet procoagulant activity in our patients. The cevelopment of platelel procoagulant achivly, as indicated above, is in more than one way dependent on WWF. We found an elevated concentration of vWF in young stroke patients, which was related to thrombin generation and platelet procoagulant activity. Obviously, WWF is not merey a marker of endotheliat damage, but plays an essential role in coagulation through its effect on platlelel activation. Our findings therefore provide a pathophysiological explanation for the epidemiological observation that relates an increased concentration of WWF the occurrence of stroke and to the increased mortality in stroke survivors. ${ }^{9}$ Moreover. WV could play a crucial role in the induction of a prethrombotic state in a subgroup of young stroke patients. Therelore, inhibition of WWF platelet receptors, like GPIlb/lla or GPlb, can influence the interaction of WF with platelet activation and subsequent thrombin generation. Thrombin generation decreased atter addition of GPllb/lla antagonists, indicating that GPllb/lla has a function in the platelet procoagulant response 204

In elderly stroke patients atherosclerosis is the mosl frequent cause of stroke. Coagulation enzyme activity increases with age, ${ }^{05}$ and might be the basis of a thrombotic tendency. Theretore, a prethrombotic stale may contribute to the development of stroke in elderly patients as well. A coexistent atheroscierosis could obscure the role of such a coagulopathy, but may on the other hand induce hypercoagulability. By using the ETP as a screening parameter for the coagulation system, the role al coagulation abmormalities in elderly stroke patients may be elucidated. Moreover, since stroke incidence in elderly patients is much higher, in such a study attention. could be given to distinguish between stroke sublypes. Since the pathogenesis of lacunar and territorial infarcts is different, ${ }^{35} 200$ it could be possible that there are difierences in the prevalence of hypercoagulability belween stroke subtypes. We were not able to demonstrate differences beween lacunar and terntorial stroke due to the small numbers in the different stroke subgroups. Insight into pathophysiological mechamisms of stroke sublypes may have important consequences for tailored therapeutical decisions. Recently, this was demonstrated by the excess of fatal bleedings in TIA or minor stroke patients with white matter lesions during oral 
anticoagulant therapy," indicating that consequences of antithombotic therapy are different in different subsets of stroke patients.

Secondary prevention is an important aspect in stroke management. Up till now, most patients with stroke or TIA of presumed arterial origin are lreated with antiplatelet therapy. This results in an absolute risk reduction in non-fatal stroke of $2 \%$ ( $8.2 \%$ in ireated patients, $10.2 \%$ in controls). ${ }^{10}$ Therelore, there is a need for a more potent modality, with a low risk of bleeding complications. Theoretically, patients with presumed platelet induced hypercoagulability would benefit from antiplatelet therapy, whereas any effect of fixed low-dose oral anticoagulants is more likely in patients with hypercoagulability due to the plasmatic coagulation system. A more rational prescription of a preventive drug requires recagnition and classification of plasma or platelet besed hypercoagulability. The ETP is sensitive screening parameter for the coagulation system and is known to be decreased by heparin, standard dose oral anticoagulants, and antiplatelet drugs (aspirin. GPllb/lla blockers). The ETP allows identification of patient subgroups in which antiplatelet drugs, oral anticoagulants, or other newly developed drugs could be more rationally tested, instead of lumping all stroke patients together in therapeutic experiments. Furthermore, in the future the ETP might be useful as a screening test in (trials on) primary prevention to identify patients at high risk for thromboembolic events. ${ }^{207-200}$

Among the healthy volunteers who used aspirin we found a decrease in thrombin generation in platelet rich plasma of about $8 \%$, while in young stroke patients thrombin gleneration in platelet rich plasma decreased by $10 \%$, but only in the subgroup with platelet based hypercoagulability. Other authors also observed a decrease in thrombin generation by about $10 \%$, possibly through its effect on the production of procoagulant phosphotipids. 152102 Indeed, platelet procoagulant activity in our young stroke patients decreased significantly after aspirin use, but not in the comtrols. Furthermore, aspirin also decreased the extrinsic ETP in the patient subgroup with plasma based hypercoagulability. Inhibition of platelet-derived tromboxane formation is the principal recognized antithrombotic mechanism of aspirin. However, also tromboxane-independent actions of aspirin might be inwolved in ils antithrombotic effect, and underie its influence on thrombin generation. Aspinin can influence the plasma lewels of the vilamin K-dependent coagulation factors, though this effect was only seen at high dosages 100 $\mathrm{mg} / \mathrm{kg}$ by intraperitoneal injection; $1 \mathrm{~g} / \mathrm{kg}$ by a single intramuscularly injection). ${ }^{193: 97}$ Apart trom the dose, also duration of aspirin treatment could influence coagulation lactors. Theretore, a decrease in thombin generation might also have been induced by long-lem low.dose aspint treatment in our patients. 
Low-dose aspirin treatment in our study decreased thrombin generalion only in those patients with an elevated ETP. This finding could mean that in the secondary prevention of stroke some patients may require high-dose aspirin, a different antiplatelel drug, ${ }^{210}$ or a combination of drugs, such as aspirin with dipyridamole, as recently found in the ESPS2." Fixed low-dose phenprocoumon did not reduce thrombin generation more than aspirin did. The dose of phenprocoumon in our study population was $0,75 \mathrm{mg}$ a day. Maybe a higher dose would have been more effective. At a higher dose. however, laboratory monitoring would be necessary, because there are patients who will become fully anticoagulated with $1.5 \mathrm{mg} / \mathrm{day}$ phenprocoumon. Low-dose oral anticoagulants were proven efficacious in the prevention of thrombotic complications in some studies in patients after major surgery. ${ }^{12} 13$ Low-dose oral anticoagulants may be effective in some patients, but not in all and in our opinion some laboratory control will aways be required.

Since the ETP is universally inhibited by all antithombotics, no matter what the antithrombotic mechanism is, it is very sensitive for the evaluation of the potential therapeutic effect of any therapeutic modality. It offers an attractive opportunity to evaluate the effect of drug treatment on thrombin glemeration, before starting a large randomized trall without difierentiating what patients may and what patients likely will not benefit. Restricted entry of patients with a high probability of therapeutic effect would make any clinical trial on antithrombotics in many aspecis much more feasible.

Various antithrombotic drugs are currenty being evaluated. Thienopyridines, such as ticlopidine or clopidogrel, are valuable alternatives if platelet activation results from shear stress or ADP. Clopidogrel has been proven effective in reducing vascular events. though the absolute risk reduction compared to aspirin was only $0.5 \%{ }^{210212}$ GPllbilla antagonists are considerably more potent than aspirin in acule vessel obstructions, ${ }^{213} 214$ but also have a substantially higher risk of bleeding. ${ }^{192} 215216$ itt seems likely that the best target for new antithrombotic arugs is the inhibition of thrombin generation. To coin such drugs the ETP may be the screening procedure of choice. Therefore, making the ETP in platelet rich plasma available for routine use would be most welcome and could facilitate further basic as well as climical research. 
Chapter

Summary 
Etfective prevention of stroke is best applied on basis of the pathophysiological mechanism underlying the stroke. In many young stroke patients however, this mechanism remains uncertain. Conflicting data exist about hypercoagulability as a possible contributor to ischaemic stroke in young patients. Extensive laboratory screening for prethrombotic slates in stroke patients is limited to the recognition of a number of kmown diseases. that cause hypercoagulability, such as the tactor $V$ Leiden mutation. deficiencies of proteins $C$ and $S$, hyperhomocysteinaernia elc. Such screening is expensive and not widely available. Besides, it often provides only negative information, because only specific, known causes of hypercoagulability can be imvestigated. Instead of investigating a large number of possible causes of hypercoagulability, it would be a great advanlage 10 have a screening parameter of the coagulation system as a whole, i.e. the plasmatic coagulation system logether with the platelets. In this way further specific testing could be limited to patients with an identified hypercoagulability. It was the main aim of this thesis to investigate whether an overall test, the endogenous thrombin potential (ETP), can be used as such a screening parameter in young stroke patients. With the ETP. measured both in platelet rich plasma and in platelet poor plasma, it is possible to differentiate between nypercoagulability due to platelets, or hypercoagulability due to the plasmatic coagulation system. Also the influence of medication on the hypercoagulability can be studied with the ETP. Apart from cardioembolic stroke, secondary stroke prevention up till now is limited to antiplatelet therapy, which is only moderately eflective. In specific subgroups other medication, like fixed low-dose oral anticoagulants. may be more effective in preventing vascular events. With the use of the ETP it may be possible to stratily young stroke patients in groups that will benefit from either oral anticoagulant or antiplatelet therapy.

In Chapter 2 we set out to explore the role of erythrocyte aggregation in young palients with non-cardioembolic stroke. Enhanced red blood cell aggregation is considered as a factor related to the pathogenesis of stroke in elderly patients, in whom enhanced red blood cell aggregation is correlated with increased fibrinogen. In young stroke patients we found an enhanced red blood cell aggregation compared to young controls, both in the early and in the late phases, whereas fibrinogen was normal. Red blood cell aggregation was significantly associated with stroke after adjusting for diflerences in fibrinogen, hematocrit and erythrocyte sedimentation rate. Ped blood cell aggregation was higher in elderly patients than in elderly controls. In elderly patients increased fibrinogen was associated with stroke. We concluded that enhanced red blood cell aggregation independently relates to stroke in young people, which may suggest that enhanced red blood cell 
aggregation contributes to stroke cause. whereas in eldery patients any such effect is probably explained by confounding by raised fibrinogen.

In Chapter 3 we determined whether young stroke patients have abnormalities in the plasmatic coagulation system. Furthermore, to investigate whet ther there were any disturbances in the protein $C$ pathway, we added an activator of protein $\mathrm{C}$, thrombomodulin, to the thrombin generation assay. With the use of the ETP in platelet poor plasma as a screening parameter of the plasmatic coagulation system, we found a plasma based hypercoagulability in about one third of young stroke patients. Patients with recurrent stroke had a significantly higher ETP than those without. After the addition of thrombomodulin five patients had an insufficient inhibition of thrombin generation, indicating an abnomality in the protein $\mathrm{C}$ pathway. Abnormalities in the protein $\mathrm{C}$ pathway are easily detectable with the thrombomodulin test, and may contribute to the development of stroke in the presence of other vascular risk lactors. In patients with an idenified hyperactive coagulation system, further investigations into the cause of this plasma based thrombotic tendency are warranted.

In Chapter 4 we tested whether young stroke patients have a hypercoagulability related to the blood platelets. Comparing the ETP in platelet rich plasma to the ETP in platelet poor plasma allows distinction between platelet related or plasma based hypercoagulability. The won Willebrand factor is a necessary mediator in the mechanism that brings out procoagulant activity in plateles. Therefore, we also determined platelet procaagulant activity and the concentration of von Willebrand factor. The ETP in platelet rich plasma was significantly higher in young stroke patients than in controls. Platelet procoagulant activity and von Willebrand lactor were also significantly higher in patients than in controls. High ETP was significantly associated with stroke. In a linear regression model von Willebrand lactor concentration was associated with platelet procoagulant activily and with the ETP. whereas platelet procoagulant activity also was associated with the ETP. We concluded that thrombin generation in platelet rich plasma is elevaled in young stroke patients. Both platelet derived procoagulant activily and von Willebrand factor are increased in young stroke patients and are related to the ETP in platelet rich plasma. This indicates that among the numerous causes that may be behind an increased ETP. a high concentration of won Willebrand factor is of significant importance. Our findings provide a pathophysiological explanation for the epidemiological observation that relates increased concentration of von Willebrand lactor to the occurrence of stroke. 
In Chapter 5 we investigated the influence of aspirin and of fixed low-dose oral anticoagulants on thrombin generation in healthy volunteers and in young stroke patients. It would be advantageous if patients with hypercoagulability. either due to the plasmatic coagulation system or related to platelets, could be separately identified, as this may eventually allow a more rational prescription of a preventive drug. It is conceivable that a decrease in the thrombin generation, induced by aspirin or fixed low-dose oral anticoagulants, lowers the risk of thrombotic events in patients. In the controls there was a mild but significant decrease (ca. $8 \%$ ) of the ETP in platelet rich plasma after two weeks of aspirin intake ( $30 \mathrm{mg} /$ day), whereas in the patienis such an effect was seen only in the subgroup with platelet related hypercoagulability. In the patients with plasma based hypercoagulability the ETP in the extrinsic pathway decreased after aspirin use. Platelei procoagulant activity decreased in our young stroke patients after aspirin treatment. Fixed low-dose phenprocoumon $(0,75 \mathrm{mg} / \mathrm{day})$ in the controls decreased only the extrinsic ETP in platelet poor plasma, which effect was also seen in the patients. Also in the patient subgroup with platelet related hypercoagulability thrombin generation in platelet rich plasma decreased after phenprocoumon. We concluded that aspirin modulated the hypercoagulable state as measured by the ETP in young stroke patients. especially in those patients with platelet related hypercoagulability. However. it has only a mild effect on decreasing thrombin generation. We found no laboratory support for a potential higher effectiveness of fixed low-dose phenprocoumon compared to aspirin on the prevention of thromboembolic events.

In Chapter 6 we discussed the results of our studies on enhanced erythrocyte aggregation and on hypercoagulability in young stroke patients, in relationship with current and potential future therapeutical options for secondary stroke prevention. We recommend further study on ETP detectable hypercoagulability in elderly stroke patients and in patient subgroups. The availability of a routinely usable ETP measurement in platelet rich plasma would be of great advantage to such further studies. It would also offer an attractive opportunity to tailor future therapeutic modalities to subgroups of patients, identified with the ETP. 


\section{Chapter}

Samenvatting 
Preventie van het herseninfarct is het meest effectief indien dit gericht kan worden op de onderliggende oarzaak van dit herseninfarct. Bij veel jonge patiënten met een herseninfarct wordt, ondanks uitgebreid aanvullend onderzoek, echter geen duidelijke oorzaak aangetoond. In de literatuur worden verschillende getallen genoemd omtrent hypercoagulabiliteil als mogelijke factor die bijdraagt aan het ontstaan van een herseninfarct op jonge leeftijd. Uitgebreid laboratorium onderzoek naar een zogenaamde 'prethrombotic state' bij deze patiënten is beperkt tot de herkenning van een aantal bekende aandoeningen die hypercoagulabiliteit veroorzaken, zoals factor $V$ Leiden mutatie, deficientie van proteine $C$ of $S$, hyperhomocysteinemie, enz. Dergelijk screenend onderzoek is duur, en niet overal uitvoerbaar. Daarnaast levert dit vaak slechts negatieve resultaten op, omdat alieen specificke, al bekende oorzaken van hypercoagulabiliteit kunnen worden onderzocht. Het zou een groot voordeel zijn als men zou beschikken over een screeningsparameter voor het totale stollingsysteem (dus hel plasmatisch stollingsysteem samen met de bloedplaatjes). Dit zou als voordeel hebben dat verder onderzoek naar stollingsafwijkingen beperkt zou kunnen worden tol die patiënten met een geidentificeerde hypercoagulabiliteit. Het voornaamste doel van dit proefschrift was dan ook om te onderzoeken of zo'n test gebruikt kan worden als een dergelijke screeningsparameter bij jonge patiënten met een herseninfarct. De 'endogene trombine potentiaal' (ETP) is een dergelijke test. waarmee een totale indruk kan worden verkregen over het stollingssysteem. Met behulp van de ETP, gemeten in plaatjesrijk en in plaatjesarm plasma, is thet bovendien mogelijk onderscheid te maken tussen hypercoagulabiliteit ten gevolge van de bloedplaatjes, en hypercoagullabilitieit ten gevolge van hel plasmatisch stollingsysteem. Ook kan het effect van medicatie op de hypercoagulabiliteit mel behulp van de ETP worden bestudeerd. Mel uitzondering van het herseninfarct ten gevolge van een cardiale embolie, is de secundaire preventie van het ischemisch CVA tot op heden beperkt tot plaatjes-aggregatie remmers; een therapie die slechts een beperkte effectiviteil heeft. In specifieke subgroepen zou andere medicalie, zoals bijvoorbeeld een vaste, lage dosis orale anticoagulantia, wellicht meer effectiel zijn. Met behulp van de ETP is het mogelijk bepaalde subgroepen patiënten te onderscheiden, die wellicht meer baat hebben bij orale anticoagullantia, danwel aspirine.

In Hoofdstuk 2 is de rol onderzocht van aggregatie van rade bloedcellen bil jonge patiènten met een herseninfarct. Een verhoogde erytrocyten aggregatie wordt beschouwd als een factor die gerelateerd is aan de pathogenese van het herseninfarct bij oudere patienten. Bij deze patiënten is de verhoogde erytrocyten aggregatie gecorreleerd aan een verhoogd fibrinogeen. Bij jonge patiënten met een herseninfarct vonden wij een 
verhoogde erytrocyten aggregatie vergeleken met controlepersonen, zowel in de acute als in de late fase na het infarct, terwill de fibrinogeen concentratie normaal was. Erytrocyten aggregatie was significant geassocieerd met het herseninfarct na correctie voor verschillen in fibrinogeen, hematocriet en bezinking. Ook bij de oudere patiënten was de erytrocyten aggregatie verhoogd, vergeleken met oudere controlepersonen. Bij deze oudere patiënten bleek een verhoogd fibrinogeen geassocieerd te zijn met het optreden van een herseninfarct. Wij concludeerden dat een verhoogde erytrocyten aggregatie onafhankelijk gerelateerd is aan het optreden van een herseninfarct op jonge leeftijd, hetgeen erop zou kunnen wijzen dal een verhoogde erytrocyten aggregatie bijdraagt aan de oorzaak van dit herseninfarct. Bij oudere patiënten lijkt een verhoogde erytrocyten aggregatie voornamelijk te worden veroorzaakt door een verhoogd fibrinogeen.

In Hoofdstuk 3 bepaalden we in hoeverre jonge patiënten met een herseninfarct afwijkingen hebben in het plasmatisch stollingssysteem. Daarnaast onderzochten wij ook of er afwijkingen bestonden in de 'protein $\mathrm{C}$ pathway', door een activator van proteine $C$ (thrombomoduline) toe te voegen aan de trombine generatie test. Met behulp van de ETP in plaatjesarm plasma, vonden we een plasma-gebonden hypercoagulabiliteit bij ongeveer één derde van de jonge patiënten met een herseninfarct. Patiënten die een recidief herseninfarct hadden doorgemaakt, bleken een significant hogere ETP te hebben dan de overige patiënten. Na toevoegen van thrombomoduline hadden vijf patiënten onvoldoende remming van de trombine generatie, hetgeen wijst op een onvoldaende functie van de 'protein $\mathrm{C}$ pathway'. Afwijkingen in de protein $\mathrm{C}$ pathway zijn gemakkelijk op te sporen met de thrombomoduline test, en kunnen bijdragen aan het ontstaan van een herseninfarct, vooral indien er ook nog andere vasculaire risicotactoren aanwezig zijn. Bij patiënten mel een aangetoonde afwijking in het plasmatisch stollingsysteem is verder onderzoek naar de oonzaak van deze hypercoagulabiliteit aangewezen.

In Hootdstuk 4 onderzochten we of jonge patiënten met een herseninlarcl hypercoagulabiliteit hebben, gerelateerd aan de bloedplaaijes. Door de ETP in plaajiesrijk plasma te vergelijken met de ETP in plaatjesarm plasma, kan onderscheid worden gemaakt tussen hypercoagulabiliteil op basis van hel plasmatisch stollingssysteem, danvel de bloedplaatjes. De von Willebrand factor is een noodzakelijke mediator bij het mechanisme dat procoagulante activiteit in plaatjes teweeg brengt. Daarom onderzochten we ook de plaaljes procoagulante activiteit en de von Willebrand tactor concentratie. De ETP in plaatjesrijk plasma was significant hoger bij de patiënten in vergelijking met controlepersonen. Ook de plaatjes procoagulante activiteit en de von Willebrand factor waren significant hoger in patiënten dan in de controles. 
Een hoge ETP was significant geassocieerd met een herseninfarct. In een lineair regressiemodel was de von Willebrand factor geassocieerd met de plaaljes procoagulante activiteit en met de ETP, lerwill de plaatles procoagulante activiteit ook geassocieerd was met de ETP. Wij concludeerden dat de trombine generatie is verhoogd bil jonge patienten met een herseninfarct. Zowel de plaaties procoagulante activiteit als de won Willebrand lactor zin verhoogd bij jonge patienten met een hersenmtarct, en zij zijn gerelateerd aan de ETP in plaatiesrijk plasma. Dit wijst erop dat onder de verschillende corzaken die ten grondslag kunnen liggen aan een verhoogde ETP, een hoge concentratie van de von Willebrand faclor een belangrike rol speelt. Deze bevindingen geven een pathofysiologische verklaring woor de epidemiologische observatie dat een verhoogde von Willebrand factor concentratie is gerelateend aan het optreden van een hersemintarcl.

In Hooldstuk 5 hebben we de invloed van aspirine en van een vaste. lage dosering orale anticoagulantia op de trombine generatie onderzocht, zowel bij jonge patienten met een herseninfarct als bij gezonde vrijwilligers. Het is aannemelijk dat een vermindering van de trombine generatie, door behandeling met aspirine of orale anticoagulantia, samengaat mel een vermindering van het risico op een trombo-mbolische gebeurtenis bif patiënten. Bij de controlepersonen bestond een verlaging van de ETP (ca. $8 \%$ ) in plaaljesrijk plasma na aspirine gebruik (30 mg/dag) gedurende twee weken, terwijl bij de patiënten een dergelijk effect alleen werd gezien bij de subgroep mel plaatjes-gerelateerde hypercoagulabiliteit. Bij patiënten mel een plasma-gebaseerde hypercoagulabiliteit daalde de extrinsieke ETP tijdens aspirine gebruik. De plaatjes procoagulante activiteit daalde bij onze patienten tijdens het gebruik van aspirine. Een vaste, lage dosering phenprocoumon $(0,75 \mathrm{mg} / \mathrm{dag})$ bij de controlepersonen veminderde alleen de extrinsieke ETP. Hetzelfde eftect werd bij de patiënten gezien. Bij de subgroep palienten mel een plaatjes-gerelateerde hypercoagulabiliteil daalde ook de ETP in plaatjesrijk plasma na gebruik van phenprocoumon. We concludeerden dat aspirine de hypercoagulabiliteil, gemeten met behulp van de ETP, bij jonge patienten met een hersenintarct beinvloedt, speciaal in die groep met een plaatjes-gerelateerde hypercoagulabiliteit. Het effect op de trombine generalle is echter slechts mild. Wij wonden geen laboratorium ondersteuning voor het idee dat een vaste, lage dosering phenprocoumon effectiever is dan aspirine bij de preventie van tromboembolische gebeurtenissen.

In Hoof stuk 6 hebben we de resultaten van ons onderzoek naar een verhoogde erytrocyten aggregatie en naar hypercoagulabilitieit bij jonge patienten met een herseninfarct besproken. Ook bediscussieerden we onze 
bevindingen in relatie tot huidige en toekomstige therapeutische opties voor de secundaire preventie van het herseninfarct. Wij adviseren verder onderzoek naar hypercoagulabiliteit, onderzocht met behulp van de ETP. bij oudere patiënten en bij subgroepen patiënten. Het beschikbaar zijn van een geautomatiseerde versie van de ETP in plaatjesrijk plasma zou bij dergelijk studies van groot nut zijn. Dit zou ook de mogelijkheid bieden om toekomstige therapeutische alternatieven te richten op subgroepen van patiënten, die met behulp van de ETP te onderscheiden zijn. 



\section{References}

1. Bonita R. Epidemiology of stroke. Lancet 1992;339:342-344

2. Bogousslavsky J. Pierre P. Ischemic stroke in patients under age 45 . Neurol Clin 1992:10:113-124.

3. Awada A. Stroke in Saudi Arabian young adults: a study of 120 cases. Acta Neuro Scand 1994,89:323-328

4. Qureshi Al, Saldar K, Patel M. Janssen RS, Frankel MR. Stroke in young black patients: Risk lactors, sublypes, and prognosis. Stroke 1995:26:19951998.

5. Hart RG, Kanter MC. Hematologic disorders and ischemic stroke. A selective review. Stroke 1990;21:1111-1121.

6. Tanahashi N, Gotoh F, Tomita M, Shinohara T, Terayama Y, Mihara B, et al Enhanced erythrocyte aggregability in occlusive cerebrovascular disease Stroke 1989:20:1202-1207.

7. Beguin $S_{1}$ Kumar $R$. Thrombin, tibrin and platelets: A resonance loop in which von Willebrand factor is a necessary link. Thromb thaemost 1997; 78:590-594.

8. Qizilbash N, Dutty S, Prentice CRM, Boothby M. Wartow C. Von Willebrand factor and risk of ischemic stroke. Neurology 1997:49:1552-1556

9. Catlo AJ, Carter AM, Barrett JH, Bamtord J, Fice PJ, Grant PJ. von Willebrand factor and factor VIll: $C$ in acute cerebrovascular disease Felationship to stroke subtype and mortalily. Thromb Haemos: 1997:77:1104 1108.

10. Collaborative overview of randomised trials of antiplatelet therapy-l: Prevention of cleath, myocardial infarction, and stroke by prolonged antiplatelet therapy in various categories of patients. Antiplatelet Trialists" Collaboration. BMJ 1994,308:81-106

11. A randomized trial of anticoagulants versus aspirin atter cerebral ischemia of presumed arlerial origin. The Stroke Prevention In Reversible Ischemia Trial (SPIRIT) Study Group. Ann Neurol 1997;42:857-865.

12. Poller L, Mckerman A, Thomson JM. Elstein M. Hirsch PJ, Jones JP. Fixed minidose wartarin: a new approach to prophylaxis against venous thrombosis after major surgery. Br Med J Clin Fes Ed 1987:295:1309-1312.

13. MacCallum PK. Thomson JM, Poller L. Ellecls of lixed minidose warlarin on coagulation and fibrinolysis following major gynaecological surgery. Thromb Haemost 1990;64:511-515.

14. Optimal oral anticoagulant herapy in patients with nonrheumatic atrial libriliation and recent cerebral ischemia. The European Atrial Fibrillation Triat Study Group. NEngl J Med 1995;333:5-10.

15. Randomised double-blind trial of fixed low.dose warlarin with aspirin atter myocardial intarction. Coumadin Aspirin Pentarction Study (CARS) Investigators. Lancet $1997,350,389-396$.

16. Lujckx GJ, Ukachoke C. Limapichat K. Heuss-van Raak EP. Lodoer J. Brain infarct causes under the age of fifty: a comparison between an east-Asian 
(Thai) and a western (Duch) hospital series. Ch Neurol Neurosurg $1993,95: 199-203$.

17. Dennis MS. Bamlord JM, Sandercock PA. Warlow CP. A companison of risk factors and prognosis for transient ischemic attacks and minor ischemic strokes. The Oxlordshire Community Stroke Protect. Stroke 198920:1494. 1499.

18. Hart RG, Miller VT. Cenebral infarction in young adults: a practical approach. Stroke 1983:14:110-114.

19. Adams H, J", Butler MJ. Biller J. Toffol GJ. Monhemorhagic cerebral infarction in young adults. Arch Neuro 1986;43:793-796.

20. Van de Berg JSP. Limburg M. Ischemic stroke in the young: influence of diagnostic criteria. Cerebrowasc Dis 1993;3:227-230.

21. Siqueira Ji, Santos AC, Fabio SRC, Sakamoto AC. Cerebral infarction in patients aged 15 to 40 years. Stroke 1996;27.2016-2019.

22. Kristensen B. Malm J, Carlberg B, Stegmayr B. Backman C, Fagerlund $M$, et al. Epidemiology and etiology of ischemic stroke in young adults aged 18 to 4.4 years in northern Sweden. Stroke 1997:28:1702-1709.

23. Luijckx G.. Boiten J, Lodder J. Heuls-van Raak L, Kessels F. Cardiac and carotid embolism, and other rare definite disorders are unlikely causes of lacunar ischaemic stroke in young palients. Cerebrovase Dis 1996;6:28-3:

24. Markus HS, Hambley H. Neurology and the blood: haematological abnomalities in ischaemic stroke. I Neurot Neurasurg Psychiairy $1998 ; 64: 150-159$

25. Munts AG, van Genderen Pul, Dippel DWJ, van Kooten F, Koudstaall PJ Coagulation disorders in young adults with acute cerebral ischaemia. If Neurol 1998;245:21:25.

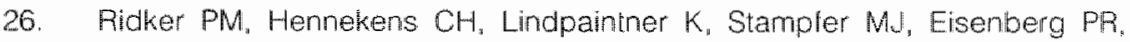
Miletich JP. Mutation in the gene coding for coagulation factor $V$ and the risk of myocardial infarction, stroke, and venous thrombosis in apparently healthy men. N Engl J Med 1995:332:912-917

27. Tosetto A, Ruggen M. Castaman G. Rodeghiero F. Inherited abnormalites ot blood coagulation in juvenile stroke a case control study. Brood Coagulation and Fibrimolysis 1997:3:397-402

28. Stomorken H, Sakariassen KS. Hemostatic risk lactors in arterial thrombosis and atherosclerosis: the thrombin-fibrin and plateletwWF axis. Thromb Res $1997 ; 89: 1-25$.

29. Sánchez J, Román J, Delatorre MJ, Velasco F, Torres A. Low prevalence of the lactor $V$ Leiden among patients with ischemic stroke. Haemostasis $1997: 27: 9-15$.

30. Halbmayer WM. Haushofer A, Angerer V. Finsiterer J. Fischer M. APC resistance and factor $V$ Leiden (FV $Q(506)$ ) mutation in patients with ischemic cerebral events. Blood Coagulation and Fibrinolysis 1997:8:361-364.

31. Siscovick DS, Schwartz SM, Rosendaal FR, Psaty BM. Thrombosis in the young: elfect of atherosclerolic risk factors on the risk of myocardial infarction associated with prothrombotic faclors. Thromb Haemost 1997; 78,7-12. 
Rosendaal FR, Siscovick DS, Schwartz SM. Beverly PK, Psaly BM, Longstrem WT, Jr. el al. Factor $V$ Leiden (resistance to activated protein C) increases the risk of myocardial intarction in young women. Blood 1997:89:2817-2821.

33. Kushner MJ. Prospective study of anticardiolipin antibodies in stroke. Stroke $1990: 21: 295-298$.

34. Hess DC, Krauss J Adams RJ. Nichols FT, Zhang D, Rountree HA. Anticardiolipin antibodies: a study of frequency in TIA and stroke. Neurology $1991: 41: 525-528$.

35. Chakravarty KK, Byron MA. Webley M, Durkin CJ, al-Hilawi AH, Bodley $R$, ell al. Antibodies to cardiolipin in stroke: association with montality and iunchonal recovery in patients without systemic lupus erythematosus. O $J \mathrm{Med}$ $1991: 79: 397-405$.

36. Nencini $P$, Baruffi MC, Abbate $R$, Massai G, Amaducci $L$, Inzitari D. Lupus anticoagulant and anticardiolipin antibodies in young adults with cerebral ischemia. Stroke 1992:23:189-193.

37. Coull BM, Levine SR, Brey RL. The role of antiphospholipid andibodies in stroke. Neurol Clin 1992; 10:125-143.

38. Anticardiolipin antibodies are an independent risk lactor for first ischemic stroke. The Antiphospholipid Antibodies in Stroke Study (APASS) Group. Neurology 1993;43:2069-2073.

39. Muir KW. Squire IB, Alwan W. Lees KR. Anticardiolipin antibodies in an unselected stroke population. Lancet 1994;34:4:452-456.

40. Schwartz SM, Siscovick DS, Longstreth WT, Psaly BM, Beverly AK. Raghunathan TE, et al. Use of low dose oral contraceptives and stroke in young women. Ann Intern Med 1997; 127:596-603

41. Heinemann LAJ, Lewis MA, Thorogood M. Spilzer WO. GuggenmoosHolzmann I, Bruppacher $\mathrm{P}_{n}$ et al. Case-control study of oral contraceptives and risk of thromboembolic stroke: results from intemational study on orat contraceptives and health of young women. BMU 1997,315:1502-1504.

42. Kither SJ, Stern BJ, Feeser BR, Hebel R, Nagey DA, Buchholz DW, at al. Pregnancy and the risk of stroke. N Engl J Med 1996:335:768-774.

43. Braltskrom L. Lindgren A, Israelsson B, Malinow MA, Norrving B. Upson B, el al. Hyperhomocystenaemia in stroke: prevalence, cause, and relationships to type of stroke and stroke risk factors. Eur J Clin invest 1992;22:214-221

44. Braltstróm LE. Hardebo JE. Hultberg BL. Moderate homocysteinemia possible risk factor for arteriosclerotic cerebrovascular disease. Stroke 1984:15:1012-1016.

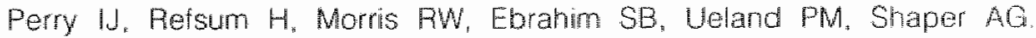
Prospective study of serum total homocysteine concentration and risk of stroke in middle-aged British men. Lancet 1995;346:1395-1398.

46. Fermo I, Vigano DAS, Paroni R. Mazzola G, Calor G. A. DA. Prevalence of moderate hyperhomocystenemia in patients with early-onset venous and arterial occlusive disease. Ann Intern Med 1995; 123:747-753.

Selhub J. Jacques PF, Bostom AG, D Agostino RB. Wison PW Belanger A. et al. Association between plasma homocysteine concentrations and 
extracranial carotidantery stenosis [see comments]. N Engl I Med $1995,332: 286-291$

48. Graham IM: Daly LE. Felsum HM, Pobinson K, Brattstrom LE. Ueland PM, at al. Plasma homocysteine as a risk factor for vascular disease: the European Concerted Action Project. JAMA 1997:277:1775-1781.

49. Hoogeveen EK, Kostense PJ, Beks PJ, Mackaay AJC, Jakobs C. Bouter LM, et al. Hyperhomocysteinemia is associated with an increased risk of cardiovascular disease, especially in noninsulin-dependent diabetes melitus. Arterioscier Thromb Vasc Biol 1998:18:133-138.

50. Clarke R, Daly L, Robinson K, Naughten E, Cahalane $S$. Fower $B$, et al Hyperhomocysteinemia: an independent risk factor for vascular disease. N Engl J Med 1991;3241149-1155.

51. Evans RW, Shaten BJ, Hempel JD, Cutler JA, Kuller LH. Homocyst(e)ine and risk of cardiovascular disease in the Multiple Risk Factor Intervention Trial. Arterioscler Thromb Vasc Biol 1997;17:1947-1953

52. Welch GN "Loscalzo J. Homocysteine and atherothrombosis. $N$ Engl J Med 1998;338:1042-1050.

53. Weksler BB. Hematologic disorders and ischemic stroke. Curr Opin Neurol $1995 ; 8: 38-44$.

54. Wood AJJ. Drugs and surgery in the prevention of ischemic stroke. N Engl J Med 1995;332:238-248.

55. Dyken ML, Bamett HJ, Easton JD. Fields WS, Fuster V, Hachinski V, el al. Low-dose aspirin and stroke. "It ain't necessarily so" [editorial]. Stroke 1992,23: $1395-1399$

56. Patrono $\mathrm{C}$, Roth $\mathrm{GJ}$. Aspirin in ischemic cerebrovascular disease. How strong is the case for a different dosing regimen? Stroke 1996:27:756-760

57. A comparison of two doses of aspirin ( $30 \mathrm{mg} v \mathrm{~s} .283 \mathrm{mg}$ a day) in patients after a transient ischemic attack or minor ischemic stroke. The Dutch TIA Trial Study Group. NEngl J Med 1991;325:1261-1266.

58. Millenson MM, Bauer KA Kistler JP, Barzegar $S$. Tulin L. Rosenberg RD Monitoring "mint-intensity" anticoagulation with wartarin comparison of the prothrombin lime using a sensitive thromboplastin with prothrombin fragment F1+2 levels. Blood 1992;79:2034-2038

59. Holm J. Berntorp E, Carisson R. Erhardt L. Low-dose wartarin decreases coagulability without affecting prothrombin complex activily. I Intern Med $1993,234: 303-308$

60. Maeda $N$. Seike $M$, Kume $S$, Takaku T, Shiga T. Fibrinogen-induced erythrocyte aggregation: erythrocyte binding site in the fibrinogen molecule. Biochim Biophys Acta 1987,904:81-91.

61. Chien S. Biophysical behavior of red cells in suspensions. 2 ed. New York: Academic Pres., 1975.

62. Guidelines on selection of laboratory tests for monitoring the acute phase response. International Committee for standardization in Haematology (Expert Panel on Blood Rheology). J Cim Pathol 1988,41:1203-1212. 
63. Maeda $N$. Sekiya M. Kameda K. Shiga T. Eflect of immunoglobulin preparations on the aggregation of human eythrocytes. Eur J Clin Invest $1986 ; 16: 184-191$.

64. Rosenblum WI. Asotsky RM. Factors altecting blood viscosity in macroglobulinemic mice. J Lab Clin Med 1968,71,201-211.

65. Baldwin JM, OReilly R. Whitney M, Lucy JA. Surtace exposure of phosphatidylserine is associated with the swelling and osmotically-induced fusion of human erythrocytes in the presence of Ca2+. Biochim Blophys Acta 1990; 1028:14 20.

66. Schroit AJ. Zwaal RF. Transbilayer movement of phospholipids in red cell and platelet membranes. Blochim Biophys Acta 1991:1071:313-329.

67. Rosenblum W. Asofsky RM. Malunction of cerebral microcirculation in macroglobulinemic mice. Relationship to increased blood viscosity. Arch Neuroi $1968 ; 18: 151-159$

68. Schmid-Schönbein H. Macrorheology and microrheology of blood in cerebrovascular insufliciency. Eur Neurol 1983:1 (22 Suppl):2-22.

69. Hayakawa M. Kuzuya F. Eflects of ticlopidine on erythrocyte aggregation in ihrombotic disorders. Angiology 1991:42:747-753.

70. Fisher $M$. Meiselman HJ. Hemorheological tactors in cerebral ischemia. Stroke 1991;22:1164-1169

71. Emsi Ex Resch KL, Matrai A, Buhl M, Schlosser P, Paulsen HF. Impaired blood theology: a risk tactor after stroke? J Intern Med 1991:229:457-462.

72. Somer T, Meiselman H.J. Disorders of blood viscosily. Amn Med 1993:25:3139.

73. Grotta J. Ackerman R. Correia J, Fallick G. Chang J. Whole blood viscosity parameters and cerebral blood flow. Stroke 1982:13:296-301

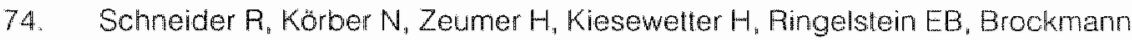
M. The haemorheological teatures of lacunar strokes. J Neurol 1985;232:357. 362.

75. Ernst E, Matrai A, Marshall M. Blood meology in palients with transient ischemic attacks. Stroke 1988; 19:634-636

76. Wong WH, Hu HH, Luk YO, Lo YK. The lollow-up sludy of blood viscosity in the palients with acute ischemic stroke. Ctim Hemorheol 1994; 14723-730.

77. Tanahashi $N$. Tomita $M$. Kobari M, Takeda $H$, Yokoyama M, Takao $M$, el al Platelet activation and erythrocyte aggregation rate in patients with cerebral intarction. Clin Hemorheol 1996-16:497-505.

78. Faber CG. Troost J, Vermes 1, Lodder J, Kalsbeek Batenturg EM, KesselsF, et al. Enhanced red blood cell aggregation unrelated to fibrinogen: a possible stroke mechanism in young patients. Cerebrovasc Dis 1997:7 70 76

79. Santos MT, valles J. Aznar J. Perez. Requejo JL. Role of red blood cells in the early stages of platelet activation by collagen. Thromb Haemosi 1986.56376 . 381.

80. Wood JH, Kee D. BJr. Hemorheology of the cerebral circulation in stroke Stroke 1985:16:765-772. 
81. Ona K. Fukuuchi $Y$, Tomita M. Tanahashi N. Malsuoka S, Takeda H Monocional antibody againgt platelet thrombospondin decreases erythrocyte aggregation rate. Biomeology 1991:28:551-556.

32. Hemker HC. Thrombin generation, an essental step in haemostasis and thrombosis In: Bloom AL, Fortes CD. Thoma DP. Tuddenham EGD, editors. Haemostasis and thrombosis. 3 ed. Edinburgh: Churchill Livingstone, $1994: 477-490$.

33. Rapapont S1. Introduction to hemalology. Second Edition ed. Philadelphia: J. Lippincoti Company, 1987

84. Vosso F. Prou-Wartelle $O$. Interaction of lissue factor and factor $W l l$ al the eariest phase of coagulation. Thromb Diath Haemorm Suppl 1965;17:35-44.

85. Dsterud B. Rapaport SI. Actiwation of 1251-factor $X$ and 125l-factor $X$ : elfect of tissive factor and factor VII, factor $\mathrm{Xa}$ and hrombin. Scand H Haematol $1980,24: 213 \cdot 226$

86. Xi M. Beguin S. Hemker HC. Importance of lactor-X-dependent prothrombinase formation-uthe Josso pathway-in clotting plasma. Haemostasis 1989;19:301-308.

87. Suzuki K. Dahlback B. Stentlo J. Thrombin-catalyzed activation of human coagulation factor $V$. J Biol Chem 1982;257:6556-6564.

88. Newcomb TF, Hoshida M. Factor $V$ and thrombin. Scand J Clin Lab Invest 1965:17 (Suppl 84)61-69.

89. Biggs F, MacFarlane RG, Denson KWE, Ash B. Thrombin and the interaction of Factors Vill and IX. Br J Haematoi 1965;11:276-295.

90. Rapaport SI. Schiman S. Patch MJ, Ames SB. The importance of activation of anthaemophilic globulin and proaccelerin by traces of thrombin in the generation of intrinsic prothrombinase activity. Blood 1963:21:221-236.

91. Bevers EM, Comfurius P. van Rijn JL. Hemker HC. Zwaal RF. Generation of prathrombin-converting activity and the exposure of phosphatidylserine at the outer surface of platelets. Eur J Biochem 1982,122,429-436.

92. Esmon CT. Protein C biochemistry, physiology, and clinicat implications Blood 1983,62:1155-1158

93. Rosing J. Tans $G$. Coagulation lactor $V$ an old star shines again. Thromb Haenost $1997 ; 78.427-433$

94. Rao LV, Rapaport S1. Studies of a mechanism inhibiting the initiation of the extrinsic pathway of coagulation. Blood 1987:69:645-651

95. Travis J. Salvesen GS. Human plasma protenase inhibitors. Amm Rev Brochem 1983;52:655 709 .

96. Hemker HC. Willems GM. Beguin S. A computer assisted method to obtain the prothrombin activation welocity in whole plasma independent of thrombin decay processes. Thromb Haemost 1986;56:9-17.

97. Beguin S. Thrombinoscopy. Thesis, Maastricht University, 1987

98. Kumar $\mathrm{B}$. Beguin S. Hemker $\mathrm{HC}$. The influence of fibrinogen and Hbrin on thrombin generation-evidence tor feedback activation of the clotting system by clat bound thrombin. Thromb Haemost 1994;72:713-T21. 
99. Bevers EM, Comfurius P. Zwaal RF. Platelet procoagulant activity: physiological significance and mechanisms of exposure. Blood Rev $1991 ; 5: 146-154$

100. Zwaal RF, Comfurius P. Bevers EM. Platelet procoagulant activity and microvesicle formation. Its putative role in hemostasis and thrombosis. Biochim Biophys Acta 1992;1180:1-8.

101. Waish PN, Camp E, Dende D. Different requirements for intrinsic lactor-Xa forming activity and platelet factor 3 activity and their relationship lo platelet aggregation and secretion. Br I Haemato/ 1978:40:311-331.

102. Sandberg H. Andersson LO. Hoglund S. Isolation and characterization of lipid-protein particles containing platelet factor 3 released from human platelets. Biochem $J$ 1982:203:303-311.

103. Sims PJ, Rollins SA. Wiedmer T. Regulatory control of complement on blood platelets. Modulation of platelet procoagulant responses by a membrane inhibitor of the C5b-9 complex. J Biol Chem 1989;264:19228-19235

104. Kumar R, Béguin S. Hemker HC. The effect of fibrin cllots and clot-bound thrombin on the development of platelet procoagulant activity. Thromb Haemost 1995;74:962-968.

105. Kumar R. On the procoagulant effect of fibrin. Thesis. Maastricht University, 1997

106. Blombäck B. Fibrinogen and fitorin-proteins with complex roles in hemostasis and thrombosis. Chr Hemorheot 1996; $16: 383-477$

107. Liu CY, Nossel HL, Kaplan KL. The binding of thrombin by fibrin. J Biot Chem $1979: 254: 10421-10425$.

103. Bennett JS, Vilatre G. Exposure of platelet fibrinogen receptors by ADP and epinephrine. J Clin hwest 1979;64:1393-140t.

109. Marguerie GA, PlOw EF, Edginglon TS. Human platelels possess an inducible and saturable receptor spectic for fibrinogen. J Biol Chem 1979;254:5357. 5363

110. Plow EF, Ginsberg MH. Speclic and salurable binding of plasma libronecin to thrombin-simulated human platelets. J Brol Chem 1981,256:9477-9482.

111. Berliner S. Nivya Ko Roberts JR, Houghten RA, Ruggeri ZM. Generation and characterization of peptide-specific antibodies that intibit von Willebrand factor binding to glycoprotein $/ \mathrm{b}$-lla without interacting with ollner acthesive molecules. Selectivity is conferred by Pro 1743 and other amino acid residues adjacent to the sequence Arg1744-Giv1745-Asp1746. I Biol Chem $1988: 263: 7500-7505$

112. Thiagarajan P. Kelly KL. Exposure of binding sites for vitronectin on platelets following stimulation. J Biol Chem 1988,263,3035-3038.

113. Pytela A. Pierschbacher MD, Ginsberg MH, Plow EF. Ruoslahti E. Platelet memorane glycoprotein Ilb/lla: member of a tamily of Arg-Gly-Asp-specilic adhesion receptors. Science 1986:231:1559-1562.

114. Wilhelmsen L, Svardsudd K, Korsan Bengtsen K, Larsson B, Welin L. Tibblin G. Fibrinogen as a risk lactor for stroke and myocardial inlarction. $N$ Engl $J$ Med 1984,311:501-505 
115. Kannes WB. Woll PA, Castell WP, OAgostino RB. Fibrinogen and risk of cardiowascular disease. The Framingham Study. JAMA 1987:258:1183-1186.

116. Qizlbash N, Jones $\mathrm{L}$. Warlow $C$. Mann J. Fibrinogen and lipid concentrations as risk tactors for transient ischaemic attacks and minor ischaemic strokes. BMJ 1991;303:605-609.

117. Yamell JW, Baker IA, Sweenam PM. Bainton D, O'Brien JR, Whitehead PJ, et all Fibrinogen, viscosity, and white blood cell count are major risk factors tor ischemic heart disease. The Caerphilly and Speedwell collaborative heart disease studies. Circulation 1991,83:836-84

118. Ernst $E$, Resch KL. Fibrinogen as a cardiovascular risk lactor: a metawanalysis and rewiew of the literature. Ann intern Med 1993:118:956-963.

119. Fowkes FG, Lowe GD. Housley E, Rathay A, Rumley A, Elton RA, et al. Cross. linked fibrin degradation products, progression of peripheral arterial disease. and risk of coronary heart disease. Lancet 1993;342:84-86.

120. Resch KL. Ernst E, Matrai A. Paulsen HF. Fibrinogen and viscosity as risk factors for subsequent cardiovascular events in stroke surviwors. Ann intem Med 1992:117:371-375.

121. Grotla JC, Yatsu FM. Pettigrew LC, Rhoades H, Bratina P. Vital D, et al. Prediction of carotid stenosis progression by lipid and hematologic measurements. Neurology 1989,39:1325-1331

122. Ensit E. Plasma fibrinogen an independent cardiowascular risk tactor. I Inten Med 1990:227:365*372.

123. Nobili F, Modriguez G, Marenco S, Gambaro M. Stubinski BM. Posadini $G$. Fibrinogen and cerebral blood flow: a correlative study. Chn Hemomeor $1993 ; 13: 245-252$

124. Smith EB. Thompson WD. Fibrin as a factor in atherogenesis. Thromo Res $1994 ; 73: 1-19$

125. Wagner D. Cell biology of won Willebrand tactor. Annu Rew Cell Biol $1990,6: 217-246$

126. Sakariassen KS, Bolhuis PA, Sixma JJ. Human blood platelel achesion to artery subendolhelim is mediated by factor Vlll. Von Willebrand factor bound to the subendothelium. Nature 1979,279.636-633.

127. Sikna J., Sakariassen KS. Stel HV, Houdik WP, In der Maur DW. Hamer PJ. et al. Functional domains on von Willebrand taclor. Recognition of discrete tryptic tragments by monoclonal antibodies that inhibit interaction of won Willebrand lactor with platelets and with collagen. J Chin invest 1984;74736744.

128. Meyer D, Girma JP. von Willebrand factor: structure and function. Thromb Haemos! 1993:70,99-104.

129. Weiss H.J. Tschopp TB, Baumgarner HA, Sussman, Il, Johnson MM, Egan Ju. Decreased adhesion of giant (Bemard-Soulier) plateleis lo subendothelium. Further implications on the role of the von Willebrand factor in hemostasis An J Med 1974:57:920-925.

130. Caen JP, Nurden AT, Jeanneau $G$ Michel H, Tobelem $G$, Levy-Toledano S, el at. Bernard-Soutier syndrome: a new platelel glycoprotein abnomality. Its 
relationship with platelet adhesion to subendothelum and with the lacior Vut von Willebrand protein. L Lab Cin Med 1976,87 586-596

131. Meyer D. Baumganner HR. Role of von Willebrand Factor in platelet adhesion to the subendothelium. Br J Haematol 1983;54:1-9

132. Weiss. H. Hawiger J, Ruggeri ZM, Turito VT. Thiagarajan P. Holtmann $T$ Fibrinogen-independent platelet adhesion and thrombus formation on subendothelum mediated by glycoprotein llb-llla complex at high shear rate. $J$ Cin inwest 1989:83:288-297.

133. Fuimolo T. Hawiger J. Adenosine diphosphale induces binding of von Willebrand factor to thuman platelels. Nature 1982;297:154-156.

134. Ruggeri ZM. De Marco L, Gathi L. Bader R, Mongomery RR. Piatelets have more than one binding site for von Willebrand factor. IChn Inwest 1983:72:112.

135. De Marco L, Girolami A, Zimmerman TS. Ruggeri ZM. von Willebrand lactor interaction with the glycoprotein IIb/lla complex. Its role in platelet function as demonstrated in patients with congenital afibrinogenemia. IChn Invest $1986 ; 77: 1272-1277$

136. Loscalzo $\rfloor_{\text {" Inbal }} \mathrm{A}_{*}$ Handin RI. von Willebrand protein facilitates platelet incorporation in polymerizing librin. J Clin huvest 1986; $78: 1112-1119$

137. Jen CU. Hu SJ, WU HJ, Lin TS, Mao CW. Platelet-fibrin interaction in the suspension and under flow conditions. Adv Exp Med Biol 1990;281:277-285.

138. Hantgan RR, Hindriks G. Taylor RG, Sixma JJ, de Groot PG. Glycoprotein Ib. von Willebrand factor, and glycoprotein Ilb/lla are all involved in platelet adhesion to fibrin in llowing whole blood. Blood 1990,76:345-353

139. Wang $Y$. [A study of plasma von Wilebrand factor concentration in patients with cerebrovascular disease]. Chung Hua Shen Ching Ching Shen Ko Tsa Chin 1992;25:106-108.

140. Kario K. Malsuo T, Kobayashi H. Asada R, Matsuo M. 'Sillent' cerebral infarction is associated with hypercoagulability, endothelial cell damage, and high Lpla) levels in elderly Japanese. Antrioscler Thromb Vaso Biol $1996: 16: 734-741$.

141. Blann AD. Endothelial cell damage and homocysteme [letter]. Atherosclerosis 1992,94:89:91

142. Blaes N, Plovella F, Samaden A, Boutherin Falson O. Ricetti M. Nicotine alers fibronectin and factor VIIJ/WF in human vascular endothelial colls. Br J Haematol 1986;64:675-687

143. Blann AD. Associations of von Willebrand lactor with age, sex and other risk factors for alherosclerosis. Thromb Haemost 1994,71:528-529.

144. Blann AD. McColtum CN. Adverse influence of cigarette smoking on the endothelum. Thromb Haemost 1993;70:707-711.

145. Blann AD. Naqwi T. Waite M. McCollum CN. von Willebrand lactor and endothelial damage in essential hypertension. J Hum Hyperiens 1993:7:107. 111

446. Blann AD, Daly RJ, Amiral J. The inlluence of age, gencer and ABO blood group on soluble endothelial cel markers and adhesion molecules. Br is Haematol 1996,92 498-500. 
147. Owren PA. The coagulation of blood. Investigations on a new clotting factor Acta Med Scand 1947:Suppl 194.

148. Biggs R. MacFarlane RG. Human blood coagulation and its disorders. Oxlord: Blackwell Scientific Publications, 1953

149. Hemker HC. Hemker PW, Torren Kvd, Devilée PP. Hermens WT, Loeliger EA The evaluation of the wo-stage prothrombin assay. Thromb Diath Haemorm $1971.25: 545-554$

150. Hemker $H C$. Wielders $S$, Kessels $H$, Beguin $S$. Continuous registration of thrombin generation in plasma, its use lor the determination of the thrombin polential. Thromb Haemost 1993,70:617-624.

151. Beguin $S$, Lindhout $T$, Hemker $H C$. The effect of trace amounts of tissue factor on thrombin generation in platelet rich plasma, its linhibition by heparin. Thromb Haemost 1989;61:25-29.

152. Kessels H, Béguin S. Andree $H_{*}$. Hemker HC. Measurement of thrombin generation in whole blood-the eftect of heparin and aspirin. Thromb Haemost 1994:72:78-83.

153. Kessels $H$, Willems $G$. Hemker HC. Analysis of thrombin generation in plasma. Comput Biol Med 1994:24:277-288.

154. Adams H, Jr., Kappelle LJ, Biller J, Gordon DL, Love BB, Gomez F, et al Ischemic stroke iny young adults. Experience in 329 patients enrolled in the lowa Registry of stroke in young adults. Arch Neurol 1995;52:491-495.

155. Boiten J, Lodder J. Lacunar infarcts. Pathogenesis and validity of the clinical syndromes. Stroke 1991;22:1374-1378.

156. Kiesewetter $H$. Radtke $H$, Schneider $\mathbb{R}$, Mussler $K$. Schetfler A SchmidSchombein $H$. [The mini-erythrocyte aggregometer: a new apparatus for the rapid quantification of the extent of erythrocyte aggregation]. Biomed Tech Berin 1982;27:209-213.

157. Schmid-Schönbein H, Mallota $H$, Striesow F. Eryhrocyte aggregation: causes, consequences and methods of assessment. Tijdsch Ned Ver Kin Chem 1990; 15:88-97.

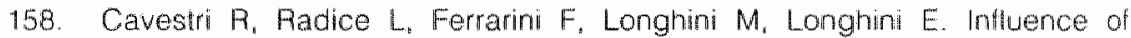
erythrocyte aggregability and plasma librinogen concentration on CBF with aging. Acta Neurol Scand 1992,85:292-298.

159. Shiga T. Maeda N. Kon K. Erythrocyte rheology. Crit Rev Oncol Hematol $1990: 10: 9-48$.

160. Wielders S, Mukherjee M, Michiels J, Rijkers DTS, Cambus JP, Knebel RWC. et al. The routine determination of the endogenous thrombin potential. first results in diferent forms of hyper-and hypocoagulability. Thromb Haemost $1997: 77: 629 \cdot 636$

161. Rolleveel RC, Roozendaal KJ. Eijsman L, Hemker HC. The influence of oral contraceptives on the time-inlegral of thrombin generation thrombin potential). Thromb Haenost 1993:70:959-962.

162. Rosing J. Tans G. Nicolaes GA. Thomassen MC, van Oerle $R$, wan der Ploeg PM, et al. Oral contraceptives and venous thrombosis. different sensitivities 10 activated protein $\mathrm{C}$ in women using second- and third gemeration oral contraceptives. Br J Haematol 1997:97:233-238. 
163. Dahlback B. Cartsson M. Svensson PJ. Familial thrombophila due to a previously unrecognized mechanism characterized by poor anticoaguant response lo activated protein C. prediction of a cofactor to activated protein? C. Proc Natl Acad Sci U S A 1993;90:1004-1008.

164. Dahback B. Molecular genetics of thrombophilia: factor $\mathrm{W} g e n e$ mutation causing resistance to activated protein $C$ as a basis of the hypercoagulable State. ILab Clin Med 1995-125:566-57 I

165. Rosendaal FR, Koster T, Vandenbroucke JP. Reitsma PH. High risk of thrombosis in patients homozygous for lactor $V$ Leiden (activated protein $\mathrm{C}$ resistance). Blood 1995;85:1504-1508.

166. Nicolaes GA, Thomassen MC. Tans G. Fosing J. Hemker HC. Ellecl of activated protein $C$ on thrombin generation and on the thrombin potential in plasma of nomal and APC-resistant individuals. Blood Coagulation and Fibrinolysis 1997;8:28-38.

167. Rijkers DTS, Wielders SJH, Ahenc-Gelas M, Bequin S, Hemker CH. The thrombomodulin ratio: A screening test for the protein $\mathrm{C}$ pathway. Thomb Haemos: 1997:77 (Suppl):2251

168. Rijkers DT, Wielders SJ, Tesser GI, Hemker HC. Design and synthesis of thrombin substrates with modified kinetic parameters. Thromb Res 1995:79:491 499.

169. Fisher M, Francis R. Altered coagulation in cerebral ischemia. Plalelet, thrombin, and plasmin activity. Arch Neurol 1990:47:1075-1079.

170. Nagayama M, Nagayama T, Ohnuki $Y$, Shinohara $Y$. Expanded spectrum of coagulopathy in the etiology of cerebral infarction in younger adulls in Japan: Comprehensive analysis of 77 patients. Cerebrowasc Dis 1996;6.350-355

171. Schaler Al. Hypercoagulable states: molecular genetics to clinical practice. Lancet 1994;344:1739-1742.

172. Koster $T$, Rosendaal FR, de Ronde H, Briel E, Vandenbroucke JP. Berlina FM. Venous thrombosis due to poor anticoagulant response to activated proten C: Leiden Thrombophilia Study. Lancet 1993,342:1503-1506.

173. Simioni $P$, de Ronde H. Prandoni P. Saladini M, Berlina FM, Girolami $A$. Ischemic stroke in young patients with activated protein $\mathrm{C}$ resistance. A report of three cases belonging to three different kindreds. Stroke $1995,26,885-890$

174. Koster T, Rosendaal FR. Activated proten C resistance in venous inrombosis. Lancel $1994,343.541$

175. D'Angelo A, Landi G, D'Angelo SV, Orazio EN, Boccardi E, Candelise L, el al Protein $C$ in acute stroke. Stroke $1988 ; 19579-583$.

176. Sacco RL, Owen J, Mohr JP. Tatemichi TK, Grossman BA. Free protein $S$ deficiency: a possible association with cerebrovascular occlusion. Stroke $1989 \cdot 20 \cdot 1657-1661$

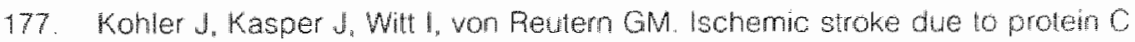
deficiency. Stroke 1990,21:1077-1080.

178. Matsushita K, Kuriyama $Y$, Sawada T, Uchida K. Cerebral inlarcion associalted with protein $C$ deliciency. Stroke 1992;23:108-111. 
179. Franken DG. Vreugdenfil A, Boers GH. Verrips A, Blom Hu, Novakova IR. Familial cerebroyascular accidents due to concomitant hyperhomocysteinemis and protein $C$ deficiency ype 1. Stroke $1993,241599-1600$.

180. Barinagarrementeria F, Cantú-Brito $C$, De La Peña $A$, Izaguirre $R$. Prothrombotic states in young people with idiopatric stroke. A prospective study. Stroke 1994;25:287-290.

181. Köller H, Stoll G, Sitzer M. Burk M. Schottier B. Freund HJ. Deficiency of both protein $C$ and protein $S$ in a lamily with ischemic strokes in young aduls Neurology $1994: 44: 1238-1240$.

182. Haberl RL, Biniasch O, OH M. Peinemanm A, Wick M, Kempter B. Infrequency of stroke caused by specific coagulation disorders. Cerebrovasc Dis $1995,5,391-396$.

183. Tatlisumak T, Fisher M. Hematologic disorders associated with ischemic stroke. J Nourol Sci 1996;1401-11

184. Bertina RM, Rosendaal FR. Venous thrombosis-The interaction of genes and environment. N Engl J Med 1998;338:1840-1841.

185. Heemskerk JWM. Sage SO Calcium signalling in platelets and other cells (review). Platelets 1994,5295-316

186. Brass LF. Manning DR. Clchowski $K$, Abrams CS. Signaling through $G$ proteins in platelets: to the integrins and beyond. Thromb Haemost 1997;78:581-589

487. Puri AN, Colman RW. ADP.induced platelet activation. Crit Rev Blochem Mol Biol 1997:32:437-502.

188. Andrews RK, López JA, Berndt MC. Molecular mechanisms of platelet adhesion and activation. Int J Biochem Cell Biol 1997:29:91-105.

189. Hylek EM, Skates Su, Sheehan MA, Singer DE. An analysis of the lowest effective intensity of prophylactic anticoagulation for patients with nontheumatic atrial fibrillation. N Eng/ / Med 1996;335:540-546.

190. Adjusted-dose warlarin versus low-intensily, fixed-dose wartarin plus aspirin for high-risk patients with atral fibrillation: Stroke Prevention in Atral Fibrillation III randomised clinical trial. Lancet 1996,348,633-638.

191. Szczeklik A, Krzanowski M. Gora P. Radwan J. Antiplatelet drugs and generation of thrombin in clotting blood. Blood 1992,80-2006-2011.

192. Musial J, Radwan J, Szczektlk A. Aspirin delays thrombin generation in wilro through interaction with platelet phospholipids. Thromb Res 1997:85:367378.

193. Owens MR, Cimino CD. The inhibitory eflects of sodium salicylate on synthesis of factor VII by the perlused rat liver. Thromb Res 1980:18:839-845.

194. Park BK, Leck JB. On the mechanism of salicylate-induced hypothrombinaemia. JPharm Phamacol 1981:33:25-28

195. Owens MR. Cimino CO. The interaction of salicylate and vitamin $K$ in synthesis of Factor II (prothrombin). Thromb Res 1983:31:135-143.

196. Hildebrandt EF, Suttie JW. The effects of salicylate on enzymes of vitamin $K$ metabolism. J Pharm Pharmacol 1983;35:421-426. 
197. Roncaglioni MC, Ulrich MM, Muler AD, Soute BA, de Boer-wan den Berg MA, Vermeer C. The vitamin K-antagonism of salicylate and warlarin. Thromb Res 1986:42:727-736

198. Schrör K. Antiplatelet drugs. A comparative review. Drugs 1995:50:7-28

199. Kistler JP, Singer DE. Millenson MM. Baver KA, Gress DR, Barzegar S, el al Effect of low-intensity warfarin anticoagulation on level of activily of the hemostatic system in patients with atrial fibrilation. BAATAF Investigators Siroke 1993:24:1360-1365

200. Falanga $A$, Levine $M N$, Consonni $R$, Griti $G$, Delaini $F$, Oldani E, et al. The effect of very-low-dose warfarin on markers of hypercoagulation in metastalic breast cancer: Resuls from a randomized trial. Thromb Haemost 1998; 79:23 27.

201. Smirnov MD, Esmon CT. Phosphatidylethanolamine incorporation into vesicles selectively enhances factor $\mathrm{Wa}$ inactivation by activaled protein $\mathrm{C}$.J Biol Chem 1994:269:816-819.

202. Azar AJ, Cannegieter SC. Deckers JW. Briët E, van Bergen PF. Janker Jd, el al. Optimal intensity of oral anticcagulant therapy after myocardial infarction. Am Coll Cardiol 1996;27:1349-1355.

203. Azar AJ, Koudstaal PJ, Wintzen AR, wan Bergen PlF, Jonker JJ, Deckers JW Risk of stroke during long-term anticoagulant therapy in patients after myocardial infarction. Ann Neurol 1996,39:301-30\%.

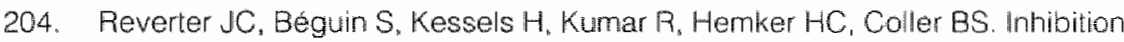
of platelet-mediated, tissue factor-induced thrombin generation by the mouse/human chimeric 7E3 antibody. Polential implications tor the effect of c7E3 Fab treatment on acute thrombosis and "clinical restenosis". J Clin Invest 1996;98:863-874.

205. Mari D, Mannucci PM, Coppola R; Bottasso B, Bauer KA, Rosenberg FD. Hypercoagulabilily in centenarians: the paradox of successful aging. Brood $1995 ; 85: 3144-3149$

206. Lodder J. Boiten J. Incidence, natural history, and risk factors in lacuinar infarction. Adv Neurol 1993:62:213-227.

207. Orme M. Aspirin all round? Br Med J Clin Res Ed 1988;296:307-B.

208. Peto R, Gray $A$, Collins R. Wheatley K, Hennekens $C$, Jamrozik $K$, et al Randomised trial of prophylactic daily aspirin in British male doctors. Br Med J Clin Res Ed 1988:296:313-6.

209. Final report on the aspirin component of the ongoing Pthysicians" Heath Study. Steering Commitlee of the Physicians" Health Study Research Group N Engl J Med 1989,32:129-35.

210. A randomised, blinded, trial of clopidogrel versus aspirin in patients at risk of ischaemic events (CAPRIE). CAPRIE Steering Committee Lancel $1996 ; 348: 1329-39$

211. Diener H. Cunha L. Forbes C. Sivenius J. Smels P. Lowenthal A. European Stroke Prevention Study 2. Dipyridamole and acelylsalicylic acid in the secondary prevention of stroke. J Neurol Sci 1996;143:1-13

212. Davis S. Donnan G. Secondary prevention lor siroke after CAPRIE and ESPS. 2. Cerebrovasc Dis 1998:8:73-77 
213. Inhibition of the platelet glycoprotein 1 b/llla receptor with trofiban in unstable angina and non-Q-wave myocardial intarction. The PAISM-PLUS Study Investigators. N Engl J Med 1998;338:1488-1497.

214. A comparison of aspirin plus tirotiban with aspirin plus heparin for unstable angina. The PRISM Study Investigators. N Engl J Med 1998;338:1498-1505

215. Schror K. Aspirin and platelets: the antiplatelet action of aspirin and its role in thrombosis treatment and prophylaxis. Semin Thromb Hemost 1997,23,349. 356 .

216. Kugelmass AD. Inhibitors of the platelet GP Ib-Hla tunction in the treatment of acute coronary syndromes. Curr Opin Hematol 1997:4:301-305. 


\section{Publications}

- Tobé TJM, de Langen CDJ, Crijns HJGM, Wiesteld ACP, van Gilst WH, Faber $\mathrm{CG}_{\text {, Lie } \mathrm{KI}}$, Wesseling $\mathrm{H}$.

Effects of streptokinase during acute myocardial infarction on the signal-averaged electrocardiogram and on the frequency of late arrhythmias.

Am J Cardiol 1993;72:647-651

- Tobé TJM, de Langen CDJ, Crijns HJGM, Wiesfeld ACP, van Gilst WH, Faber CG, Lie KI, Wesseling $\mathrm{H}$.

Late potentials, Qtc prolongation, and prediction of arrhythmic events after myocardial infarction.

Int J Cardiol 1994:46:121-128

- Faber CG, Boiten J, Cheriex EC.

Myxoma cordis.

CVA 1996:1:10

- Faber CG, Troost J, Vermes I, Lodder J, Kalsbeek-Batenburg EM, Kessels F, Haanen $C$.

Enhanced red blood cell aggregation unrelated to fibrinogen: a possible stroke mechanism in young stroke patients.

Cerebrovasc Dis 1997:7:70-76 
112 


\section{Dankwoord}

Bij een promotie staat de promovendus in hel midden van de belangstelling. Een proefschrift als dit zou er echter nooit zijn geweest zonder de hulp wan vele mensen. Met name wil ik hierbili bedanken:

Prof.dr. Jaap Troost, die mij vanaf de co-schappen tot aan dit proetschrift heeft begeleid. Bedankt voor alle mogelijkheden die je me hebl geboden, en voor de onvoorwaardelijke steun bij het verwezenlijken van mijn doelen.

Prof.dr. Coen Hemker, die de aanzet heeft gegeven tot een belangrijk deel van dit onderzoek. ledere onderzoeker komt "hobbels" tegen op weg naar het eindresultaat. De manier waarop en het gleduld waarmee voor ieder probleem een oplossing werd gezocht (en gevonden), hebben mij meer dan eens door een minder goed moment heen gesleept.

Suzette Béguin, die er een harde dobber aan heeft gehad om mij iels van de 'stolling' bij te brengen. Altijd stond je met raad en daad voor me klaar.

Jan Lodder, die altijd op hel juiste moment de motivatie erin weet te brengen en te houden. Zonder jouw inspiratie had dit boekje er nu zeker nog niet gelegen.

Natuurlijk de mensen van het 'lab': Simone Wielders en Khaled Marooli. voor de hulp bij alle bepalingen. Paul Devilée voor de assistentie bij alle TGT's en voor de vele kopjes thee. Carina van Zandvoort voor alle extra's "die er nog even iussendoor moesten.

Fons Kessels, woor zijn onontbeerlijke hulp bij de statistiek.

Alle patiënten die hebben meegewerkt aan dit onderzoek.

En natuurlijk Henk en Thomas, woor alle tijd die ze mij mel de compuler moesten delen. Hopelik breken nu betere tijden aan. 
14 


\section{Curriculum vitae}

Karin Faber werd geboren op 6 november 1965. In 1984 deed ze eindexamen WWO aan het Willem Lodewijk Gymnasium te Groningen. Hierna studeerde ze Geneeskunde aan de Rijksuniversiteit Groningen. In 1992 behaalde ze haar arts-examen, waarna ze direct is begonnen als assistent Neurologie in het Medisch Spectrum Twente, Enschede. Hier werd een aanvang gemaakt met het onderzoek dat uiteindelijk tot dit proefschrift heeft geleid. In 1993 kwam ze, aanvankelijk als AGNIO en later in opleiding, in dienst van het Academisch Ziekenhuis Maastricht (opleider Prof.dr. J. Troost). In Maastricht werd het onderzoek voortgezet onder leiding van Frof.dr. H.C. Hemker en Prof.dr. J. Troost. De opleiding Neurologie zal medio 2000 zijin algerond. 